Elementos estruturantes para a elaboração de políticas de direito autoral para repositórios institucionais de acesso aberto

DISSERTAÇÃO DE MESTRADO

Brasília

Outubro 2015 


\title{
Elementos estruturantes para a elaboração de políticas de direito autoral para repositórios institucionais de acesso aberto
}

\begin{abstract}
Dissertação de mestrado apresentada ao Programa de Pós-Graduação em Ciência da Informação (PPGCInf) da Universidade de Brasília (UnB), sob orientação da Profa. Dra. Sely Maria de Souza Costa.
\end{abstract}

Brasília

Outubro 2015 
Oliveira, Larissa Melo Bezerra de

Elementos estruturantes para a elaboração de política de direito autoral para repositórios institucionais de acesso aberto./ Larissa Melo Bezerra de Oliveira. - - Brasília:FCI/UnB, 2015 $125 \mathrm{f.} ; 30 \mathrm{~cm}$.

Dissertação apresentada à banca examinadora como requisito parcial à obtenção de título de mestre em Ciência da Informação pelo Programa de Pós-Graduação em Ciência da Informação da Faculdade de Ciência da Informação da Universidade de Brasília.

Orientador: Sely Maria de Souza Costa

Banca examinadora: Fernando César Lima Leite, Maria Carmen Romcy de Carvalho.

Bibliografia

1. Direito autoral 2.Políticas públicas 3. Acesso aberto. 4.Repositórios institucionais I. Título. 


\section{FOLHA DE APROVAÇÃO}

Título: "Elementos estruturantes para a elaboração de política de direito autoral para repositórios institucionais de acesso aberto".

Autor (a): Larissa Melo Bezerra de Oliveira

Área de concentração: Gestão da Informação

Linha de pesquisa: Comunicação e Mediação da Informação

Dissertação submetida à Comissão Examinadora designada pelo Colegiado do Programa de Pósgraduação em Ciência da Informação da Faculdade em Ciência da Informação da Universidade de Brasília como requisito parcial para obtenção do título de Mestre em Ciência da Informação.

Brasília, 30 de outubro de 2015.

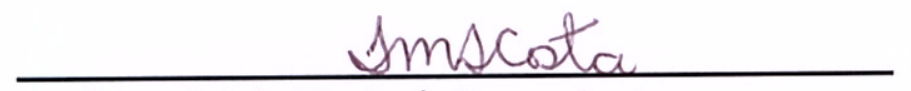

Prof. a Dr. - Sely Maria de Souza Costa

Presidente (UnB/PPGCINF)

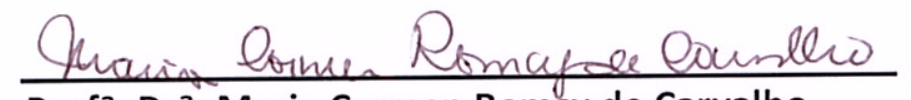

Profa. Dra. Maria Carmen Romcy de Carvalho

Membro Titular (IBCTI)

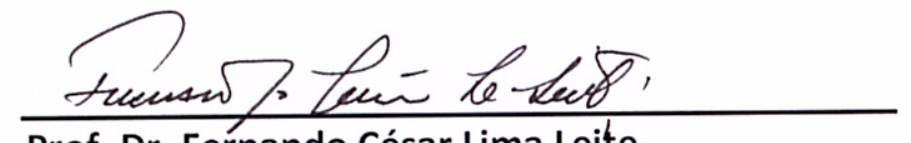

Prof. Dr. Fernando César Lima Leite

Membro Titular (UnB/PPGCINF)

Profa. Dra. Fernanda Passini Moreno

Membro Suplente (UnB/PPGCINF) 


\section{AGRADECIMENTOS}

Agradeço primeiramente a Deus por ter me agraciado com pais maravilhosos que se esforçaram ao máximo para que eu pudesse dedicar grande parte do meu tempo às minhas pesquisas. Agradeço em especial a minha mãe, pois sem ela eu nada seria.

Agradeço ao Wladimir, meu esposo, que se mostrou, além de um companheiro maravilhoso, um excelente e esforçado revisor e orientador de pesquisa.

Agradeço aos meus amigos e familiares, pelo apoio e compreensão de muitas ausências.

Agradeço à responsável pela construção deste trabalho, de outros que já foram publicados e de outros que ainda estão por vir. Agradeço a essa professora dedicada, estudante incansável, orientadora da vida profissional e, por vezes, pessoal. Agradeço pela parceria, pelas discussões criativas, pelas cobranças, pelas notícias, pelos cafés e pães de queijo. Obrigada, professora Doutora Sely Costa, por ter dedicado, a mim, o seu precioso tempo e a sua paciência!

Agradeço ao professor Doutor Paulo Du Pin Calmon por de me ensinar desde conceitos básicos de Ciência Política até teorias complexas capazes de explicar o Movimento do Acesso Aberto, tema alvo deste trabalho.

Agradeço ainda, ao professor Doutor Fernando, à Doutora Bianca Amaro e à Doutora Carmen Romcy por dividirem comigo um pouco do conhecimento que eles agregaram durante a brilhante carreira profissional que construíram ao longo dos anos.

E, por fim, mas não menos importante, agradeço à Rayanne e à Juliana Detoni, amigas de faculdade, pelo apoio e ilimitada capacidade de ajudar. 
"Imagine um mundo em que cada pessoa no planeta possua livre acesso à soma de todo o conhecimento humano."

Jimmy Wales 


\section{Resumo}

Apresenta elementos estruturantes de política de direito autoral para adoção por universidades, no que concerne a repositórios institucionais digitais. Discute, em sua fundamentação teórica, questões relacionadas à comunicação científica, o acesso aberto e os repositórios digitais institucionais, assim como ao direito autoral, no que diz respeito a conceitos, definições, legislações e regulamentações nacionais e internacionais. A metodologia do estudo utiliza a abordagem qualitativa por meio de procedimentos fundamentados em três técnicas de análise de texto, nomeadamente, condensação, categorização e interpretação. Tais procedimentos foram utilizados para análise de textos da literatura, de sites de repositórios e de entrevistas. Para tanto, foi analisada a literatura recente relevante sobre direito autoral, acrescida dos aspectos relacionados com o contexto do acesso aberto. Foram analisadas, ainda, informações obtidas a partir dos sites de repositórios de universidades brasileiras com registro no ROARMAP. Finalmente, foram analisados resultados obtidos por meio de entrevistas com gestores de repositórios insitucionais no Brasil, nos Estados Unidos e em Portugal, além de um especilaista no tema. Configura, desse modo, trabalho de caráter analítico descritivo. Apresenta, nesse contexto, abordagem inovadora no sentido em que inclui na discussão questões não consideradas em outros trabalhos, como a discussão e estudo da teoria da Advocacy Coalition Framework (ACF) para ilustrar a influência de coalizões políticas no avanço do Movimento do Acesso Aberto à literatura científica. Configura, ainda, um estudo de múltiplos casos enriquecido pela comparação com a literatura, o que permitiu concluir o trabalho com a apresentação de elementos que se configuram como estruturantes de política de direito autoral apropriada para ser adotada por repositórios institucionais de universidades no Brasil.

Palavras-chave: Direito autoral. Políticas públicas Acesso aberto. Repositórios institucionais. 


\begin{abstract}
The study presents structural elements of copyright policy to be adopted by universities and research institutes, regarding digital institutional repositories. It also discusses, as its theoretical basis, issues related to scientific communication, open access and institutional digital repositories, as well as the copyright concepts, definitions, legislation and national and international regulations. The study methodology uses a qualitative approach through procedures based on three text analysis techniques, namely, condensation, categorization and interpretation. Such procedures were applied for analysis of literature texts, repositories and interviews sites. To do so, the recent relevant literature on copyright, plus aspects related to the context of the open access were analyzed. The study also analyzed information obtained from the websites of Brazilian universities repositories with record in ROARMAP. Finally, results obtained were analyzed through interviews with institutional repositories managers in Brazil, in the United States and in Portugal, and another specialist in the matter. It sets thereby character descriptive analytical work. It presents, in this context, innovative approach in that includes a question not considered in other works' discussions, as the matter and study of Advocacy Coalition Framework (ACF) theory to illustrate the influence of political coalitions in the advance of the Open Access Movement to scientific literature. It also sets a multiple case study enriched by comparison with the literature, which allowed conclude the task with the presentation of elements that constitute appropriate copyright policy structure to be adopted by institutional repositories of universities and research institutes in Brazil.
\end{abstract}

Keywords: Copyright. Droit d'auteur. Open access policies. Institutional repositories. 


\section{LISTA DE FIGURAS}

Figura 1 - Interesses distintos de autores e editoras sobre o acesso aberto

Figura 2 - Modelo de Comunicação Científica de Hurd (2004)

Figura 3 - Princípios fundamentais da Convenção de Berna

Figura 4 - Vias verde e dourada para o acesso aberto

Figura 5 - Modelos de negociação de direitos autorais

Figura 6 - Políticas públicas e políticas governamentais

Figura 7 - Diagrama da ACF desenvolvido por Sabatier

Figura 8 - Políticas registradas por trimestre

Figura 9 - Número de políticas de acesso aberto no mundo (mandatória e nãomandatória)

Figura 10 - Modelo de comunicação científica de Hurd e o direito autoral

Figura 11 - Processo de formação de Política Institucional de Acesso Aberto no contexto do Direito Autoral à luz da ACF

Figura 12 - Linha cronológica da publicação das políticas institucionais

Figura 13 - Modelo conceitual da pesquisa 


\section{LISTA DE QUADROS}

Quadro 1 - Resumo da metodologia da pesquisa

Quadro 2 - Negociação para elaboração da política

Quadro 3 - Participação dos docentes na aprovação da política

Quadro 4 - Reação da comunidade acadêmica

Quadro 5 - Suporte oferecido pela universidade

Quadro 6 - Fatores que contribuem para o sucesso da política de direitos autorais 


\section{LISTA DE SIGLAS}

\begin{tabular}{|c|c|}
\hline ACF & Advocacy Coalition Framework \\
\hline COAPI & Coalition of Open Access Policy Institutions \\
\hline DRIVER & Digital Repositories Infrastructure Vision for European Research \\
\hline ECAD & Escritório Central de Arrecadação e Distribuição \\
\hline FURG & Fundação Universidade Federal do Rio Grande \\
\hline GATT & General Agreement on Tariffs and Trade \\
\hline $\mathrm{IBICT}$ & Instituto Brasileiro de Informação, Ciência e Tecnologia \\
\hline IBPI & Instituto Brasileiro de Propriedade Intelectual \\
\hline IDEC & Instituto Brasileiro de Defesa do Consumidor \\
\hline JISC & Joint Information Systems Committe \\
\hline LDA & Lei de Direitos Autorais \\
\hline OAI & Open Archives Initiative \\
\hline OIT & Organização Internacional do Trabalho \\
\hline OMC & Organização Mundial do Comércio \\
\hline OMPI & Organização Mundial da Propriedade Intelectual \\
\hline ONU & Organização das Nações Unidas \\
\hline $\mathrm{RI}$ & Repositório Institucional \\
\hline ROARMAP & Registry of Open Access Repository Mandates and Policies \\
\hline SGAE & Sociedade Geral de Autores e Editores \\
\hline SIAE & Sociedade Italiana dos Autores e Editores \\
\hline SNEL & Sindicato Nacional dos Editores de Livros \\
\hline SPARC & Scholarly Publishing and Academic Resources Coalition \\
\hline TRIPS & Agreement on Trade-Related Aspects of Intellectual Property Rights \\
\hline UnB & Universidade de Brasília \\
\hline USP & Universidade de São Paulo \\
\hline UNESCO & Organização das Nações Unidas para a Educação, a Ciência e a Cultura \\
\hline UFBA & Universidade Federal da Bahia \\
\hline UFCE & Universidade Federal do Ceará \\
\hline UFLA & Universidade Federal de Lavras \\
\hline UFOP & Universidade Federal de Ouro Preto \\
\hline UFRB & Universidade Federal do Recôncavo da Bahia \\
\hline UFRN & Universidade Federal do Rio Grande do Norte \\
\hline UFRGS & Universidade Federal do Rio Grande do Sul \\
\hline UFS & Universidade Federal de Sergipe \\
\hline
\end{tabular}




\section{SUMÁRIO}

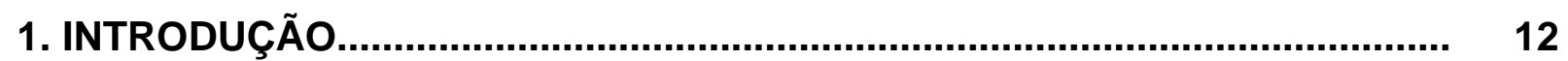

1.1 Contextualização do problema........................................................... 12

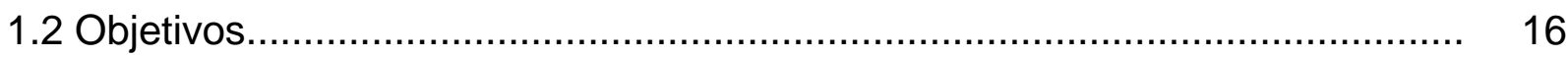

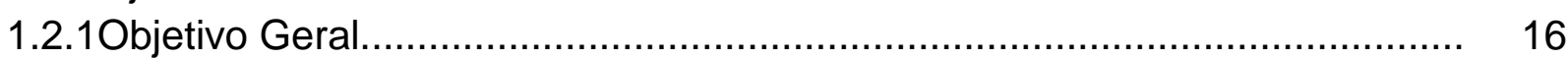

1.2.2 Objetivos Específicos......................................................................... 16

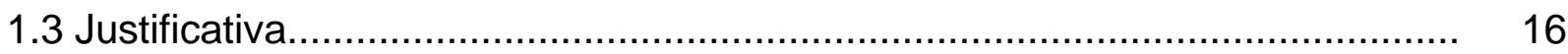

2. FUNDAMENTAÇÃO TEÓRICA DA PESQUISA......................................... 19

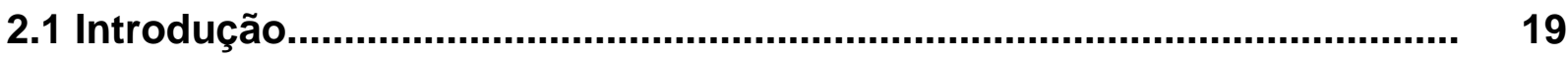

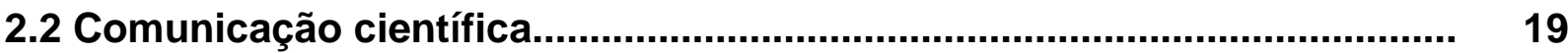

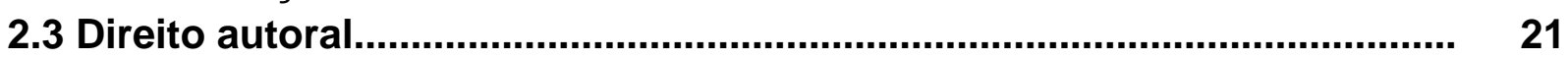

2.3.1 Aspectos históricos do direito autoral................................................. 21

2.3.2 Acordos e tratados internacionais............................................................. 24

Convenção de Berna................................................................................ 24

Convenção Universal sobre o direito de autor (Convenção de Genebra)............. 25

Convenção de Roma............................................................................ 27

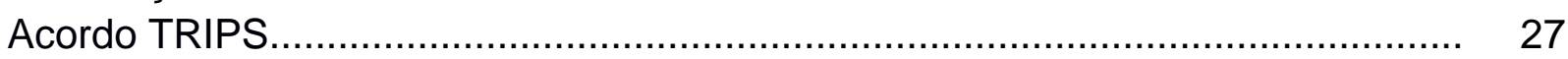

Tratado OMPI (WIPO) sobre direito autoral................................................... 29

2.3.3 Direito de autor (Droit d'auteur) versus Copyright................................... 30

2.3.4 Direito autoral no Brasil............................................................................. 32

2.3.5 Direito autoral nos Estados Unidos......................................................... 36

2.3.6 Direito autoral na Europa.................................................................. 40

2.3.7 Limitações ao direito autoral ................................................................... 39

2.3.8 Transferência dos direitos autorais: direito moral e direito patrimonial........ 42

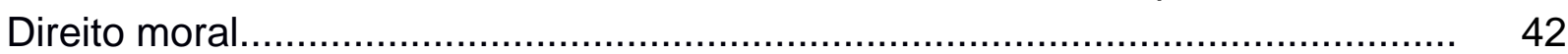

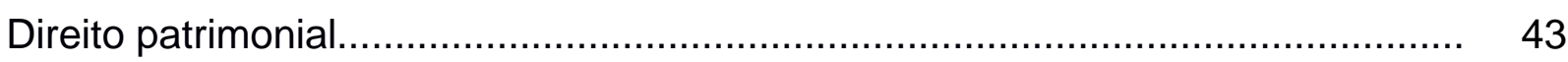

2.40 direito autoral no acesso aberto à literatura científica.......................... 45

2.4.1 $\mathrm{O}$ acesso aberto à literatura científica......................................................... 45

2.4.2 Repositórios institucionais de acesso aberto (Via Verde)........................... 47

2.4.3 Direito autoral: copyleft e creative commons................................ 49

Licença copyleft................................................................... 50

Creative Commons.......................................................... 51

2.5 Política pública de acesso aberto à literatura científica........................... 53

2.5.1 Advocacy Coalition Framework (ACF)................................................ 57

2.5.2 Coalizões: o contexto do acesso aberto................................................ 60

Scholarly Publishing and Academic Resources Coalition (SPARC)............... 60

Coalition of Open Access Policy Institutions (COAPI)............................. 61

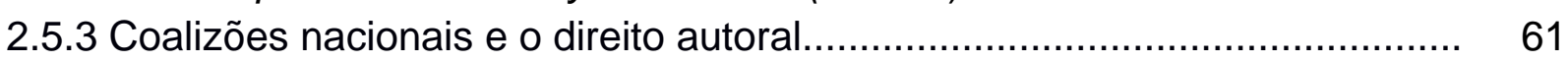

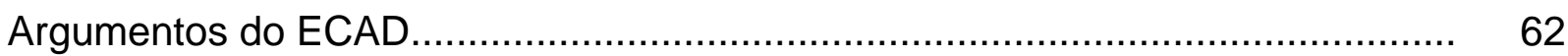

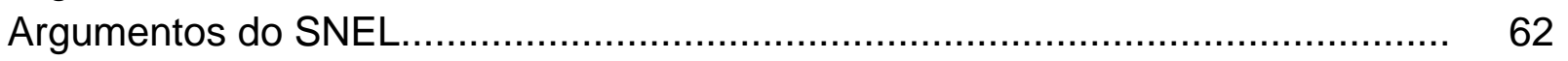

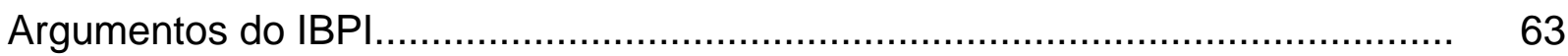

Coalizão da Rede pela Reforma................................................................. 63

2.5.4 Política Institucional de Acesso Aberto.......................................................... 64 
2.5.5 Políticas institucionais à luz do direito administrativo: o ato administrativo... 70

2.5.6 Projeto de Lei 387/2011: a reforma que não acontece........................... 74

3. METODOLOGIA...................................................................................... 78

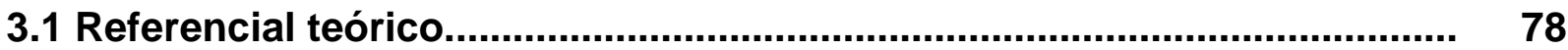

3.1.1 Conceitos da pesquisa............................................................... 78

3.2 Plano da pesquisa.................................................................................. 80

3.2.1 Abordagem, método da pesquisa e instrumentos de coleta de dados......... 80

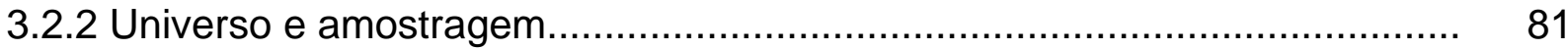

3.2.3 Técnicas de análise dos dados................................................... 82

4. ANÁLISE E DISCUSSÃO DOS RESULTADOS....................................... 85

4.1 Introdução.............................................................................................. $\quad 85$

4.2 Questões teóricas e legais.................................................................... 85

4.2.1 A comunicação científica no acesso aberto e o direito autoral.................... 86

4.2.2 Formação de política pública no contexto do acesso aberto...................... 90

4.2.3 Limitação ao ordenamento jurídico brasileiro e formação de política de $\quad 91$

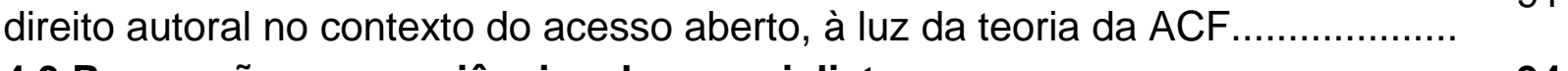

4.3 Percepções e experiências de especialistas.......................................... 94

4.4 Políticas dos repositórios....................................................................... 104

4.5 Modelo conceitual resultante da pesquisa.............................................. 109

5. CONCLUSÃO........................................................................................ 112

5.1 Introdução............................................................................................ 112

5.2 Elementos estruturantes para políticas institucionais de direito autoral. 112

5.3 Questões relevantes da fundamentação teórica...................................... 112

5.3.1 Processo de comunicação científica ........................................................... 112

5.3.2 Direito autoral............................................................................ 113

5.4 Políticas institucionais de acesso aberto............................................... 113

5.4.1 Negociação na elaboração da política................................................ 113

5.4.2 Participação dos docentes na elaboração da política.............................. 114

5.4.3 Reação da comunidade acadêmica ao depósito compulsório..................... 114

5.4.4 Apoio aos autores...................................................................... 114

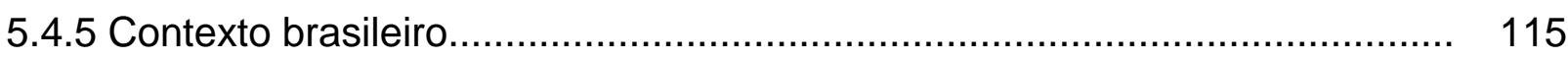

5.5 Elementos necessários à política .......................................................... 115

5.6 Contribuições do estudo...................................................................... 115

5.7 Sugestões para estudos futuros......................................................... 116

6. REFERÊNCIAS................................................................................... 117

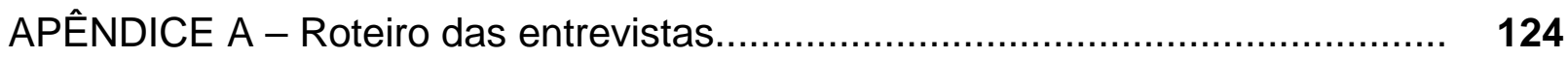

APÊNDICE B - Instituições selecionadas no ROARMAP ............................. 125 


\section{INTRODUÇÃO}

\subsection{Contextualização do problema}

Uma nova tendência de publicações de periódicos surgiu após a crise decorrente do encarecimento das suas assinaturas, o que os tornou pouco acessíveis à comunidade científica, em particular, e a sociedade em geral. Esse processo desencadeou discussões no meio acadêmico, proporcionando nova visão para a comunicação científica e inovando a forma de disseminação de resultados de pesquisa. Desse modo, deu-se origem ao assim chamado movimento em favor do acesso aberto à informação científica, o qual se tornou um assunto instigante e muito debatido em diferentes áreas do conhecimento, incluindo a Ciência da Informação. A discussão dá-se mais acaloradamente devido ao sucesso da iniciativa, que envolve todos os agentes responsáveis pelo processo de comunicação da ciência.

Nesse contexto, uma questão que tem debate ainda mais acalorado e que, de fato, é central nessas discussões, é o direito autoral. Sabe-se que se tem travado um verdadeiro cabo de guerra (figura 1 ) entre autores e editores sobre essa questão. Isso porque o movimento vai de encontro aos interesses das editoras, visto que tem sido por elas interpretado como podendo diminuir seus lucros exacerbados. Tais lucros, por sua vez, são resultado dos modelos de negócio de cada uma, os quais são inteiramente baseados nas assinaturas de seus periódicos.

As assinaturas, por sua vez, refletem não somente a política de detenção dos direitos de autor e dos direitos de cópia pelos editores, como também autores que preferem publicar em periódicos de alta importância e maior avaliação visando o prestígio e maior número de citações. O que acaba restringindo exacerbadamente o acesso a seus conteúdos, na medida em que só tem acesso quem pode pagar pelas assinaturas.

No que concerne aos autores, suas recompensas e a moeda com que trabalham é o reconhecimento pela comunidade científica, primeiramente, e pela sociedade, em última instância. Em outras palavras, o interesse dos autores é a disponibilidade ampla de seus resultados, a acessibilidade irrestrita a suas 
publicações e a visibilidade resultante do reconhecimento do valor destas, isto é, o impacto de suas pesquisas.

Figura 2 - Interesses distintos de autores e editoras sobre o acesso aberto

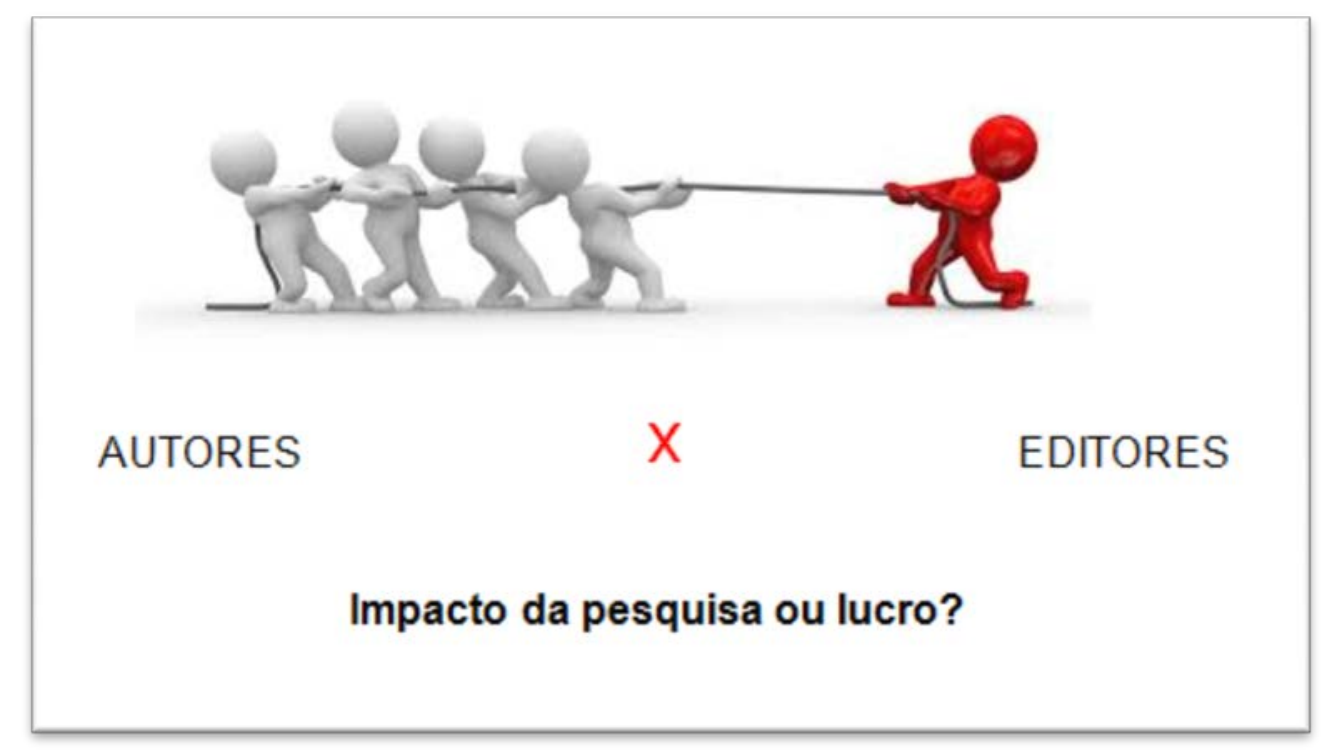

Fonte: adaptado a partir de Portal da Nutricionista ${ }^{1}$

Diante desse tipo de conflito, bibliotecas de universidades podem exercer papel de mediadores das negociações entre editores e autores. Para tanto, é necessário que realizem pelo menos quatro tipos de ação, nomeadamente:

- Elaboração de políticas de informação no contexto do acesso aberto, no âmbito de suas instituições;

- $\quad$ Orientação a autores (pesquisadores de suas instituições) com relação a licenças de uso de sua produção científica;

- $\quad$ Controle de publicações cujo acesso nos repositórios de suas instituições é embargado;

- $\quad$ Garantia de observação dos diversos tipos de licenças de uso.

\footnotetext{
${ }^{1}$ Disponível em: http://portaldanutricionista.blogspot.com.br/2015/08/alimento-e-diferente-decomida-voce.html
} 
É necessário observar que tais etapas não resolvem diretamente a problemática dos direitos autorais. Entretanto, constituem caminhos para chegar a soluções que acomodem os interesses tanto de pesquisadores quanto de editores e até mesmo de usuários da informação.

Tal transformação nos papéis exercidos por bibliotecários de instituições acadêmicas, cujos trabalhos em equipes multidisciplinares que incluam profissional especialista em direito autoral, tem sido comum em países que estimulam e incentivam o Acesso Aberto. É o caso, por exemplo, do Escritório de Negociação da Universidade de Harvard, nos Estados Unidos.

É importante destacar que o estímulo ao acesso aberto à informação científica dá-se tanto por meio da comunidade científica quanto por meio da adoção pelo Estado de políticas de informação que favoreçam a disseminação e a democratização do acesso à informação científica. Apesar de o Movimento do Acesso Aberto comprovadamente elevar os índices de acessibilidade à informação científica no mundo, ainda existem dificuldades com relação às políticas públicas de informação - incluindo as legislações de Direitos Autorais - em alguns países.

De fato, governos de diversos países, como por exemplo, Reino Unido, Austrália, Estados Unidos, e a própria Comunidade Europeia, já reconheceram a importância de se abordar o tema, inclusive com a realização de reuniões para discussão e assinatura de acordos que garantam a proteção mútua aos direitos do autor. O marco importante que deu início a essas discussões e decisões no âmbito de tratados de Direitos Autorais é a Convenção de Berna, fruto da terceira conferência diplomática sobre direitos autorais, que estabeleceu o reconhecimento do direito de autor entre nações soberanas.

A Convenção de Berna tem, na verdade, sido modelo para a legislação de todos os países signatários, inclusive o Brasil. Entretanto, o acesso aberto no Brasil ainda carece de um marco normativo/institucional para poder, além de regulamentálo, incentivar sua adoção pela comunidade acadêmica de forma mais abrangente. Isso porque o país não dispõe de uma política de informação e a Lei 9.610/98, atual legislação de direitos de autorais, não se mostra como o instrumento indicado para 
tanto. Cabe, portanto, às instituições acadêmicas tomarem providências para melhorar a retenção e disponibilização da propriedade intelectual produzida pela comunidade científica. Já é notório o interesse de universidades brasileiras em aderir o Acesso Aberto no seio da comunicação científica.

Por vezes, contudo, esse processo é questionado em razão da falta de orientações com relação às dimensões legal, institucional e tecnológica de uma política de informação para repositórios institucionais, e que, geralmente, carece dos aspectos próprios da política de direitos autorais. Estudos e relatórios que verificam o avanço do Acesso Aberto no mundo e no Brasil sugerem que a política de informação de uma Instituição é fundamental para o seu desenvolvimento, como destacado por Oliveira (2011).

Independentemente dessas carências, a quantidade de políticas de regulação dos repositórios institucionais tem aumentado. A quase totalidade segue a tendência orientadora da Declaração de Berlim (2003), cujo conteúdo tem servido de modelo para essas políticas. Entretanto, é possível verificar falhas com relação a conceitos, obrigações, direitos, conteúdo, competência e forma no que diz respeito aos Direitos Autorais. Isso contribui substancialmente para a invalidação dos efeitos do Movimento do Acesso Aberto baseado na questão do depósito compulsório e questões afins.

Como observa Strassmann (1994), a política não é apenas o caminho para exercer autoridade, mas também a arte de alcançar o consenso corporativo. $\mathrm{Na}$ verdade, a literatura tem demonstrado que não basta uma política regulatória para garantir a adesão da comunidade científica (XIA et al, 2012) à assim chamada filosofia do Acesso Aberto. O que parece imprescindível é uma política de incentivo para engrenar o Movimento e, com isso, criar uma nova cultura entre produtores e usuários de conhecimento científico. Nessa perspectiva, o objetivo da presente pesquisa é de, ao final do estudo, responder a seguinte pergunta:

Considerando o contexto do acesso aberto ao conhecimento científico e a legislação brasileira de direitos autorais, quais os elementos necessários à 
elaboração de uma política de direito autoral apropriada para adoção por repositórios institucionais de universidades brasileiras?

A resposta a esta pergunta é possível por meio do que estabelecem os objetivos específicos da pesquisa. Estes, por seu turno, além de apontarem caminhos, auxiliam no alcance do objetivo geral, como mostrado a seguir.

\subsection{Objetivos}

\subsubsection{Objetivo Geral}

Identificar elementos estruturantes para a elaboração de uma política de direito autoral no contexto do acesso aberto que norteie as ações em universidades, no que concerne a repositórios institucionais.

\subsubsection{Objetivos Específicos}

- Descrever questões que fundamentam a discussão sobre o direito autoral no contexto do acesso aberto à literatura científica;

- Analisar elementos de políticas institucionais, com relação aos direitos autorais, para repositórios digitais de acesso aberto;

- Identificar elementos necessários à elaboração de políticas efetivas de direito autoral para repositórios digitais de acesso aberto.

\subsection{Justificativa}

Embora o movimento em favor do acesso aberto à informação científica tenha alcançado números expressivos de depósitos em repositórios de acesso aberto com o avanço da tecnologia, as políticas tem sido uma questão bastante discutida na comunidade científica que pesquisa o assunto. Isso porque o acesso aberto está intrinsecamente relacionado com o Direito de Autor, que é o responsável pelo gargalo dessas políticas, pois é ele o moderador que regula o quão livre será o acesso à produção científica. 
De fato, é o direito autoral que se apresenta como uma das grandes preocupações para o avanço do Movimento do Acesso Aberto. Diferentemente da tecnologia, cujos avanços são contínuos e dinâmicos, o direito autoral depende da política informacional e, consequentemente, da legislação adotada em cada nação. Observa-se, em algumas nações a utilização do uso justo da obra (fair use) em certas ocasiões, o que tende a se constituir em um aspecto de evolução da política informacional. Reformas legais e políticas são, portanto, fundamentais para estruturar um cenário favorável ao desenvolvimento do Movimento do Acesso Aberto.

Ocorre que a falta de conhecimento técnico na área de direitos autorais gera insegurança jurídica nos envolvidos no processo da disponibilização do conteúdo científico em repositório institucional de acesso aberto. Além disso, gestores tendem a replicar modelos de sucesso com a adoção de políticas internacionais de informação de repositórios institucionais. Todavia, levando-se em conta que parte do conteúdo dessas políticas trata diretamente dos direitos autorais, essa replicação pode ser danosa, em razão da possibilidade de ir de encontro ao ordenamento jurídico. Isto é, promover infração legal, o que acaba por impedir o desenvolvimento seguro e sustentável do acesso aberto à informação científica no país

Vale a pena destacar ainda que, embora no cenário mundial haja bons resultados com políticas de direitos autorais eficientes, o Brasil tem uma das piores legislações de direito autoral, se considerados aspectos relativos ao acesso ao conhecimento. Esse dado foi levantado, em 2009, 2010, 2011 e 2012, pela Consumers International, federação que congrega entidades de defesa do consumidor de todo o mundo. O relatório de 2012, que pode ser acessado em http://a2knetwork.org/consumers-international-ip-watchlist-report-2012 retrata essa situação

A situação da lei de direitos autorais no Brasil, em comparação com alista de 2011 da IP, é o mesmo, no que se refere ao texto do projeto e disposições. A diferença é o fato de que as chances de o processo de reforma Lei de Direitos Autorais para ser concluído são menores do que nos últimos anos. O Ministério da Cultura, que é encarregado de liderar este processo, tem um entendimento diferente da necessidade de adaptar a Lei $n^{\circ} 9.610 / 98$. Hoje, o projeto de lei 
está estagnado pela falta de consenso entre os Ministérios do próprio governo. No entanto, a sociedade civil continua a pressão por reforma. (Grifo nosso)

O relatório chama a atenção pelo fato de incluir a falta de consenso entre as entidades governamentais como uma das causas para o enquadramento retrógrado do Brasil, no contexto internacional, no que diz respeito à legislação de direitos autorais.

É neste cenário que se insere o presente trabalho, que visa a contribuir não somente para o enriquecimento dessas discussões, mas também, e principalmente, para apresentar, com base na análise da literatura, de políticas existentes e da visão de especialistas, elementos necessários à estruturação de uma política de direito autoral para repositórios institucionais. Do ponto de vista teórico, o trabalho visa a contribuir dando ênfase à questão da importância das coalizões para o avanço do acesso aberto, no que concerne aos direitos autorais. Do ponto de vista prático, o trabalho visa a contribuir, no contexto brasileiro, para o êxito na implementação de suas políticas de informação para repositórios institucionais no que concerne aos direitos autorais. 


\section{FUNDAMENTAÇÃO TEÓRICA DA PESQUISA}

\subsection{Introdução}

Visando a apresentar panorama teórico das questões que fundamentam o presente estudo, este capítulo envolve a discussão, com base na literatura, de questões relacionadas com dois grandes tópicos. O primeiro, a comunicação científica, discutido sucintamente com base no modelo de comunicação de Hurd (2004). O segundo, o direito autoral, discutido desde questões históricas, passando pelas legislações atuais e vigentes em diferentes países e chegando aos aspectos relacionados ao contexto do acesso aberto e dos repositórios institucionais.

\subsection{Comunicação científica}

Garvey e Griffith (1979, p.128) definem a comunicação científica como um conjunto de atividades ligadas à produção, disseminação e uso da informação, desde o momento em que o pesquisador define o tema da pesquisa até o instante em que o resultado é aceito como parte do conhecimento universal. Os autores acrescentam que a produção literária envolve uma série de atividades de comunicação entre os pesquisadores, algumas prévias - identificação do problema, por exemplo - e outras posteriores à publicação - assimilação do conhecimento pelo beneficiário final (GARVEY; GRIFFITH, 1967, p. 123). São notáveis as mudanças observadas no processo - e nos modelos que o ilustram - desde então. São, igualmente, inúmeros os modelos que ilustram o processo de comunicação científica, encontrados na literatura, desde o modelo seminal de Garvey (1979). Levando-se em conta que abundam na literatura tais modelos, destaca-se, no presente trabalho, o modelo mais recente de Hurd (2004), por ilustrar o processo de modo a facilitar a inserção dos aspectos relacionados aos direitos autorais.

Uma autora que tem se destacado, desde meados da década de 1990 é Julie Hurd, a qual vem adequando seus modelos de comunicação científica de acordo com os avanços tecnológicos e com novos padrões identificados no seio da comunidade científica. Em seu modelo mais recente, Hurd (2004) ilustra o processo 
de comunicação científica (figura 2) com base nas mudanças introduzidas pelo movimento do acesso aberto. Observe-se que todas as etapas do processo ilustradas em elipses são inovações decorrentes de avanços tecnológicos. Por outro lado, externamente às figuras (retângulos e elipses) a autora destaca as mudanças nos papeis dos principais atores do sistema de comunicação científica.

Figura 2 - Modelo de Comunicação Científica de Hurd (2004)

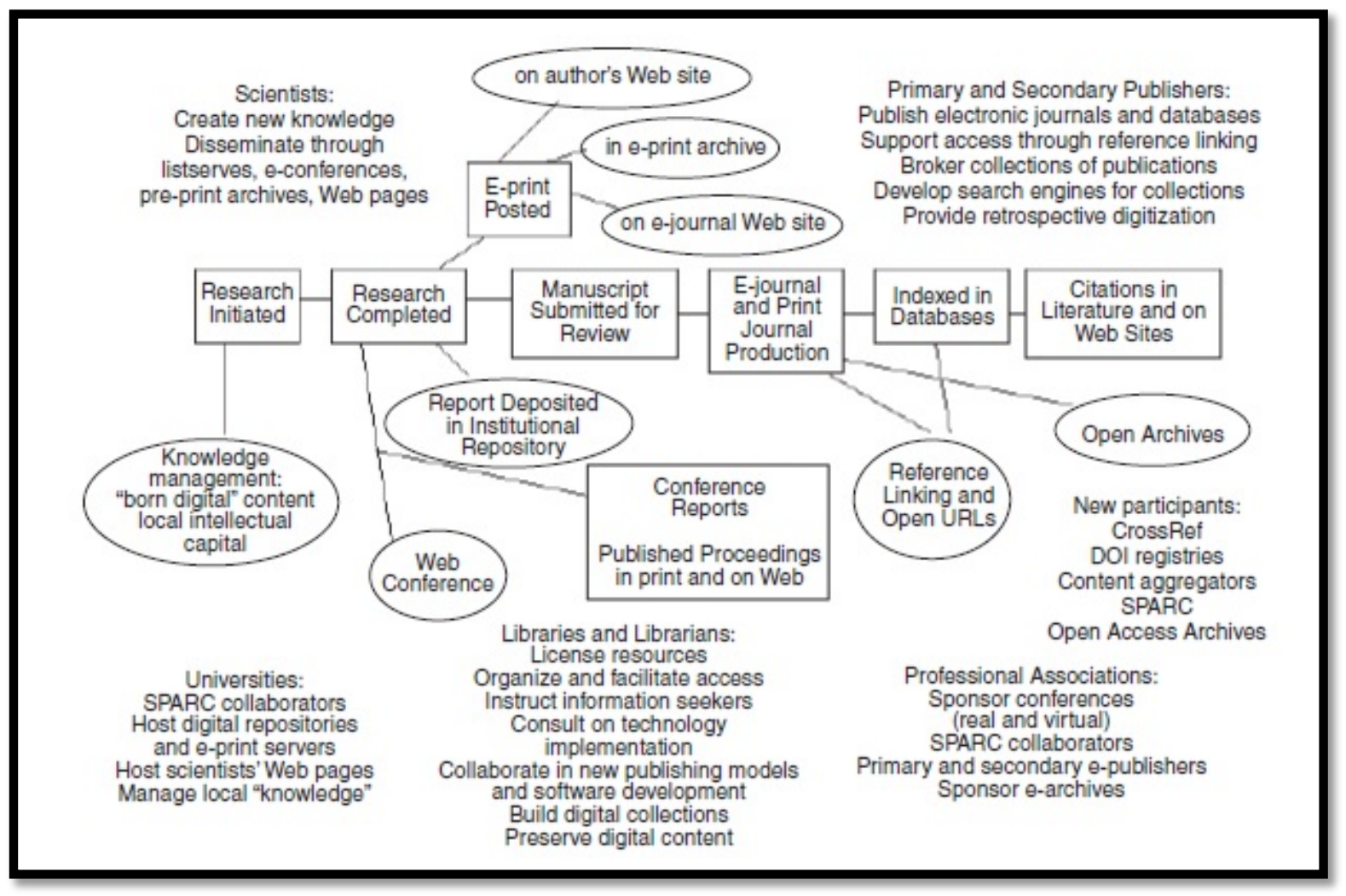

Fonte: HURD, Julie M.(2004, p.14).

Diferentemente do modelo de Garvey \& Griffith, a nova ótica proposta por Hurd (2004, p.10), apesar de ser baseada na mesma linha de evolução, fundamenta-se inteiramente na comunicação eletrônica,

com cientistas promovendo o intercâmbio de dados e consultando recursos de uma biblioteca digital, interagindo através de grandes distâncias tão facilmente como se estivessem compartilhando a mesma instalação física. O sistema de CC, nesse caso, prevalece no ambiente colaborativo, onde os "dados" são as "unidades de troca de informações". (Tradução nossa) 
Conforme pode ser verificado, as diversas questões relacionadas à comunicação científica levam à apresentação de elementos novos que surgem no contexto da pesquisa. Consequentemente, requerem a apresentação de novos elementos que ganham destaque e integram a dinâmica da comunicação científica atual. É o caso do direito autoral, especialmente no que diz respeito a mudanças introduzidas pelo acesso aberto, questões que são discutidas a seguir.

\subsection{Direito autoral}

\subsubsection{Aspectos históricos do direito autoral}

As constantes mudanças por que passam as sociedades levam a inovações em todos os setores das relações sociais, como é o caso do direito autoral. Considerando que este constitui o tema do presente estudo, faz-se necessário uma apresentação da evolução dos regimes de proteção ao direito de autor ao longo do tempo. Apesar de o estudo estar afeto à legislação brasileira, o desenvolvimento dos direitos autorais no mundo também constitui aspecto de grande importância para melhor entendimento dos fatores que levarão às conclusões dos problemas aqui propostos. Discutem-se primeiramente os aspectos mundiais e, posteriormente, enfocar-se-á a questão brasileira.

A literatura indica que o direito autoral surge na Idade Média, com o objetivo de tutelar (proteger) a empresa (editora) na medida em que é dado privilégio ou monopólio ao editor (impressor) da obra e não ao autor. Significa dizer que a intenção não foi proteger o autor, mas sim, desde o início, proteger os investimentos financeiros (ASCENSÃO, 1994, p.4). Mesmo sem uma forma oficial de controle da reprodução das obras, de meios de coibir ou punir quem o fizesse sem autorização do autor e de valorizar ou recompensar a produção intelectual, tal período se destaca por dois aspectos no que toca o início da proteção aos direitos autorais.

Em primeiro lugar, a criação e a difusão do alfabeto grego representou um grande salto para a evolução da escrita, conforme mencionado por Santos (2009, p. 21), o que se mostrou de fundamental importância à época de criação da imprensa. Em segundo lugar, destaca-se a questão moral sobre a autoria de uma produção 
intelectual. De fato, não havia na Antiguidade Clássica um sistema formal e oficial que regulamentasse a reprodução das obras, fato destacado por Araújo (1999, p. 10). Segundo o autor, mesmo sendo a Grécia o berço das artes e Roma a criadora do Direito (o assim chamado sistema romanístico), nada se sabia sobre como proteger a criação intelectual da utilização indevida, do plágio e da falsificação de obras.

Contudo, caso alguém se declarasse autor de uma obra que não fosse de fato sua, seria punido pela opinião pública, sendo o castigo a fama de plagiarius, comparados popularmente como ladrões comuns. Nesse sentido, Bittar (2001, p.12) observa que embora alguns autores vislumbrem a existência de um direito moral entre os romanos, em razão da action in jurarum (defesa dos interesses da personalidade), o direito de autor, tal como se discute hoje, não era conhecido na Antiguidade.

No século XV, o alemão Johannes Gutenberg (1398-1468) inventou uma máquina para impressão tipográfica, que permitiu a reprodução de obras literárias numa dimensão inimaginável àquela época. Até então, a reprodução dos textos ficavam a carga dos ditos copistas, que faziam um trabalho quase que artesanal para reproduzir uma obra. Assim, os autores não precisavam se preocupar com uma reprodução não autorizada em larga escala de suas produções, visto que era inviável. Entretanto, com a invenção de Gutenberg, intensificaram-se as discussões acerca dessa questão, em virtude da real possibilidade de perda do controle, por parte dos autores, sobre a reprodução das suas obras, devido à facilidade de multiplicação das cópias impressas.

Manso (1992, p.13) afirma, ainda, que

As leis nascem das necessidades sociais. Enquanto as obras intelectuais não se prestavam a uma exploração econômica de natureza verdadeiramente comercial, porque sua produção não podia realizar-se em escala industrial, nenhuma razão parecia haver para legislar-se sobre as violações que deveria ser direito dos autores. [...] Somente após o advento da imprensa, com os melhoramentos que Gutenberg introduziu com os tipos móveis, no século $X V$, é que surgiu a concreta necessidade de legislar sobre a publicação das obras, principalmente literárias. 
No entanto, as primeiras manifestações dessa evolução técnica dirigiam-se principalmente aos editores, com o estabelecimento de um regime de privilégios concedidos pelos monarcas para a exploração econômica das obras intelectuais. Segundo Cabral (2003, p.5) "o autor, no caso, não tinha qualquer vantagem econômica". O sistema em questão beneficiava impressores e vendedores de livros conhecidos como stationers. Ainda de acordo com o autor, um movimento de opinião favorável à liberdade de imprensa e aos direitos dos autores e contrária à Stationer Company de Londres começou a tomar forma em fins do século XVII. À época, autores se consideravam protegidos pela Common Law $^{2}$.

Além de contar com grande interesse econômico por parte dos monarcas, esse regime também era justificado pelo interesse em evitar que informações e, principalmente, opiniões de interesses contrários aos seus fossem amplamente divulgados. Era uma forma de instituir a censura, pois os editores, que eram indicados pelos próprios monarcas, tinham a liberdade para alterar os termos das obras que estavam autorizados a publicar. Assim, pode-se dizer que o poder central ganhava duas vezes. Primeiro, com o lucro financeiro. Segundo, com o controle das informações que eram publicadas e distribuídas.

Contudo, durante a Revolução Francesa, a propagação de novas ideias fez com que os autores se conscientizassem da importância da sua produção artística (ARAÚJO, 1999). Foi promulgada, então, na Inglaterra, a lei conhecida como o "Estatuto da Rainha Ana", invertendo os papéis. De acordo com Araújo (2004, p.5) "... agora os stationnaires - impressores e livreiros - poderiam continuar imprimindo suas obras, mas deveriam adquiri-las dos autores através de um contrato especial."

Já na França, surgiu o conceito de droit d'auteur, em que era reconhecido o direito à propriedade intelectual do criador sobre sua obra, sob o signo dos ideais de

${ }^{2}$ Common Law é a estrutura jurídica utilizada por países de origem anglo-saxônica como Estados Unidos e Inglaterra. Nesse ordenamento, o Direito se baseia mais na Jurisprudência do que no texto da lei.

Jurisprudência trata-se do conjunto de interpretações das normas do direito proferidas pelo Poder Judiciário. Disponível em: <http://direitoelegal.com/2008/02/28/common-law-e-civillaw/> Acesso em: 17 de out. 2015. 
liberdade, igualdade e fraternidade. A Revolução Francesa, como um movimento liderado pela classe burguesa contra a centralização da classe aristocrática, tinha como um de seus principais ideais o direito à propriedade, incluindo assim o direito de autor.

Como consequência das mudanças e atualizações sobre o tema, diversas reuniões entre países tomaram uma série de ações e medidas próprias para lidar com a questão. Além disso, o tema tornou-se de suma importância, provocando a realização de convenções específicas para sua discussão e tomada de decisão a respeito. É o que trata a seção seguinte.

\subsubsection{Acordos e tratados internacionais}

Após o surgimento do Estatuto da Rainha Ana na Inglaterra, muitos países editaram leis de proteção aos direitos de autor. Entretanto, as nações se recusavam a reconhecer os direitos de autor referentes a trabalhos de autores estrangeiros. Para tratar dessa e de outras questões pertinentes ao tema, foram realizadas sucessivas convenções sobre direitos autorais, que estabeleceram 0 reconhecimento do Direito de Autor entre nações soberanas. Dentre os acordos internacionais mais importantes na área de direito de autor estão a Convenção de Berna, que deu origem a duas outras convenções: de Genebra e de Roma; o Acordo sobre os Direitos de Propriedade Intelectual Relacionados ao Comércio (TRIPs) e o Tratado OMPI sobre Direito Autoral. Esses acordos serão explorados em seções específicas a seguir.

\section{Convenção de Berna}

A Convenção de Berna representa um modelo para as legislações sobre o tema direito autoral em diversos países do mundo, inclusive no Brasil. De acordo com informações constantes no site da UNESCO ${ }^{3}$, a Convenção se deu em 1886, foi revista em Paris (1896) e Berlim (1908), completada em Berna (1914), revista

3 Disponível em:<www.unesco.org/culture/ntlaws/media/pdf/bresil /brazil conv berna 09091886 orof.pdf>. Acesso em: 27 jul. 2015. 
novamente em Roma (1928), Bruxelas (1948), Estocolmo (1967) e Paris (1971), e, finalmente, emendada em 1979. Desde 1967 é administrada pela Organização Mundial de Propriedade Intelectual (OMPI/WIPO), incorporada ao sistema das Nações Unidas em 1974. Segundo a OMPI, a Assembleia da Convenção de Berna tem 165 países signatários, sendo o Brasil um deles. Para Cabral (2003, p.6), assim como para inúmeros outros autores, a Convenção de Berna constitui o mais antigo tratado internacional em vigor, e ainda aplicado. Apesar de ter sofrido várias revisões, o cerne de seu conteúdo - a defesa e proteção dos direitos patrimoniais e morais do autor - não foi alterado. Como observa EBOLI (2007, p.24), versa, assim, sobre três princípios fundamentais (figura 3) e norteadores de conduta homogênea no que diz respeito à proteção mínima dos direitos autorais nos países signatários.

O primeiro princípio garante que as obras originais de um Estado membro tem o direito de proteção idêntico nos demais estados membros, ainda que a legislação do outro estado seja mais benéfica. O segundo princípio, da proteção automática, assegura a proteção dos direitos autorais, independentemente de qualquer registro. Finalmente, o terceiro princípio parece óbvio, mas é esclarecido pela Convenção ao afirmar que independe da existência da obra no país para que ela detenha o direito de proteção dos direitos autorais.

Figura 3 - Princípios fundamentais da Convenção de Berna

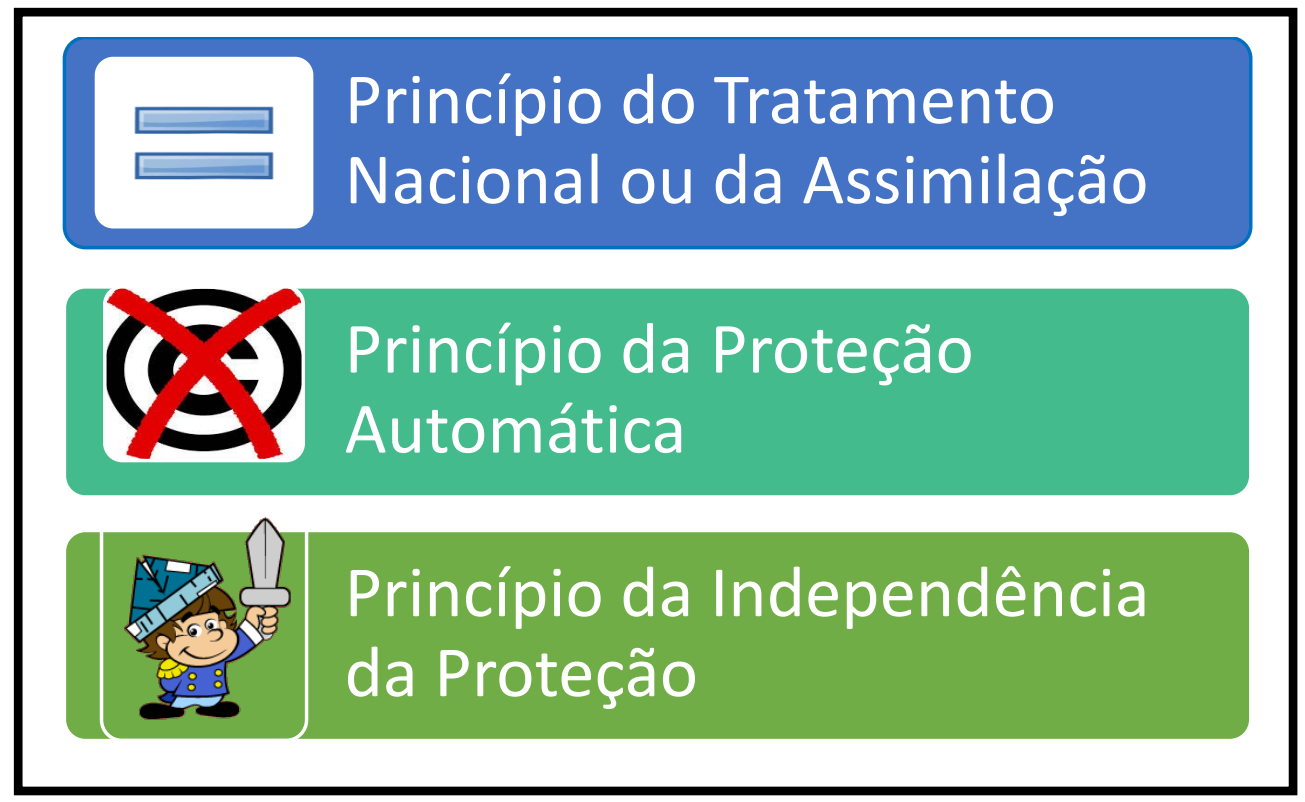

Fonte: a autora (2015). 


\section{Convenção Universal sobre o direito de autor (Convenção de Genebra)}

A criação da Convenção de Genebra surgiu pelo fato dos Estados Unidos divergir da proteção autoral instituída pela Convenção de Berna, principalmente com relação ao princípio da proteção mínima indispensável, adotado pelo copyright ${ }^{4}$. Esse princípio considera protegida qualquer obra desde que a primeira publicação consentida traga impresso o símbolo "()", que equivale à expressão "copyright", acompanhado do nome do titular do direito de autor, seguido da indicação do ano da primeira publicação (MENEZES, 2007, p. 33)

Considerando que as convenções de Genebra e de Berna apresentam características similares, parece interessante compará-las, mesmo que sucintamente. A Convenção de Genebra foi criada em 1952, com última revisão publicada em 1971, data da última alteração da Convenção de Berna. As duas são administradas pela Organização das Nações Unidas (ONU), porém (aqui reside uma das diferenças) a de Genebra não fica sob a responsabilidade da OMPI, mas sim da UNESCO. A Convenção de Genebra é visivelmente mais branda quando comparada com a Convenção de Berna e inclusive é tida como "Tratado multilateral que sugere e incentiva outros Estados a aderirem a Convenção de Berna" (ASCENSÃO, 1997, p. 641). Esse fato reside na tentativa de tornar o processo de garantia de proteção autoral mais ágil.

Autores de todo o mundo consideravam necessário conquistar a proteção dos seus direitos também no território americano. Isso porque os Estados Unidos, não sendo ainda signatário da Convenção de Berna, não reconhecia proteção internacional dos autores que os países signatários conseguiram alcançar. Esta foi, portanto, a grande motivação para a Convenção de Genebra, em relação à Convenção de Berna. Segundo Abrão (2002): "seu grande diferencial é o princípio da formalidade mínima indispensável", o que significa que a proteção de qualquer obra só está garantida a partir do momento em que a primeira publicação tenha o símbolo do copyright seguido do nome do autor, e indicação de data. ASCENSÃO

\footnotetext{
${ }^{4}$ Ver seção 2.3 .3
} 
(1997, p. 641) aponta quatro elementos fundamentais que justificam a criação da Convenção de Genebra:

- a pretensão de representar uma convenção verdadeiramente universal, por oposição a uma Convenção de Berna ainda então demasiadamente européia;

- a intenção de superar os obstáculos derivados da existência de sistemas tecnicamente diferentes, sobretudo os europeus e os americanos, mediante o estabelecimento de uma base mínima de proteção;

- a consagração de uma fórmula para os Estados Unidos se colocarem no centro do movimento protecionista do direito de autor sem aceitarem as exigências da Convenção de Berna;

- o aproveitamento da UNESCO como entidade administradora, dada a oposição existente entre a UNESCO e a OMPI, que ao tempo não era ainda agência especializada das Nações Unidas.

Em suma, o direito autoral internacional conta com duas principais convenções que o regulam. A primeira, de Berna, garante proteção à obra desde o momento em que é concebida, independentemente de ter sido publicada ou não, observando a proteção do caráter moral da obra. A segunda de Genebra, garante proteção sob duas condições: a obra estar tanto publicada quanto registrada com o símbolo que a caracteriza, seguida do autor e data. (ABRÃ̃O, 2002).

\section{Convenção de Roma}

Seguindo os objetivos das Convenções de Berna e Genebra, a Convenção de Roma continua assegurando a proteção do direito de autor sobre suas produções artísticas ou literárias (AFONSO, 2009, p. 143). No entanto, assegura, ainda, a proteção dos intérpretes (ou executantes), dos produtores e dos organismos de radiodifusão. As primeiras propostas para a proteção dos intérpretes surgiram na ocasião da conferência para revisão da Convenção de Berna, em Roma, no ano de 1928. Contudo, a Convenção de Roma foi assinada somente em 1961, e passou a ser considerada como norteadora da proteção internacional dos direitos conexos. (FRAGOSO, 2009, p.99).

Ao contrário da Convenção de Berna, a Convenção de Roma não é administrada somente pelo OMPI, mas também pela UNESCO e pela OIT, tendo atualmente 88 países signatários, sendo o Brasil também um deles (ZANINI, 2011, 
p.123). Acrescente-se, ainda, que os Estados Unidos julgaram que a Convenção de Roma havia sido fundada em princípios do direito continental (Direito europeu) e não a validaram, pois o país segue manifestadamente a Common Law.

\section{Acordo TRIPS}

Outra negociação internacional importante que versa sobre as questões de direitos autorais é o Acordo sobre Aspectos dos Direitos de Propriedade Intelectual Relacionados ao Comércio (TRIPS) que surgiu no fim da Rodada do Uruguai ${ }^{5}$. Assim ficou conhecido, conforme Lampreia (1995, p. 247), o encontro internacional que transformou o Acordo Geral de Tarifas e Trocas (GATT) na Organização Mundial do Comércio (OMC). Diferentemente dos demais acordos internacionais de propriedade intelectual o TRIPS tem um poderoso poder de execução, já que para o país ser membro da OMC deve compulsoriamente ratificar o acordo. Conforme afirma Lampreia (1995, p. 248), o acordo dispõe sobre cinco questões. A primeira, sobre a aplicabilidade dos princípios do GATT e de acordos internacionais sobre propriedade intelectual. A segunda, sobre a estipulação dos diretos de propriedade intelectual adequados. A terceira, sobre a determinação de medidas eficazes ao cumprimento dos direitos de propriedade. A quarta, sobre a previsão de mecanismos para solução multilateral de controvérsias. Finalmente, trata sobre disposições transitórias, em especial aquelas relacionadas à data de sua implementação.

O TRIPS se distingue da Convenção de Berna por regular o Direito de Propriedade Intelectual relacionado à Propriedade Industrial (direito de patentes) e não necessariamente aos Direitos Autorais da Propriedade Intelectual ${ }^{6}$. Embora o

\footnotetext{
${ }^{5}$ A Rodada do Uruguai ocorreu em 1995 e consistiu de reunião internacional que deu origem à Organização Mundial do Comércio, sob a chancela da ONU.

${ }^{6}$ A Convenção da OMPI define como Propriedade Intelectual "a soma dos direitos relativos às obras literárias, artísticas e científicas, às interpretações dos artistas intérpretes e às execuções dos artistas executantes, aos fonogramas e às emissões de radiodifusão, às invenções em todos os domínios da atividade humana, às descobertas científicas, aos desenhos e modelos industriais, às marcas industriais, comerciais e de serviço, bem como às firmas comerciais e denominações comerciais, à proteção contra a concorrência desleal e todos os outros direitos inerentes à atividade intelectual nos domínios industrial, científico, literário e artístico." O ordenamento jurídico brasileiro divide a Propriedade Intelectual em
} 
TRIPS estabeleça requisitos mínimos para patentes, a especificidade do que deve ou não ser patenteado fica a critério do regulamento de cada país. Além disso, o TRIPS orienta que para uma produção intelectual ser patenteada, deve atender aos requisitos de novidade, atividade inventiva e aplicação industrial. Trata-se, na verdade, de um dos acordos multilaterais mais importantes da área de Propriedade Intelectual do mundo relacionado principalmente à propriedade intelectual industrial.

\section{Tratado OMPI (WIPO) sobre direito autoral}

Após a $2^{\mathrm{a}}$ Guerra Mundial, o direito internacional sofreu mudanças que afetaram diretamente os direitos de propriedade intelectual. Os sistemas da Convenção de Berna e da Convenção de Genebra já não eram mais tão eficazes, necessitando de uma reforma estrutural, que foi consolidada durante a Convenção de Estocolmo em 1967, dando origem à Organização Mundial da Propriedade Intelectual (OMPI).

A OMPI foi criada em 1967, transformando-se, em 1974, em um Comitê Especializado da ONU. Tornou-se, assim, o órgão centralizador e administrador de várias convenções internacionais e "conta atualmente com o gerenciamento de 24 tratados, incluindo a Convenção de Paris e a Convenção de Berna" (ZANINI, 2011, p.124). Tem 180 integrantes, incluindo o Brasil. O Tratado OMPI foi assinado em 1996, em Genebra. Um de seus principais objetivos é reagir aos desafios advindos da era das tecnologias digitais, como a internet. Basso (2000, p. 159-160) define os objetivos do Tratado como

o fomento e a cooperação entre todos os estados unionistas ou qualquer organização internacional, bem como a adoção de medidas destinadas ao aprimoramento da proteção à propriedade intelectual e harmonização das leis nacionais sobre a matéria.

O Tratado reflete na maneira como o direito autoral e os direitos conexos devem ser aplicados no contexto atual, inclusive à luz das tecnologias digitais. Ademais, os países signatários acordaram que cada país seria o próprio 
responsável por proteger, representar e assegurar os direitos de seus autores. Nesse sentido, há o reconhecimento da necessidade de "manter equilíbrio entre o direito autor e o interesse público, especialmente no domínio da educação, da investigação e do acesso à informação, conforme refletido na Convenção de Berna". (TRATADO OMPI, 1996).

É importante destacar que os direitos já existentes, debatidos em outras convenções, ficam, assim, resguardados também em meio digital. Mais que isso, garantem a seus detentores que seus direitos continuarão sendo aplicados e defendidos quando suas obras forem distribuídas por meio de novos sistemas de comunicação inseridos por empresas como Google, Apple, Netflix, dentre outras.

\subsubsection{Direito de autor (Droit d'auteur) versus Copyright}

Conforme mencionado anteriormente, a proteção do autor surgiu formalmente com o Estatuto da Rainha Ana, na Grã-Betanha, em 1710. Essa lei concedeu, na realidade, um privilégio de reprodução: "shall have the sole right and liberty of printing such books", dando assim, origem à visão anglo-saxônica do copyright (direito de cópia). O copyright era um direito de impressão reconhecido como sistema comercial. Tridente (2009, p.28) acrescenta que, originalmente, o copyright consistia na exclusividade para reprodução de um texto. Ou seja: consistia no direito de fazer cópias.

Já o continente europeu caminhou em outra direção - do droit d'auteur -, priorizando a proteção jurídica do direito autoral na atividade criadora em si ao invés de tutelar a materialidade do exemplar, como no copyright. Ascensão (1997, p. 5) assegura que "o caminho seguido foi o da afirmação de uma propriedade do autor sobre a obra, aproveitando a sacralização que aquele direito se outorga. $O$ direito de autor seria até a mais sagrada de todas as propriedades". Mesmo assim, o conflito entre a proteção da obra e proteção de sua materialidade subsiste até os dias atuais, quer em instrumentos internacionais quer em leis nacionais. Isso porque continuam a se referir a livros, folhetos e outros escritos, sem perceber que o que é protegido é a obra literária e não as modalidades variáveis da sua materialização. 
O Droit d'auteur baseia-se na teoria unionista e reconhece a parte do direito moral e patrimonial dos direitos autorais. Para tanto, reconhece "a relação criativa entre o autor e sua obra e o seu direito de utilizá-la economicamente (SOUZA, 2003, p.38). De acordo com Gandelman (2001, p. 32), o droit d'auteur enfoca "os aspectos morais, o direito que o autor tem ao ineditismo, à paternidade, à integridade de sua obra, que não pode ser modificada sem o seu expresso consentimento". Assim, ainda que o autor ceda (transfira) todos os seus direitos patrimoniais, ele permanece com os direitos morais, os quais, por sua vez, são inalienáveis e irrenunciáveis. A proteção se estende por toda a vida do autor, a até mesmo após a sua morte, transferindo-se todos os direitos patrimoniais e morais para seus herdeiros e sucessores legais como será visto em seção específica que tratará da transferência dos direitos autorais.

Durante muito tempo, a distinção entre o entendimento sobre direito de autor e o copyright era tão evidente que até o final do século XX os Estados Unidos resistiram em conferir direitos morais aos autores. Por isso, somente em 1989 é que os norte-americanos aderiram à Convenção de Berna, o que não se deu sem discussão e desentendimentos.

O sistema comercial defende que o objeto de proteção do copyright seria a sociedade americana como um todo, procurando garantir a essa sociedade o benefício dos resultados das produções intelectuais (científicas e artísticas), em detrimento de garantir uma recompensa aos autores. Diferencia-se, assim, do direito autoral (Droit d'auteur), visto que o primeiro seria a regulamentação do direito de produzir cópias, enquanto o segundo seria a proteção dos direitos de propriedade do autor sobre sua produção criativa. (JOYCE et al, 2003, p. 03)

No regime de copyright, os procedimentos formais para se conseguir o registro da obra exigiam o cumprimento de diversas formalidades, divididos em três passos básicos, que incluíam o registro do trabalho em um escritório governamental, uma declaração de propriedade e o depósito da obra em repartição pública. Todas as exigências deveriam ser adotadas pelo requerente da proteção e, caso todos os passos não fossem devidamente observados, a obra se tornaria de domínio público 
(REESE, 2007, p. 136-138). Em contrapartida, o droit d'auteur garante que a proteção do direito do autor se adquire automaticamente, sem registro, nem outras formalidades. Conforme a informação apresentada pela OMPI, o sistema droit d'auteur busca um equilíbrio justo entre os interesses dos autores e do público, que por sua vez, defende o acesso amplo às publicações.

O regime copyright, além de ser tutelado durante toda a vida do autor assim como os demais regimes, protege o direito de autor por noventa e cinco anos após a sua morte. Esse período foi retificado de 70 para 95 após a entrada em vigor da Lei Sony Bono, em 1992, e da Lei do Mickey Mouse, em 1998. Essas prorrogações no prazo de proteção do Copyright evidenciam o interesse dos Estados Unidos na proteção do lucro pela exploração exclusiva de obras artísticas e científicas. (LESSIG, 2004, p. 118). No droit d'auteur ainda prevalece a duração de 70 anos após a morte do último co-autor.

Sobre os princípios jurídicos que regem os dois sistemas, é cabível citar que o o copyright adota o common Law (ou direito inglês) que, segundo Oliveira (2014, p. 47) tem como fonte do direito, os costumes, firmados pelos precedentes dos tribunais (jurisprudências). Em contrapartida, o droit d'auteur é regido pelo civil law (ou direito romano), onde a principal fonte do direito eram os costumes da sociedade, ou aquilo que os membros dela consideravam correto.

Neste cenário, é importante ressaltar que o Brasil adota a corrente unionista (droit d'auteur) já que admite a peculiaridade do direito autoral diante da característica moral e patrimonial que ele possui. Nesse sentido, a distinção entre os dois sistemas mostrou-se fundamental para o presente estudo, visto que são abordados países dos continentes europeu, norte-americano e sul-americano. De fato, a confusão entre os termos tem gerado um desconforto jurídico, o que torna essa distinção necessária e relevante.

\subsubsection{Direito autoral no Brasil}

Segundo Manso (1989, p.16), o primeiro registro de algum tipo de regulamentação sobre direito de autor foi a promulgação da lei que instituiu os 
cursos de Direito nas faculdades de São Paulo e Olinda em 1827. Nesta, os professores nomeados deveriam encaminhar compêndios das matérias que pretendiam lecionar e, caso fossem aprovados, teriam proteção das obras enviadas por um prazo de 10 (dez) anos. Contudo, tal regulamentação atingia apenas os professores das Faculdades de Direito de São Paulo e Olinda, sendo, portanto, inócua aos demais autores.

Já em 1830, por meio do Código Criminal em seu artigo 261, foi reconhecido que a reprodução de obras intelectuais sem a autorização expressa do respectivo autor é crime sujeito a pena. Entretanto, apesar do avanço, nada se falava sobre proteção do direito de autores estrangeiros.

O Código Penal de 1890 manteve a linha de se legislar sobre direitos autorais, dessa vez com inspiração nas legislações de Portugal e da França. No ano seguinte, o tema tornou-se questão constitucional, ao ser incluído na Constituição Brasileira daquele ano. Desde então (salvo na Constituição de 1937, sob o signo da ditadura do Estado Novo de Getúlio Vargas) todas as Constituições brasileiras previam expressamente a tutela dos direitos autorais:

(CF 1891) Art. 72 - A Constituição assegura a brasileiros e a estrangeiros residentes no País a inviolabilidade dos direitos concernentes à liberdade, à segurança individual e à propriedade, nos termos seguintes:

$\$ 26$ - Aos autores de obras literárias e artísticas é garantido o direito exclusivo de reproduzi-las, pela imprensa ou por qualquer outro processo mecânico. Os herdeiros dos autores gozarão desse direito pelo tempo que a lei determinar.

$\mathrm{Na}$ atual Constituição Federal (CF de 1988), o tema está positivado como direito fundamental, nos incisos XXVII e XXVIII de seu artigo $5^{\circ}$

Art. $5^{\circ}$ - Todos são iguais perante a lei, sem distinção de qualquer natureza, garantindo-se aos brasileiros e aos estrangeiros residentes no País a inviolabilidade do direito à vida, à liberdade, à igualdade, à segurança e à propriedade, nos termos seguintes:

XXVII - Aos autores pertence o direito exclusivo de utilização, publicação ou reprodução de suas obras, transmissível aos herdeiros pelo tempo que a lei fixar.

XXVIII - São assegurados, nos termo da lei: 
a) a proteção às participações individuais em obras coletivas e à reprodução da imagem e voz humanas, inclusive nas atividades desportivas;

b) o direito de fiscalização do aproveitamento econômico das obras que criarem ou de que participarem aos criadores, aos intérpretes e às respectivas representações sindicais e associativas.

A Constituição de 1988, conhecida como "Constituição Cidadã", trouxe inovações no sentido de abranger uma grande gama de possibilidades de obras a serem protegidas pelo direito autoral. Para tanto, utilizou-se de expressões genéricas e observou a tendência internacional de considerar como passível de tutela as bases de dados eletrônicas, software e programas de computador. $\mathrm{Na}$ verdade, a preocupação do legislador constituinte foi além e vislumbra a proteção não apenas da obra do autor, mas também de sua imagem e/ou voz, conforme o caso. Também é garantida a proteção dos direitos individuais de cada participante da criação de uma obra coletiva. Ao colocar a tutela dos direitos autorais na seção de Direitos e Garantias Fundamentais da Constituição Federal, o legislador conferiu uma proteção especial ao direito autoral no âmbito do ordenamento jurídico pátrio. Isso porque elevou seu status como de algo fundamental para a garantia do Estado Democrático de Direito ante a sociedade brasileira.

No âmbito infraconstitucional, o tema passou a ser especificamente regulado através da lei $n^{\circ} 496$, de $1^{\circ}$ de agosto de 1898. Apesar de pioneira, essa lei pode ser considerada retrógrada, especialmente porque exigia um registro da obra como requisito para sua proteção (GANDELMAN, 2001, p.32). Tal regulamento ainda não previa a proteção de obras de intelectuais estrangeiros e, à época, era corrente a ideia de que obras estrangeiras podiam ser livremente reproduzidas.

O ordenamento jurídico brasileiro só previu a proteção de direitos de autor sobre obras de autores após a publicação da lei n 2.577, de 17 de janeiro de 1912 . Essa lei veio ampliar o escopo de proteção da lei anterior (lei n 496/1898):

Art. $1^{\circ}$ - Todas as disposições da Lei n. 496, de 1 de agosto de 1898, salvo as de seu art. 13, são igualmente applicaveis ás obras scientíficas, litterarias e artisticas, editadas em paizes estrangeiros, qualquer que seja a nacionalidade de seus autores, desde que elles pertençam a nações que tenham adherido ás convenções internacionaes sobre a materia, ou tenham assignado tratados com o 
Brazil, assegurando a reciprocidade do tratamento ás obras brazileiras.

Observe-se a importância da Convenção de Berna no trato da questão de direitos de autor no âmbito brasileiro. Para que fosse reconhecida a propriedade de obra estrangeira era fundamental a caracterização da reciprocidade sobre a questão com o país de origem do autor, seja por acordos multilaterais, seja por acordos bilaterais. No entanto, em 1916, com a publicação do Código Civil, as leis anteriores foram revogadas e o direito autoral passou a ser tutelado por aquele diploma legal. Embora o tratamento dado à matéria tenha sido elogiável, o direito autoral perdeu sua autonomia legislativa, haja vista que passou a ser considerado como uma simples propriedade. Conforme ensina Manso (1992, p.13), "a perda da autonomia legislativa atrasou o desenvolvimento científico do direito autoral no Brasil". Contudo, com a promulgação da lei no 5.988 em 1973, os artigos 649 a 673 daquele Código Civil (que tratavam sobre direitos autorais) foram revogados e o tema voltou a ter sua autonomia legislativa. A nova lei estava em conformidade com a Convenção de Berna, como também agregava textos e preceitos de legislações anteriores.

A Convenção de Berna foi finalmente ratificada no Brasil - bem como todas as suas alterações até então - pelo Decreto n 75.699, de 06 de maio de 1975. A partir desse momento o ordenamento jurídico brasileiro estava alinhado com as diretrizes internacionais que regulam a questão em comento.

Atualmente, está em vigor no Brasil a Lei de Direitos Autorais - LDA (Lei no 9.610, de 19 de fevereiro de 1998) que, segundo Santos (2009, p.54) "[...] apresenta uma série de dispositivos que convergem para a manutenção do poder do autor ou de seus representantes em proibir ou decidir quem utilizará e como serão exploradas economicamente suas criações". Comparada com os demais regulamentos sobre direito autorais no mundo, a LDA pode ser considerada desfavorável no que se refere ao acesso às informações. Isso porque é uma das legislações mais restritivas para o consumidor da informação. De acordo com o artista e ex-Ministro de Estado da Cultura, Sr. Gilberto Gil (2010), esse fato não condiz com a realidade socioeconômica do país 
É importante que através das leis, dos processos de regulação, se mantenha o equilíbrio, o mais justo possível, entre o direito dos autores, dos criadores, enfim, artistas, criadores intelectuais de um modo geral, e do outro lado o interesse público.

A Consumers Internacional, federação que congrega entidades de defesa do consumidor de todo o mundo, considerou que a legislação de direito autoral brasileira constitui um dos piores regimes de direito autoral. Assim, enquanto a tecnologia propicia novas formas de inclusão social, ao ampliar o acesso ao conhecimento, e de produção cultural, a partir da criação e da troca de bens intelectuais, a legislação autoral brasileira desconsidera esses fatores. Mais que isso, "as regras atuais têm colocado na ilegalidade atos tão corriqueiros como copiar uma música de um CD legalmente adquirido para um computador ou para um aparelho portátil" (LEMOS et al, 2011, p. 47).

Estudo realizado pelo Instituto Brasileiro de Pesquisa e Defesa do Consumidor (IDEC) em 2010 abordou cinco questões (LEMOS et al, 2011, p.47). A primeira, as possibilidades trazidas pela legislação autoral para o acesso dos consumidores a serviços e produtos culturais. A segunda, exceções e limitações para usos educacionais das obras. A terceira, a preservação do patrimônio cultural. A quarta, a acessibilidade. Finalmente, a adaptação da lei aos novos modelos digitais e utilização privada dos bens culturais. Os resultados apontaram a legislação brasileira como o quarto pior ordenamento jurídico do mundo no quesito direito autoral. A partir desse resultado, Lemos et al (2011, p.47) concluíram que "estamos ficando para trás no processo de democratização dos direitos autorais, com uma lei ultrapassada, incapaz de lidar com a sociedade digital em que vivemos."

Considerando a universalidade do tema do presente estudo, é importante apontar como o direito autoral vem sendo tratado em outras regiões do mundo. Destacam-se, tanto por sua importância internacional quanto pela abrangência do estudo, o direito autoral nos Estados Unidos e na Europa.

\subsubsection{Direito autoral nos Estados Unidos}

Os Estados Unidos sempre consideraram primeiro os direitos nacionais de seus autores ao invés de priorizarem tratados internacionais, optando por não 
proteger a produção estrangeira, embora dando livre acesso à produção inglesa em seu território. (Barbosa, 2010, p.2). É fato conhecido e ratificado pelo histórico da legislação anglo-saxônica que os Estados Unidos sempre favoreceram o sistema comercial, ou copyright, objetivando a proteção da obra em si, diferentemente da Europa, onde são considerados prioritariamente os direitos morais do autor. Os Estados Unidos excluíram propositadamente os direitos morais, até a ocasião da segunda revisão da Convenção de Berna, quando o país decidiu subscrevê-la, dando origem à Convenção de Roma e passando a ser país signatário de ambas em 1989.

Com o passar do tempo, os Estados Unidos começaram a se preocupar com o surgimento efetivo das mais variadas formas de circulação das obras, o que favorecia a pirataria e violava a lei de copyright. Por conseguinte, o país buscou, segundo Araya (2009, p. 45), novas possibilidades legais para combater a facilidade de se copiar conteúdo sob proteção do copyright e limitar sua divulgação. Adotaram, segundo a autora, o Digital Millenium Copyright Act, que criminaliza a produção e a distribuição de tecnologias que facilitam infringir os direitos de autor. Nesse contexto, várias medidas passaram a ser tomadas com objetivo de adaptar a legislação em face dos desafios trazidos pela digitalização dos dados e pelo uso da Internet, uma vez que a proteção aos direitos autorais parecia ameaçada (ROHRMANN,2001, p.2). Arnold (1995, p. 6) acrescenta que, no meio eletrônico, o conceito de direito moral do autor mudou de modo "considerável, e talvez, útil" nas discussões sobre copyright, e essa questão "terá que ser considerada em qualquer revisão da lei de copyright".

Standler (2012, p.7) apresenta um breve panorama sobre os direitos morais do autor nos Estados Unidos, destacando quatro aspectos. O primeiro aborda o conceito de atribuição, segundo o qual um autor não tem direito legal de ter seu nome fixado em seu trabalho a menos que tal direito esteja incluído no contrato escrito entre ele e a editora. O segundo refere-se ao conceito de integridade, significando que o autor não tem direito legal para prevenir cortes ou distorção do seu trabalho. $O$ terceiro aspecto discute o conceito de divulgação, significando que o direito moral de divulgação é equivalente ao direito americano de primeira 
publicação. $\mathrm{Na}$ verdade, são conceitos diferentes, mas que produzem o mesmo resultado ${ }^{7}$. Finalmente, o conceito de revogação é apresentado, significando que não é legal o autor revogar seu trabalho após a publicação.

Considerando que toda forma de proteção dos direitos autorais provem do interesse mútuo de determinada categoria, o surgimento de associações que defendem os interesses coletivos de grupos abrangentes ou específicos cresce ao redor de todo o mundo (MENEZES, 2007, p. 144). Nos Estados Unidos, dois exemplos dessa tendência são a Copyright Society of the USA e a American Society of Composers, Authors and Publishers. A primeira, criada em 1953, é uma organização sem fins lucrativos com cerca de 1.000 membros, dedicada à consciência e educação da lei de copyright. Fomenta o interesse e avança no estudo e compreensão da lei de direitos autorais em literatura, música, arte, teatro, cinema, televisão, programas de computador, arquitetura, e outras obras de autoria, além de sua distribuição por meios de comunicação tradicionais e novos. (COPYRIGHT SOCIETY, USA). A segunda se preocupa especificamente com os direitos dos autores musicais do país e tem aproximadamente 550.000 associados. Conforme o site oficial da Associação, firma acordos com sociedades internacionais, representando, assim, centenas de milhares de criadores de música em todo o mundo.

Os Estados Unidos são considerados uma nação protecionista com relação ao direito autoral. Apesar de estar entre os países mais beneficiados - se consideradas as remessas internacionais de royalty por direito autoral -, seu regime ocupa o segundo lugar entre os países com legislações autorais mais amigáveis. Isso porque "até os EUA adotam exceções e limitações aos direitos autorais com um escopo maior e entendem a importância destas para o desenvolvimento nacional" (LEMOS et al, 2011, p.47).

Os autores supracitados concluem que o resultado de uma lei com limitações mais equilibradas aos direitos autorais propicia um ambiente de intensa

\footnotetext{
${ }^{7} \mathrm{O}$ direito à primeira publicação é defeso ao autor e não ao editor. (JOYCE et al, 2003, p.12)
} 
colaboração, inovação e difusão do conhecimento. Isso porque, conforme Lemos et al (2011, p. 48) "graus maiores de liberdade na utilização de obras autorais repercutem diretamente em resultados economicamente favoráveis ao país". As limitações ao direito de autor serão abordadas na seção 2.3.7.

\subsubsection{Direito autoral na Europa}

As primeiras tentativas de unificar o entendimento sobre os direitos autorais na Europa se deram ainda na ocasião da Convenção de Berna, sendo signatários todos os países do continente. Contudo, ainda há países na Europa que seguem a Common Law, regime anglo-saxão (Irlanda e Reino Unido, por exemplo). A maioria, no entanto, segue o Droit d'auteur.

Menezes (2007, p. 144) afirma que o entendimento sobre o sistema coletivo de administração autoral está consolidado na Europa. A autora aponta, entre as instituições que se desenvolveram, a Sociedade Geral de Autores da Espanha (SGAE), para gerir o direito autoral. A Sociedade faz parte de um modelo de administração única e tem como escopo proteger cada titular do direito autoral na sua modalidade de criação. O modelo de administração única foi seguido por outros países como Portugal, com a Sociedade Portuguesa de Autores (SPA), e Itália, com a Sociedade Italiana dos Autores e Editores (SIAE). (MENEZES, 2007, p. 145)

Em 2001, segundo a Directive 2001/29/EC of the European Parliament and of the Council, que dispõe sobre os direitos autorais na sociedade da informação ${ }^{8}$, a comunidade europeia discursou sobre aspectos específicos da proteção autoral. Resolveu, então, que deveriam criar um acordo a fim de harmonizar as legislações dos Estados-Membros com relação ao direito de autor e direitos conexos. Com isso, o Conselho Europeu se reuniu em Corfu em junho de 2004 e ressaltou a "necessidade de criar, a nível comunitário, um enquadramento legal geral e flexível que estimule o desenvolvimento da sociedade da informação na Europa".

\footnotetext{
${ }^{8}$ Disponível em: <http://eur-lex.europa.eu/LexUriServ/ LexUriServ.do? uri=OJ:L:2001: 167:0010:0019:EN:PDF>. Acesso em: 18 out. de 2015.
} 
No entanto, entre dezembro de 2013 e março de 2014 a Comissão Europeia lançou uma consulta pública para tratar da atualização das regras de direitos autorais na União Europeia, com prazo de votação no primeiro semestre de 2015. Entretanto, até a conclusão deste trabalho, não havia ainda um posicionamento concreto sobre a atualização da política no continente.

\subsubsection{Limitações ao direito autoral}

A doutrina do fair use (uso justo da obra) surgiu no direito norte-americano para ser um ponto de equilíbrio entre o direito autoral e o interesse da coletividade. Essa teoria distingue o uso justo, legítimo ou adequado do uso injusto ou inadequado, que configura violação ao direito autoral. Desse modo, uma pessoa pode utilizar livremente a obra protegida de terceiro com a finalidade de crítica, comentário, notícia, ensino (incluindo as cópias múltiplas destinadas ao uso em sala de aula), dentre outras utilizações, sem precisar nem mesmo da autorização do autor.

Nesse sentido, Leite (p. 10, 2004) ressalta que até mesmo em países que adotam a corrente das limitações específicas - e cuja interpretação, a priori, deve ser exaustiva -,como a França, alguns usos de obras intelectuais não elencados no rol das limitações são interpretados pelas cortes como sendo razoáveis e justos. Portanto, não constituem violações ao direito de autor. A corrente das limitações específicas, mencionada por Leite (2004), nasce tal como a dos direitos autorais, no século XVII.

Menezes (2007, p.96) explica que os limites do direito autoral se justificam por três razões. A primeira refere-se ao direito da sociedade à informação, em que o direito coletivo sobrepõe-se a qualquer interesse privado. A segunda, sobre necessidade de desenvolvimento da educação, estabelece que as regras autorais não podem impor limites que impeçam a atrapalhem o aprendizado e a divulgação da cultura. Por fim a terceira faz menção aos usos técnicos e judiciais, relacionado ao fato de que sempre que o direito do autor esbarrar no funcionamento do comércio e administração da justiça há necessidade de conciliação, de modo que nenhuma das partes saia prejudicada. 
Sobre essas questões, a Convenção de Berna estabelece o chamado "três passos" para regulamentar as limitações no plano internacional

Fica reservada às legislações dos países da União a faculdade de permitir a reprodução das referidas obras, (1) em certos casos especiais, (2) desde que tal reprodução não prejudique a exploração normal da obra (3) nem cause um prejuízo injustificado aos legítimos interesses do autor.

No contexto brasileiro, o artigo 46 da lei de direitos autorais não considera uma ofensa aos direitos autorais:

I - a reprodução: a) na imprensa diária ou periódica, de notícia ou de artigo informativo, publicado em diários ou periódicos, com a menção do nome do autor, se assinados, e da publicação de onde foram transcritos; b) em diários ou periódicos, de discursos pronunciados em reuniões públicas de qualquer natureza; c) de retratos, ou de outra forma de representação da imagem, feitos sob encomenda, quando realizada pelo proprietário do objeto encomendado, não havendo a oposição da pessoa neles representada ou de seus herdeiros; Departamento de Direito d) de obras literárias, artísticas ou científicas, para uso exclusivo de deficientes visuais, sempre que a reprodução, sem fins comerciais, seja feita mediante o sistema Braille ou outro procedimento em qualquer suporte para esses destinatários;

II - a reprodução, em um só exemplar de pequenos trechos, para uso privado do copista, desde que feita por este, sem intuito de lucro;

III - a citação em livros, jornais, revistas ou qualquer outro meio de comunicação, de passagens de qualquer obra, para fins de estudo, crítica ou polêmica, na medida justificada para o fim a atingir, indicando-se o nome do autor e a origem da obra;

IV - o apanhado de lições em estabelecimentos de ensino por aqueles a quem elas se dirigem, vedada sua publicação, integral ou parcial, sem autorização prévia e expressa de quem as ministrou;

Avancini (2009, p.63) afirma que tanto o direito à informação quanto os direitos autorais não são direitos absolutos, comportando limites no exercício dos direitos e autor, seja por fatores relacionados à cultura, à educação ou à personalidade. Cabral (1998, p.4) complementa essa afirmação, afirmando que manter o equilíbrio entre duas situações aparentemente antagônicas é uma construção jurídica invejável: de um lado um direito natural, com propriedade específica e de outro o direito de acesso livre. 


\subsubsection{Transferência dos direitos autorais: direito moral e direito patrimonial}

A questão da transferência dos direitos autorais, tanto o direito moral quanto o direito patrimonial, refere-se exclusivamente ao caso brasileiro, visto que só foi possível estudá-los nesse contexto. Desse modo, é importante destacar que o direito autoral possui uma peculiaridade diante dos demais direitos, pois é visto sob duas óticas. A primeira é destinada ao direito moral, que compreende, dentre outros direitos, o ineditismo e a atribuição, ou seja, o direito do autor de ser citado (BRASIL, 1998). A segunda está relacionada ao direito de propriedade que é o direito patrimonial da obra. Cabe ao autor o direito de dispor dos direitos de autor da maneira que Ihe convém, já que é o titular original da propriedade intelectual.

A respeito dessa discussão, Silveira (1996, p.15) observa que independente do tipo de criação - idéias abstratas invenções ou obras artísticas -, o trabalho criativo é de um só tipo e é o fruto dessas atividades que é protegido. Nesse sentido, segundo o autor, a obra pertence a seu criador e "só a ele compete decidir revelá-la, pondo-a no mundo, e esse fato não destrói a ligação original entre a obra e o autor" (SILVEIRA, 1996, p. 14-15).

\section{Direito moral}

È relevante notar que o direito moral do autor é eterno e indissolúvel. Uma vez que a obra foi criada, o autor não pode abdicar da paternidade de sua obra. Cabral (2000, p.41-42) complementa que "ela pode ter qualquer destino, mas jamais será desvinculada de quem a criou". Para Bittar (1992), o direito moral destina-se a resguardar a proteção da personalidade do autor e, portanto, irrenunciável.

No Brasil, o art. 24 da Lei de Direitos Autorais (BRASIL, 1998) elenca, nos seus incisos I a VII, o direito moral defeso ao autor

Art. 24. São direitos morais do autor:

I- o de reivindicar, a qualquer tempo, a autoria da obra;

II- o de ter seu nome, pseudônimo ou sinal convencional indicado ou anunciado, como sendo o do autor, na utilização de sua obra;

III- o de conservar a obra inédita;

IV- o de assegurar a integridade da obra, opondo-se a quaisquer modificações ou à pratica de atos que, de qualquer forma, possam prejudicá-la ou atingi-lo, como autor, em sua reputação ou honra; 
V- o de modificar a obra, antes ou depois de utilizada;

VI- o de retirar de circulação a obra ou de suspender qualquer forma de utilização já autorizada, quando a circulação ou utilização implicarem afronta à sua reputação e imagem;

VII- o de ter acesso a exemplar único e raro da obra, quando se encontre legitimamente em poder de outrem, para o fim de, por meio de processo fotográfico ou assemelhado, ou audiovisual, preservar sua memória, de forma que cause o menor inconveniente possível a seu detentor, que, em todo caso, será indenizado de qualquer dano ou prejuízo que lhe seja causado.

Cabe destacar que os direitos aventados pelos incisos de I a IV podem ser transferidos aos sucessores do autor por ocasião de sua morte. O art. 27 da lei caracteriza o direito moral como direitos inalienáveis e, com isso, o autor não pode dispor de alguns de seus direitos. É possível, ainda, adicionar a imprescritibilidade às características, já que o direito moral não prescreve com o decurso do tempo. Portanto, a única transferência que o direito moral de autor permite é com relação aos efeitos dos incisos I a IV, do art. 24 da Lei 9.610/98 aos sucessores. Mas, ainda assim, o autor é o pai (criador) da obra e a ele devem ser atribuídos os direitos morais que se prolongam além da vida.

\section{Direito patrimonial}

No que concerne aos direitos patrimoniais, também denominados de materiais, diferentemente dos direitos morais, podem ser transferidos por meio de cessão, concessão ou licenças. Isso porque são tratados como direito de propriedade. Ainda assim, Cabral (2003, p. 48-49) observa que tal propriedade é peculiar, por "ser material, configurada em algo palpável, mas, ao mesmo tempo, incorpórea".

Dias (2000, p. 31) afirma que o direito de propriedade do direito autoral está relacionado com o direito de exclusividade, "ponto fulcral de todo o sistema de proteção autoral". Na avaliação do autor, "uma vez criada a obra, ela pertende ao seu criador, que tem direitos exclusivíssimo, inclusive de não divulgá-la ao público, se for assim eu desejo". Mais que isso, o criador pode, também, "retirar uma obra de circulação quando quiser". Sobre essas questões, a Lei 9.610/98, ao inserir o art. 28, caput, manifesta o seguinte dispositivo: "cabe ao autor o direito exclusivo de utilizar, fruir e dispor da obra literária, artística ou científica". 
A Constituição da República (1988) eleva, ainda, o direito de exclusividade dos direitos autorais a status de garantia fundamental. Tal como indicado em seu Art. $5^{\circ}$, inciso XXVII, "aos autores pertence o direito exclusivo de utilização, publicação ou reprodução de suas obras, transmissível aos herdeiros pelo tempo que a lei fixar".

Cunha Filho (2000) chama a atenção para o fato de que "com o acelerado desenvolvimento tecnológico, novas modalidades de exploração são constantemente criadas, o que 'fragiliza' a proteção patrimonial dos criadores". (CUNHA FILHO, 2000, p.92)

Uma corrente minoritária, como Souza (2003), afirma que, além do direito pessoal (moral) e real (patrimonial), os direitos autorais ainda se classificam como direito das obrigações a partir do momento em que as partes, por atos voluntários, assinam um acordo que gera uma obrigação.

Diante da admissão de parte patrimonial do Droit d'auteur e da concepção do copyright é possível que o autor transfira os seus direitos por meio de sucessão, cessão, concessão e licença estabelecida por contrato entre as partes como qualquer outro direito de propriedade (DUARTE; PEREIRA, 2009). A sucessão cabe tanto aos direitos morais quanto aos direitos patrimoniais. Entretanto, é importante ressaltar, com relação aos direitos patrimoniais, que os sucessores só poderão dispor dos direitos herdados durante o período que a lei nacional proteger. No caso do Brasil, a lei protege durante 70 anos e a contagem do prazo se inicia no ano subsequente à morte do autor, conforme consta no art. 41 da lei. (BRASIL, 1998). A cessão, a concessão e as licenças cabem somente aos direitos patrimoniais, tendo em vista que os morais são intransmissíveis.

A cessão se caracteriza pela transferência definitiva da titularidade da obra intelectual. Ou seja: é como um contrato de compra e venda, e o autor, antes detentor original dos direitos, não poderá mais decidir sobre a divulgação ou utilização de sua obra. A concessão, que possui caráter limitado, é um meio de garantir ao autor um monopólio sobre a utilização da sua obra, podendo, através da sua comercialização, obter um retorno financeiro "é uma autorização dada pelo autor 
para que um terceiro se valha da obra, com exclusividade ou não, nos termos da autorização concedida" (PARANAGUÁ, BRANCO, 2009, p.94). A licença dos direitos autorais se configura apenas como uma autorização de uso, onde não há a transferências dos direitos patrimoniais da obra, sendo temporária e ainda podendo ser gratuita ou onerosa.

A diferença entre a concessão e a licença é sutil. Enquanto a concessão envolve todos os direitos patrimoniais, a licença determina exatamente as condições em que a obra será licenciada. Assim, o contrato de concessão é como um contrato de aluguel amplo, pois apesar de não transferir a titularidades concede ao "locatário" todos os direitos autorais patrimoniais do autor. A licença será mais explorada na seção 2.4 a seguir, que trata do direito autoral no acesso aberto à literatura científica.

\subsection{O direito autoral no acesso aberto à literatura científica}

Nos últimos anos, em razão do movimento em favor do acesso aberto e das abordagens a ele relacionadas, tornou-se possível a pesquisadores de todo 0 mundo o auto-arquivamento das publicações dos resultados de suas pesquisas em meio eletrônico em uma variedade de locais, desde sites pessoais até repositórios institucionais. Isso porque trabalhos publicados em veículos que têm acesso controlado pelos detentores dos direitos de cópia permanecem atrás de barreiras que permitem seu acesso somente por pessoas ou instituições autorizadas. (OPPENHEIM, 2008, p. 1964).

Sem dúvida, o direito autoral se destaca como tema de grande importância nesse contexto, uma vez que é o responsável por regular o nível de acesso à informação publicada formalmente. Dessa forma, será visto nesta seção o Movimento que ganhou repercussão no mundo e que tem como escopo garantir o Acesso Aberto à literatura científica.

\subsubsection{O acesso aberto à literatura científica}

Considerado por muitos como um dos veículos mais relevantes de comunicação entre pesquisadores - na verdade, essa relevância varia dentro das 
divisões de conhecimento - o periódico científico está no cerne dessa discussão. Isso porque tem se constituído no principal elemento de discórdia entre pesquisadores e editores, no que concerne a tornar disponíveis resultados de pesquisas em veículos de acesso aberto.

Parece desnecessário introduzir discussão detalhada a respeito do acesso aberto, tendo em vista a abundante literatura já existente sobre a questão. Considera-se, portanto, que aspectos históricos ou mesmo conceituais não são requeridos aqui. Desse modo, centra-se a discussão nas questões que envolvem o direito autoral no contexto do acesso aberto. Nesse sentido, vale a pena chamar a atenção - embora trate-se de documento amplamente conhecido - para o que ficou estabelece a Bethesda Statement on Open Access Publishing. Ou seja, a definição do que é uma publicação de acesso aberto, que significa dizer que autores e detentores de direitos autorais devem assegurar a qualquer usuário:

1. Direito livre, perpétuo e irrevogável de acesso a seus trabalhos. Licença para copiar, usar, distribuir, transmitir e exibir trabalhos publicamente, elaborar e distribuir trabalhos derivados em qualquer meio digital para qualquer propósito responsável sujeito a atribuição apropriada de autoria, assim como fazer um número pequeno de cópias impressas para uso pessoal.

2. Uma versão completa do trabalho e de todo material suplementar - incluindo uma cópia da licença citada no item 1 - em formato digital apropriado, deve ser depositada, imediatamente após a publicação inicial, em pelo menos um repositório online que seja mantido por uma instituição acadêmica, uma sociedade cientifica, uma agência governamental ou outra instituição bem estabelecida que busque permitir o acesso aberto, a distribuição irrestrita, a interoperabilidade e o arquivamento em longo prazo. (Tradução da autora)

Como é possível observar, embora não explorando mais de uma década de discussão a respeito dessa definição, trata-se, sem dúvida, de uma das mais importantes mudanças no sistema de comunicação científica. Mais que isso, requer novas discussões a respeito das questões do direito autoral.

Outra questão que vale a pena mencionar, dado o foco do presente estudo, são as duas estratégias definidas quando da Budapest Open Access Initiative 
(BOAI), nomeadamente, Via Verde e Via Dourada. O enfoque, no caso deste estudo é a Via Verde (mais especificamente os repositórios institucionais), por ser a estratégia que mais fortemente colocou em cheque os modelos tradicionais de transferência de direito autoral. Isso porque, antes do movimento do acesso aberto havia, de fato, transferência de direitos. Depois do movimento ocorre a regulamentação do tipo de uso, sem o instituto legal da transferência de direitos de propriedade intelectual.

\subsubsection{Repositórios institucionais de acesso aberto (Via Verde)}

Ao comentar os dois caminhos para a o Acesso Aberto, Harnad (2005) lembra que

(1) na "via dourada" - da publicação em acesso aberto -, os periódicos oferecem acesso aberto de seus artigos (seja cobrando o autor/instituição para a arbitragem/publicação de trabalhos realizados em vez de cobrar a instituição/usuário para acessar artigos recebidos, ou simplesmente fazendo sua edição online gratuita para todos); (2) na "via verde" - do auto-arquivo em acesso aberto -, autores fornecem seus próprios artigos publicados em acesso aberto, fazendo seus próprios E-prints livres, para todos.

Suber (2012, p. 53), outro renomado e proeminente defensor do acesso aberto, ratifica as palavras de Harnad. Assim, a via verde no âmbito do movimento do acesso aberto se refere ao depósito de publicações científicas em repositórios institucionais de acesso aberto, onde ficarão disponíveis para pesquisa e uso.

De acordo com Leite (2009, p. 20) os repositórios institucionais são voltados à produção intelectual de uma instituição, especialmente de universidades e institutos de pesquisa. O autor acrescenta, ainda, que o conceito de repositório não é inovador, embora a inovação esteja relacionada às funções que os repositórios introduziram na comunicação científica. Dentre estas, o depósito da produção dos pesquisadores em sites de suas instituições, que amplia significativamente o acesso a essa informação, é uma das mais relevantes.

Crow (2002, p. 3) afirma que os repositórios institucionais são aqueles institucionalmente definidos, científicos ou academicamente orientados, cumulativos e perpétuos (permanentes) e abertos e interoperáveis. Para o autor, os repositórios institucionais têm o escopo de ser o guardião da investigação original da produção 
intelectual gerada pela instituição. Além disso, podem exercer a função de disponibilizar material produzido por outra instituição com o fim de dar visibilidade e facilitar a recuperação do documento de interesse da sua instituição. Para tanto, o repositório institucional deve ser interoperável, uma vez que tem o fim de proporcionar acesso por meio de ferramentas de busca.

Igualmente, é importante mencionar a definição por Souto e Oppenhheim (2008, p.139) que ensinam que, no modelo de Via Verde, existe a liberdade para que o autor busque, através de incentivos, depositar suas produções em meios que garantam o livre acesso ao conteúdo, tais como repositórios institucionais e em sítios dos autores na internet. A figura 4 ilustra o fluxo das duas estratégias. Já no modelo de Via Dourada, os periódicos de acesso aberto são criados sob o paradigma do livre acesso ao conteúdo publicado.

É importante destacar que o autor, como titular do direito de uso da obra, não pode ser obrigado a publicar sua pesquisa em veículos que não deseje. Nesse sentido, Suber (2012, p. 79) explica que

Não existe a obrigação de publicação pela via dourada em lugar algum; todas as políticas que obrigam publicação são de via verde. Infelizmente, todavia, muitas pessoas erroneamente acreditam que toda política de acesso aberto é de via dourada e, portanto, confundem obrigação de publicar pela via verde, com obrigação de publicar pela via dourada e acabam levantando objeções que apenas seriam aplicadas a obrigação de publicar pela via dourada. (tradução da autora)

O que se pode concluir dessa discussão é que as questões relacionadas com a Via Verde requerem, de fato, discussão e decisões contundentes sobre direito autoral, especialmente no que concerne ao surgimento de novas abordagens para uso da obra intelectual. Nessa perspectiva, o projeto Digital Repositories Infrastructure Vision for European Research (DRIVE) ${ }^{9}$, embora tenha sido finalizado

9 Esse projeto, financiado pela União Europeia, teve como objetivo auxiliar no estabelecimento e desenvolvimento da infra-estrutura de repositório de acesso aberto europeu. Disponível em: < http://www. driver-support.eu/>. Acesso em: 2 de out. 2015 
em 2009, considerou os direitos de propriedade intelectual como um dos fatores de sucesso para a implementação do repositório institucional.

Figura 4 - Vias verde e dourada para o acesso aberto

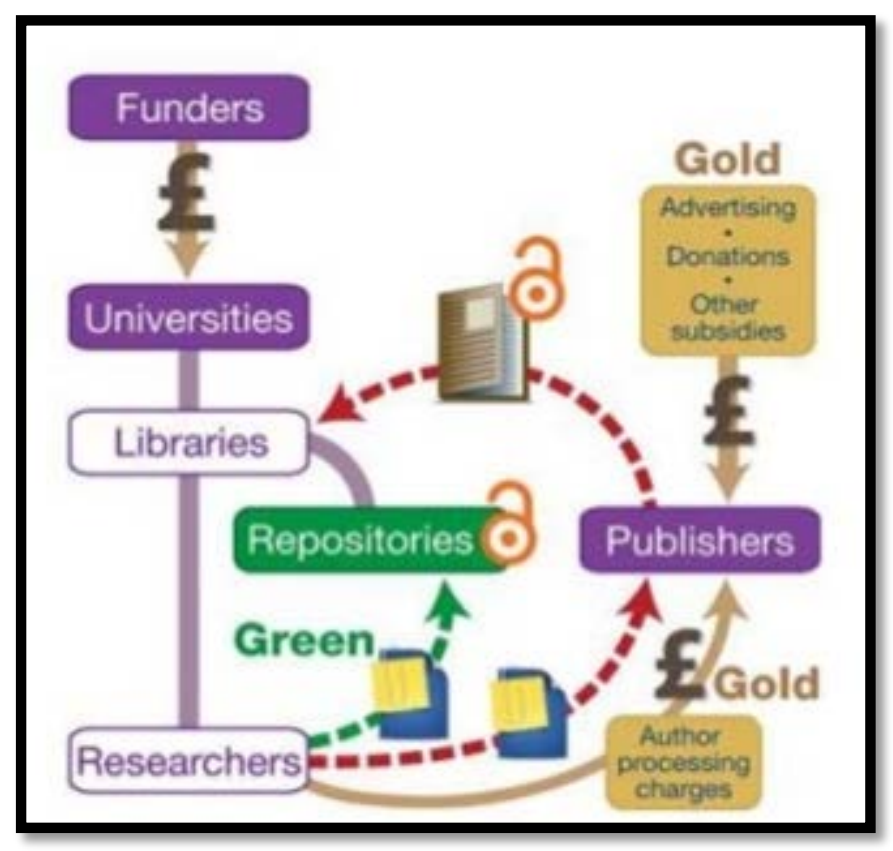

Fonte: <http://www.hefce.ac.uk/rsrch/oa/whatis/>. Acesso em: 15 out. 2015.

\subsubsection{Direito autoral: copyleft e creative commons}

Lessig (2004, p.4) relata o caso da família Causby, que ingressou com uma ação na justiça, em 1945, contra o governo dos Estados Unidos, alegando que sua propriedade estava sendo invadida por aviões, o que causava danos à família uma vez que as suas galinhas ficavam assustadas com o barulho do avião, batiam na cerca e morriam. A referida ação utilizou como fundamento os doutrinadores Blackstone, Kent e Coke que afirmaram que a propriedade do terreno alcançava "uma extensão indefinida para cima". A Suprema Corte aceitou ouvir o caso dos Causby, mas reconheceu que a ação estava motivada em doutrina antiga na Common Law, em que "a extensão da propriedade se estendia até a periferia do Universo". Com isso, o Juiz Douglas proferiu a seguinte sentença

A doutrina não cabe no mundo moderno. O ar é uma via pública, como o Congresso declarou. Se assim não fosse, todo vôo 
transcontinental seria alvo de infinitos processos por invasão. $\mathbf{O}$ bom senso fica revoltado diante de tal idéia. Reconhecer tais apelos privados pelo espaço aéreo iria obstruir esses caminhos, interferindo com seu controle e desenvolvimento para o bem público, e transferindo para a propriedade privada o que apenas o público poderia ter como um direito justo. (Grifo nosso)

Esse relato evidencia que o interesse coletivo irá ou, pelo menos, deverá prevalecer sob o interesse particular ante uma questão de bom senso. O autor acrescenta, ainda, que o "bom senso precisa se revoltar", e conclui que é necessário agir para a criação de uma cultura livre. Lawrence Lessig é o co-criador da licença creative-commons, que será mais explorada na próxima seção.

O caso dos Causby é um exemplo de que o direito que rege uma sociedade deve ser moldado consoante a evolução de uma nação. Isso porque o caso relata que, embora a doutrina utilizada para defender o caso já ser consolidada, a invenção do avião fez com que o entendimento jurídico anterior fosse invalidado por uma sentença, de um parágrafo, baseada no bom senso e no interesse da coletividade.

É possível, portanto, afirmar que o ordenamento jurídico de um país deve acompanhar a evolução da sociedade. Foi com base nesse entendimento que foram criadas licenças públicas para regulamentar o uso do direito de propriedade intelectual tendo em vista o avanço da tecnologia e o advento da internet, que ampliou e facilitou o acesso à informação em todo o mundo.

O direito à propriedade intelectual, restritivo por legislações de direitos autorais, passou a ser, então, um grande impedimento ao acesso à informação, o que motivou a criação de licenças públicas, visando a regular o uso da obra intelectual de forma simples e eficaz e, principalmente, motivada pelo bom senso. Dentre as licenças públicas que surgiram nesse cenário é importante mencionar as licenças Copyleft, e Creative Commons.

\section{Licença copyleft}

A licença copyleft originou-se nos Estados Unidos em meados da década de 1980, com o surgimento do software livre. A ideia era fazer uma alusão ao copyright de forma oposta, como um trocadilho com duplo sentido, tornando-o próximo à cópia 
autorizada. Isso porque propõe "que o autor libere, desde o primeiro licenciamento, os direitos de uso, reprodução, distribuição e, eventualmente, de alteração de sua obra a qualquer interessado", conforme Paranaguá e Branco (2009, p.110).

Santini (2008, p. 97) define o copyleft como um acordo elaborado à luz da política de copyright (ou outro contrato firmado entre autor e editor para proteção dos direitos autorais), só que com duas peculiaridades que o fazem ganhar um nome especial. A primeira permite ao autor autorizar a derivação de trabalhos subsequentes de um trabalho original, sem a permissão do proprietário protegido por direitos autorais. A segunda permite ao autor conceder a autorização para trabalhos derivados, requerendo que estes também sejam autorizados pela licença de copyleft do original.

Moniz e Cerdeira (2004, p.68) resumem a ideia conceitual da licença, afirmando que "o copyleft licencia os direitos do copyright, porém exige que os licenciados façam a devida referência ao autor da obra e façam o mesmo licenciamento da redistribuição das cópias". Além disso, acrescentam Lemos et al (2009, p. 151), os contratos copyleft visam a criar, também, o conceito de direito moral de paternidade dentro do instituto copyright.

\section{Creative Commons}

A licença Creative Commons foi criada pelo professor Lawrence Lessig da Universidade de Harvard, e seu objetivo foi "expandir a quantidade de obras criativas disponíveis ao público, permitindo criar outras obras sobre elas, compartilhando-as" (BRANCO; BRITTO, 2013, p.65). Esse processo se realiza por meio de licenças jurídicas que permitem o acesso às obras pelo público sob condições mais flexíveis. No site do Creative Commons no Brasil a equipe afirma que o interesse deles é substituir "todos os direitos reservados" por "alguns direitos reservados" ou, até mesmo, por "nenhum direito reservado". 
O sucesso dessa licença deve-se, entre outras coisas, como demonstrado no vídeo de apresentação do site ${ }^{10}$, ao fato de aproximar o autor do leitor. Ou seja, retira os intermediários, advogado e editor, do processo de comunicação. Por isso, a iniciativa investe ao máximo na linguagem, no suporte, na infraestrutura e, principalmente, na comunicação.

Segundo Paranaguá; Branco (2009, p. 115), o uso da licença Creative Commons permite que o autor tenha alguns direitos reservados e não todos, assegurando que a sociedade possa utilizar sua obra segundo as licenças adotadas por ela. Dessa forma, tanto os direitos do autor ficam protegidos, quanto o direito da sociedade em ter acesso à cultura fica resguardado.

São quatro as principais licenças Creative Commons. A primeira é a licença de atribuição, opção obrigatória em que o autor autoriza a cópia, a distribuição e a utilização da obra. A segunda refere-se ao veto ao uso comercial e envolve as mesmas autorizações da licença anterior, porém tem-se a proibição do uso para fins comerciais. A terceira diz respeito à não permissão de obras derivadas, no sentido em que a obra não pode ser alterada ou editada sem o consentimento do autor. Finalmente, a quarta licença diz respeito ao compartilhamento pela mesma licença: adota o espírito do copyleft, dado que a obra pode ser utilizada para criar obras derivadas desde que, ao serem distribuídas, sejam licenciadas da mesma forma.

Por fim, o Creative Commons é uma iniciativa que procura efetivar a disseminação dos trabalhos dos mais diversos tipos de artistas, criadores e detentores de direitos. Assim, o autor pode optar por licenciar (dispor para uso) seu trabalho sob um contrato específico resultado da combinação entre as quatro licenças que atendam melhor a seus interesses, podendo escolher entre as diversas opções pré-existentes. (LEMOS; BRANCO JUNIOR, 2007, p. 15)

É possível afirmar que a licença creative commons - assim como as demais licenças - trata de um contrato jurídico firmado entre o autor e o usuário. Esse

${ }^{10}$ Disponível em: < https://br.creativecommons.org/licencas/> . Acesso em: 10 out. 2015. 
contrato é unilateral, uma vez que apenas o autor estabelece as regras de uso (figura 5). Ou seja: as regras são acordadas sem quaisquer reivindicações do usuário da informação (público). Além disso, como afirmam Lemos e Branco Junior (2007, p. 16), as legislações de direitos autorais continuam vigentes, haja vista que o que se tem, por meio das licenças públicas, "é a garantia de se poder usar a obra alheia dentro das autorizações concedidas".

Figura 5 - Modelos de negociação de direitos autorais

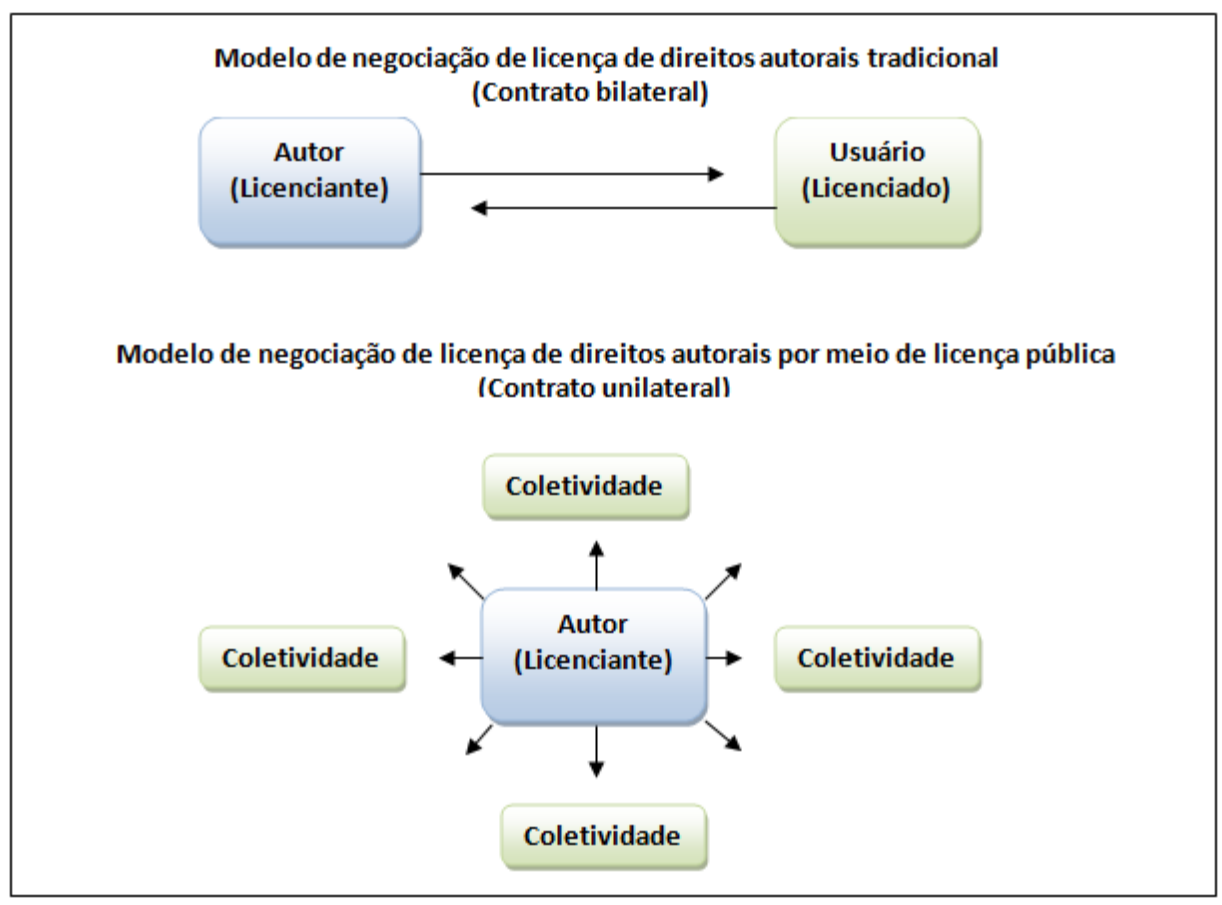

Fonte: a autora (2015)

\subsection{Política pública de acesso aberto à literatura científica}

Países de línguas latinas apresentam dificuldades com relação a alguns termos das ciências políticas, como é o caso da própria palavra política. Os países de língua inglesa, por exemplo, diferenciam facilmente os termos politics e policy e este trabalho leva em conta esta diferenciação $O$ termo Politics é conceituado por Bobbio (2002, p.49) como "atividade humana ligada à obtenção e manutenção dos recursos necessários para o exercício do poder sobre homem". O autor exemplifica o conceito com a seguinte frase: "a política de Brasília está distante das necessidades do povo". Como esse estudo trata de ações concretas, preferiu-se conceituar as 
traduções dos termos para esclarecer o que será abordado, isto é, policy, que, segundo Secchi (2013, p. 1), diferentemente de politics é a política concreta que guarda relação com orientação para decisões e ações.

O termo política pública está vinculado, portanto, a este conceito de política, na medida em que trata do conteúdo das decisões políticas, do processo de construção e da atuação dessas decisões. A política pública é uma "orientação à atividade ou passividade de alguém" conforme observa Secchi (2013, p.2). Outra questão que chama a atenção é que a política pública trata de um problema público, e não se confunde com políticas governamentais, as quais apenas compõem um subgrupo das políticas públicas e que atualmente recebe mais atenção na literatura da área. É importante ressaltar que a abordagem estadística ou estado-cêntrica (state-centered policy-making) considera que as políticas públicas são emanadas apenas de um ator estatal, confundindo-as, assim, com políticas governamentais.

Contudo, neste trabalho entendem-se as organizações privadas, organizações não governamentais, organismos multilaterais e redes de políticas públicas (policy networks) como parte das políticas públicas, juntamente com os atores estatais. Essa interpretação coaduna-se com a abordagem multicêntrica ou policêntrica defendida por Rhodes (1997 apud SECCHI, 2013, p. 3) e Hajer (2003, p.190). A figura 6 ilustra essa abordagem.

Figura 6 - Políticas públicas e políticas governamentais

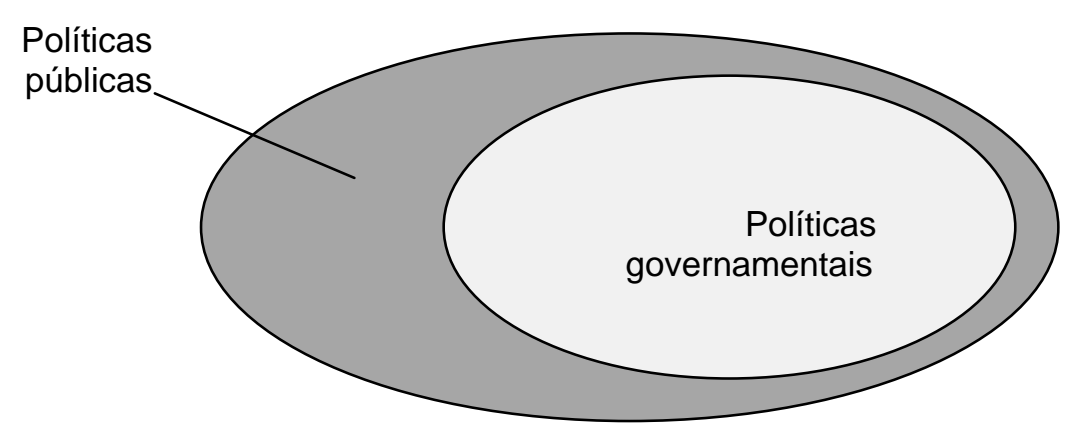

Fonte: Secchi (2013, p. 5)

Ao longo do tempo muitos estudiosos buscaram compreender o processo de construção de uma política. Esses estudos resultaram em diferentes teorias acerca 
do processo de formação da política pública. A seguir, são apresentadas seis abordagens de autores relevantes para a discussão dessas teorias.

Primeiramente, Acemoglu e Robinson (2012) esclarecem os motivos que levam alguns países ao êxito econômico e outros à pobreza de sua população por meio das características de suas instituições. Seu argumento é que a principal causa dos diferentes graus de desenvolvimento econômico das nações não é a economia em si, mas a política. Os sistemas políticos adotados pelas diferentes nações são decisivos para a determinação de seu sucesso ou fracasso econômico. Isso porque as instituições atuantes no sistema favorecem ou prejudicam a atividade econômica do país. Os países mais desenvolvidos economicamente apresentam instituições políticas que estimulam a produção agrícola e industrial além de favorecerem a inovação tecnológica e científica. No caso dos países menos desenvolvidos economicamente, as instituições políticas, que devem fomentar a atividade econômica, na verdade perpetuam um sistema que favorece aqueles que controlam os fatores reais de poder e aumentam cada vez mais a desigualdade social de sua população.

Em segundo lugar, Zahariadis (2007) defende a teoria dos fluxos múltiplos nos processos de criação das políticas públicas. No bojo dessa teoria, são identificados três fluxos dentro do sistema político, quais sejam: problemas, políticas públicas (policies) e política (politics). Todas elas são independentes e possuem suas próprias particularidades. Contudo, as instituições são capazes de juntar esses três fluxos em momentos críticos, quando surge a oportunidade, para potencializar as chances de que certa política pública seja criada e adotada pelo Estado. A teoria dos fluxos múltiplos se assemelha à Teoria dos Sistemas, por considerar a análise da tomada de decisão num contexto sistêmico (resultante de diversos fatores), semelhante à Teoria do Caos. O resultado da atuação dos múltiplos fatores no processo não é determinado, ou seja, não pode ser previsto.

Em terceiro lugar, deve-se considerar também o modelo apresentado por Kingdon (2011), que considera as organizações governamentais como "anarquias organizadas", onde a ambiguidade predomina. Tais organizações são caracterizadas 
por três propriedades. A primeira compreende a participação dinâmica, onde a atuação dos agentes, governamentais ou não, é "fluida" e as mudanças de pensamentos são frequentes e variam a cada decisão tomada. A segunda diz respeito a preferências problemáticas, em que os tomadores de decisão não são claros no que querem e em seus objetivos. Finalmente, há a tecnologia incerta, que é uma forma desconhecida de como as informações e insumos apresentados são transformados ao longo do processo decisório.

Como quarta abordagem, o estudo de Bonafont (2004) sobre Redes de Políticas Públicas defende que o processo de criação e desenvolvimento de uma política pública não se limita apenas à mobilização de grupos sociais. Mais que isso, leva em conta a forma pela qual tais grupos se institucionalizam nas relações de poder entres os atores ao longo do tempo, enfatizando a autonomia das instituições na vida política. Dessa forma, as instituições têm papel de ator imprescindível para o estudo e o entendimento dos processos políticos, visto que é possível explicar todo o processo a partir da ideia de que é o resultado da atuação de indivíduos racionais em prol de interesses particulares. As instituições têm autonomia e defendem interesses e ideias que caracterizam o coletivo que representam, dispondo de mecanismos para influenciar em um nível mais amplo do que os indivíduos.

Em quinto lugar, o surgimento da Análise de Redes de Políticas Públicas (Policy Network) tem a finalidade de identificar diversas maneiras de intermediação de interesses entre setores da sociedade de um país ao longo do tempo. É, de forma geral, utilizada para avaliar os aspectos de relacionamentos institucionais envolvidos no processo de desenvolvimento de políticas públicas. Sua definição é um conjunto de relações relativamente estáveis entre atores públicos e privados que interagem por meio de uma estrutura hierárquica e interdependente, para alcançar objetivos comuns referentes à política. Essa abordagem busca elucidar os motivos pelos quais os diversos países adotam estratégias diferentes para os mesmos problemas, apesar da homogeneização que organismos internacionais e blocos econômicos proporcionam, num contexto global. Também procura explicar o processo de elaboração de políticas públicas como consequência de um processo de troca e negociação entre entes públicos e privados, interagindo com o objetivo de 
intercambiar informações e recursos num marco institucional concreto. A constante interação entre os entes públicos e privados possui destaque nessa abordagem, ressaltando a "interdependência" e a cooperação necessária entre esses agentes para a gestão pública.

Além das cinco relevantes teorias supramencionadas, é importante destacar o trabalho de Sabatier e Weible (2007) sobre o Sistema de Coalizões de Advocacy ${ }^{11}$ (Advocacy Coalition Framework - ACF). Tal teoria estuda o processo de políticas públicas considerando os subsistemas de política como foco da análise, em perspectivas de longo prazo, nas quais o crescente número de atores envolvidos permite que estes se agrupem em coalizões e que o desenho final das políticas reflita os anseios das coalizões eventualmente formadas. É o caso da Advocacy Coalition Framework (ACF).

\subsubsection{Advocacy Coalition Framework (ACF)}

O modelo de coalizões da ACF proposto por Sabatier e Jenkins-Smith (1993) visa a análise das mudanças nas políticas públicas, destacando o papel da informação no processo de disputas que envolvem múltiplos agentes em esferas distintas e diferentes níveis de governo (SABATIER; WEIBLE, 2007). O modelo foi desenvolvido a partir de estudos de casos nos EUA, com um foco particular sobre a política ambiental. Os autores adaptaram o modelo para replicar sua aplicação em casos fora dos EUA e em outros domínios políticos (CAIRNEY, 2013). Sabatier (1988, p.189) define o ACF como

\footnotetext{
${ }^{11}$ Uma pesquisa realizada no Google Scholar, em português, com o termo "advocacy" mostrou que os trabalhos recuperados nas mais de 30 primeiras ocorrências não traduziram o termo. Então, optou-se por não traduzir o termo advocacy neste trabalho. Entretanto, o estudo da LIBARDONI (2000) explica que "definições e os significados da advocacy têm variado no tempo e vêm sendo formulados a partir de como são compreendidos a política e o poder. Advocacy tem origem na palavra advocare, do latim, que significa ajudar alguém que está em necessidade. Em inglês, provém do verbo to advocate. Mas como advocacia e advogar, em português, referemse fundamentalmente a atividades de natureza legal ou jurídica, preferimos traduzir advocacy como defender e argumentar em favor de uma causa, uma demanda ou uma posição. Isso porque advocacy tem um significado mais amplo, denotando iniciativas de incidência ou pressão política, de promoção e defesa de uma causa e/ou interesse, e de articulações mobilizadas por organizações da sociedade civil com o objetivo de dar maior visibilidade a determinadas temáticas ou questões no debate público e influenciar políticas visando à transformação da sociedade." Disponível em
} 
(representantes eleitos e funcionários públicos, líderes de grupos de interesse, pesquisadores, intelectuais e etc.) que (i) compartilham determinado sistema de crenças: valores, idéias, objetivos políticos, formas de perceber os problemas políticos, pressupostos causais e (ii) demonstram um grau não trivial das ações coordenadas ao longo do tempo. A coalizão é composta por atores públicos e privados de diversas organizações e de todos os níveis de governo, que compartilham certo conjunto de crenças e valores e que almejam atingir esses objetivos, por meio de ações coordenadas ao longo do tempo.

Sabatier e Jenkins-Smith (1993) desenvolveram o ACF para descrever e explicar um ambiente de formulação de políticas, que contém vários atores e níveis de governo, produz decisões apesar dos altos níveis de incerteza e ambigüidade, leva anos para se transformar decisões em resultado e elabora processos de políticas de maneiras muito diferentes. Algumas questões envolvem disputas intensamente politizadas que contêm muitos atores. Outras são tratadas como técnicas e processados rotineiramente, em grande parte por especialistas em política, fora dos holofotes públicos. A figura 7 ilustra os processos de criação de políticas públicas a partir do foco das coalizões, com base na teoria da ACF.

Figura 7 - Diagrama da ACF desenvolvido por Sabatier

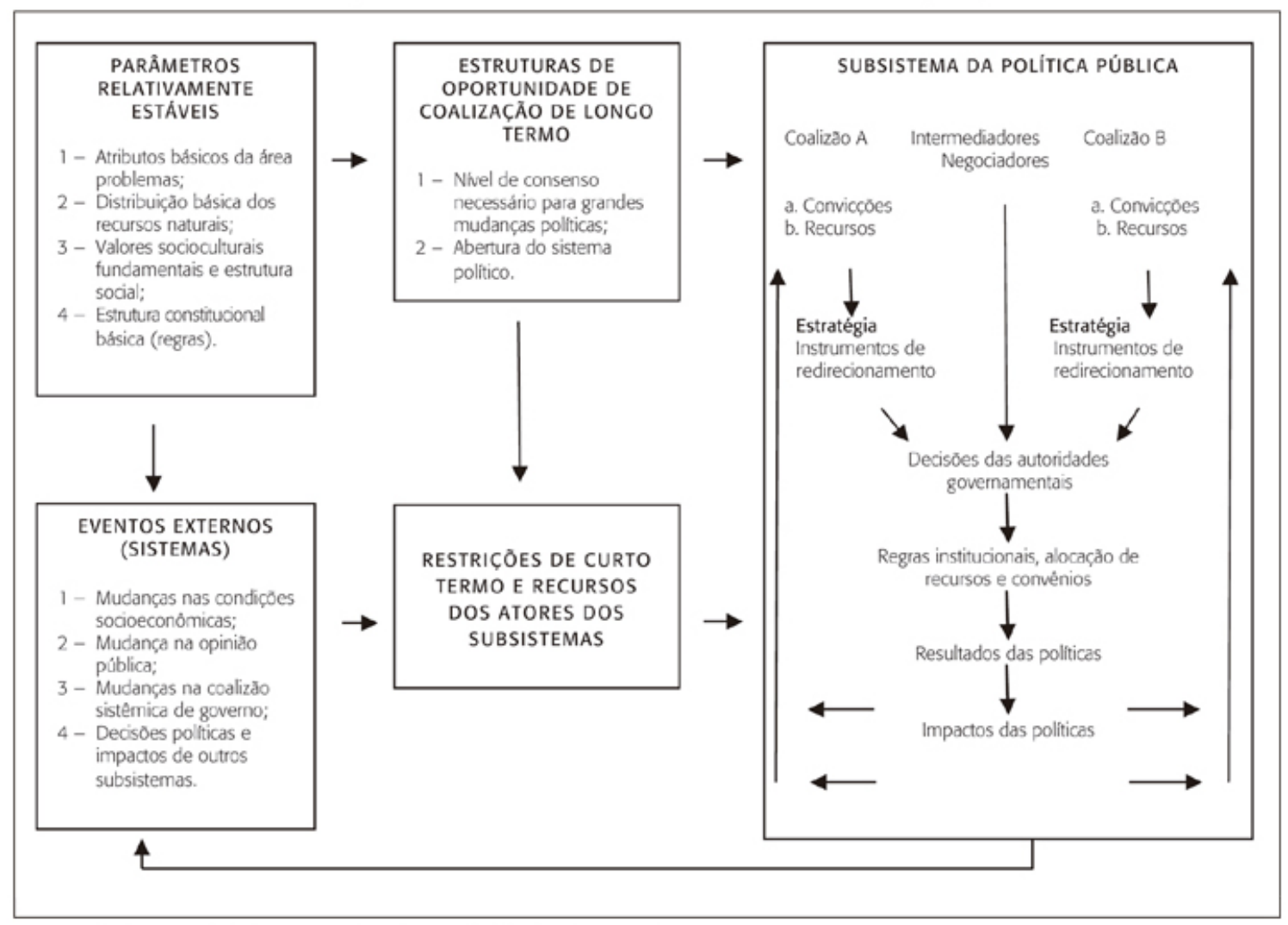

Fonte: Sabatier e Waible (2007, p. 202) traduzido por Oliveira (2011, p.18) 
Sabatier e Jenkins Smith apontam que crenças, valores e idéias são dimensões importantes no processo de formulação de políticas públicas. Assim, cada subsistema que integra uma política pública é composto por um número de coalizões de advocacy que se distinguem pelos seus valores, crenças e idéias e pelos recursos de que dispõem. (SOUZA, 2006, p.20-45)

O modelo supõe que as principais partes interessadas tendem a ser especializadas em um sistema de política, tendendo a buscar alianças com outras partes interessadas, que tenham crenças similares. As partes interessadas na mesma coalizão tendem a envolver-se em um "grau não trivial de coordenação" (WEIBLE; SABATIER, 2009, p. 99).

O modelo também supõe que as opções dos stakeholders são delimitadas por restrições que organizam a percepção do que está em jogo na política e quais são os ganhos e perdas associados às alternativas políticas. É a força e a natureza dessas crenças que explicam a relativa estabilidade dessas coalizões dentro de um subsistema de política, que, por sua vez, explica a longa duração das políticas dinâmicas que caracterizam um determinado sistema político. (CAIRNEY, 2013).

Como é possível notar, mudanças na dinâmica da política podem ser produzidas por três fontes diferentes. A primeira constitui-se das mudanças nos parâmetros sociais gerais do país em questão. A segunda diz respeito a acontecimentos políticos que afetam a distribuição de recursos dentro do sistema de política. A última refere-se ao impacto da produção das políticas. (BALBACHEVSKY, 2005, p.5).

A partir da teoria da ACF, cujo enfoque principal é a formação de coalizões e a mudança de políticas conforme o cenário político, é possível analisar o papel que o Movimento do Acesso Aberto desempenha na comunicação científica, no contexto do direito autoral. Isso porque o movimento representa ações que tomaram força a partir da formação de coalizões em prol do acesso aberto à literatura científica. 


\subsubsection{Coalizões: o contexto do acesso aberto}

Há dez anos, a Iniciativa de Acesso Aberto de Budapeste (Budapest Open Access Initiative - BOAI) desencadeou uma campanha mundial em prol do acesso aberto. Resultados de pesquisa realizada por Silva e Alcará (2009, p. 112) indicavam que o movimento de acesso aberto à literatura científica já era uma preocupação oficialmente registrada em vários países, ainda que com diferentes graus de desenvolvimento e diferentes formas de ação.

Dentre inúmeras iniciativas, surgiram organizações e coalizões em defesa do acesso aberto à literatura científica. $\mathrm{O}$ trabalho realizado no nível dessas coalizões mostrou-se crucial para o avanço do acesso aberto. Mais que isso, as próprias coalizões representam fatores de sucesso nesse contexto.

Para fins de exemplo do cenário internacional, o presente estudo mapeou coalizões como a Scholarly Publishing and Academic Resources Coalition (SPARC) e a Coalition of Open Access Policy Institutions (COAPI). No contexto brasileiro, não foi possível mapear coalizões tal como existem em outros países, nem mesmo organizações que tenham assumido a defesa do acesso aberto no país. Embora executivos do Ibict tenham liderado as questões do acesso aberto no país, a instituição não assumiu oficialmente posição de liderar coalizões.

\section{Scholarly Publishing and Academic Resources Coalition (SPARC)}

A implantação de políticas de acesso aberto nos Estados Unidos ganhou impulso por meio do esforço de duas organizações de defesa do acesso aberto: a SPARC - Coalização de Publicações Cientificas e Recursos Acadêmicos e a PK Conhecimento público. A SPARC foi fundada por Rick Johnson em 1998 e já conta com aproximadamente 800 instituições na América do Norte, Europa, Japão, China e Austrália. Seu objetivo primário tem sido melhorar a competição no mercado de revistas acadêmicas, mas com a Budapest Open Acess Initiative em fevereiro de 2002, o SPARC se tornou um advogado ativo do acesso aberto. (SCHEUFEN, 2014)

O trabalho do SPARC se concentra em três áreas chave. A primeira é a educação de stakeholders sobre problemas com a comunicação científica e as 
oportunidades de desempenhar papel relevante no alcance de mudanças positivas. A segunda relaciona-se com mudanças em políticas de advocacy que contribuem para o avanço da comunicação científica, reconhecendo que a construção do conhecimento (scholarship) é um componente "essencial, inseparável do processo de pesquisa". Finalmente, a incubação de novos modelos de publicação e de sustentabilidade que beneficiam os acervos de conhecimento constitui a terceira área chave.

\section{Coalition of Open Access Policy Institutions (COAPI)}

A Coalizão de Políticas Institucionais de Acesso Aberto reúne vários representantes docentes de universidades norte-americanas, desde as que já têm suas políticas de acesso aberto instituídas, às que ainda estão em processo de desenvolvimento de tais políticas. A coalizão foi criada com o objetivo de compartilhar experiências e informações e oferece uma coleção de boas práticas para inspirar as instituições a promoverem e implantarem o acesso aberto.

Trata-se de uma associação informal, composta por membros, afiliados e membros da comunidade; não há taxas para quem deseja juntar-se à coalizão, bastando apenas que o membro em potencial concorde com um conjunto de princípios que orientam a COAPI.

\subsubsection{Coalizões nacionais e o direito autoral}

Embora não tenha sido possível mapear coalizões de interesse do acesso aberto no Brasil, dados de consulta pública realizada pelo Ministério da Cultura brasileiro para revisar a Lei de Diretos Autorais permitem a identificação de coalizões útil para exemplificar sua relevância no processo de elaboração de políticas públicas. A análise dos documentos obtidos por meio da consulta, orientada pela teoria da ACF com vistas a identificar grupos de interesse envolvidos no tema, permitiu mapear a visão de quatro entidades que se manifestaram. Conhecer seus argumentos contribuiu para identificação e descrição do cenário brasileiro diante dos

direitos autorais na comunicação científica. São apresentados a seguir os 
argumentos dos quatro grupos identificados, sendo os dois primeiros contrários e os dois últimos a favor do anteprojeto de lei.

\section{Argumentos do ECAD}

Uma das manifestações mais veementes contra as alterações propostas à Lei 9.610/1998 é a do Escritório Central de Arrecadação e Distribuição (ECAD), que representa diversas associações de proteção ao direito de autor - compositores de música - e entidades diretamente interessadas no tema. Uma das preocupações do Escritório é a possibilidade de perda do direito dos autores de decidirem livremente sobre o uso de suas criações, criando a licença não voluntária que confere ao Presidente da República o poder (supremo) de autorizar em nome dos autores o uso de suas obras artísticas, literárias e científicas. Seguindo o processo expropriatório, o Poder Público, no lugar dos autores, determina o valor dos Direitos Autorais a serem pagos nessa situação ${ }^{12}$.

\section{Argumentos do SNEL}

O Sindicato Nacional dos Editores de Livros (SNEL) também manifesta sua insatisfação ao Ministério da Cultura, seguindo a linha de crítica ao Anteprojeto de lei que propõe mudanças à LDA. De acordo com sua análise "[...] o texto preocupou-se muito mais em estabelecer uma função social do direito de autor do que propriamente em dar-lhe a proteção como caberia neste sistema normativo." (BRASIL, 2010).

Dentre outras alegações o Sindicato argumenta que, na concessão de licenças não voluntárias, o texto não é claro o suficiente, não havendo critérios objetivos para a outorga de tais concessões, gerando incertezas para o meio artístico e intelectual.

As manifestações do ECAD e do SNEL ajudam sobremaneira na discussão do tema apresentado, que se mostra bastante polêmico. Contudo, tais entidades

12 Disponível em: <http://www.ecad.org.br/pt/quem-somos/oEcad/Paginas/default.aspx>. Acesso em: 10 set. 2015. 
representam grupos de interesses e coalizões cujas atividades econômicas seriam diretamente afetadas pelas questões em comento.

\section{Argumentos do IBPI}

Os argumentos do Instituto Brasileiro de Propriedade Intelectual (IBPI) mostram uma impressão bastante positiva em relação às alterações propostas pelo Ministério da Cultura à LDA/98. Por meio de Nota, o Instituto defende que o direito de autor não estaria separado dos demais direitos e garantias do sistema jurídico brasileiro. Como todo sistema de proteção de direitos existentes no ordenamento jurídico pátrio, o sistema de Direito Autoral precisaria estar em equilíbrio com os demais. Não haveria que se falar apenas em proteção aos autores e, muito menos, em proteção apenas dos interesses dos usuários das obras produzidas.

Também argumenta o IBPI que o Anteprojeto estaria de acordo com as convenções internacionais sobre propriedade intelectual, já que ambas preveriam o equilíbrio entre Direito Autoral e interesse coletivo, tais como acesso universal à cultura e desenvolvimento da educação. Além disso, a lista de uso livre de direito patrimonial sobre propriedades intelectuais, ou seja, o limite de livre exploração de obras por parte de seus autores, não ultrapassaria o rol apresentado pela Convenção de Berna.

Por fim, a Nota do IBPI menciona que a licença não voluntária seria um excelente avanço na legislação sobre direitos de autor no ordenamento jurídico brasileiro. O que poderia ser considerado como uma severa afronta a um direito fundamental, na verdade seria um mecanismo para a garantia da harmonização do direito do acesso público à informação.

\section{Coalizão da Rede pela Reforma}

Considerando que a Rede pela Reforma é a reunião de diversas entidades da sociedade civil, considera-se que, diferentemente das outras três organizações citadas, se adéqua ao conceito de coalizão tratado no presente estudo. A Rede é formada por organizações tais como a Associação Nacional de Pós-Graduação e Pesquisa em Educação (ANPEd), a Comunidade Brasileira de Recursos 
Educacionais Abertos (REA) e a União Nacional dos Estudantes (UNE). Constituiuse com o objetivo de discutir o Anteprojeto de lei que prevê mudanças para a Lei de Direitos Autorais. Após a realização de debates entre os participantes interessados, foi alcançado o consenso em alguns dos pontos de revisão.

A Rede entende como necessário o fim do limite à reprodução parcial ou integral de obras, desde que para fins privados, tentando garantir o fim social do acesso à cultura e à informação. A flexibilização da utilização e reprodução de obras culturais, artísticas e intelectuais, desde que respeitadas as condições de interesse coletivo e relevância social, seria de extrema necessidade para o desenvolvimento educacional e cultural do país. Seu argumento está baseado em que a legislação brasileira estaria defasada em comparação ao resto do mundo, sendo que, nesse caso, seria um dos únicos países que ainda mantém tal restrição de reprodução. Defende, ainda, o uso de obras não apenas para uso privado, mas também para fins didáticos, por parte de professores e educadores na elaboração de suas aulas, sem ter que se preocupar com autorização expressa do autor e nem arcar com os custos referentes aos direitos autorais.

\subsubsection{Política Institucional de Acesso Aberto}

Importante notar, como já mencionado no início desta seção (2.5 Política pública de acesso aberto à literatura científica), que a política de informação, como assegura a autora, é formada por regulamentos e posições doutrinárias, além da legislação. Portanto, a política de informação de uma instituição é tratada como um dos regulamentos que compõem a política pública de informação de um país. Esclarece-se, então, que esta seção aborda a política de informação no âmbito da instituição que tem o escopo de instituir o acesso aberto à literatura científica, no contexto do direito autoral. Como definido por Braman (2011, p.3), a política de informação é composta de leis, regulamentos e posições doutrinárias que envolvem a criação de informação, processamento, acesso e uso. 
No âmbito da BOAl, foram estabelecidas novas metas ${ }^{13}$ a serem atingidas nos próximos dez anos. Dentre elas, há a recomendação de que toda instituição de ensino superior deve ter uma política que assegure o depósito das versões de artigos científicos revisados por pares, em repositório designado pela a instituição. Nesse contexto, Suber (2012, p. 57-58) ressalta que a existência de uma política de acesso aberto é de grande importância para o povoamento de repositórios institucionais. O autor verificou que instituições sem políticas específicas contam com aproximadamente 15\% de depósitos voluntários, ao passo que instituições que incentivam e solicitam o depósito podem chegar a 100\% após alguns anos.

No mesmo sentido, Friend (2013, p. 15) entende que para se conseguir alcançar o acesso aberto, e todos os benefícios que tal iniciativa pode proporcionar, é necessária uma estratégia que preveja mudanças estruturais, legais e comerciais. Significa dizer que se trata de uma política que resulte na percepção do acesso aberto como inerente à pesquisa e ao ensino na instituição. Suber (2012, p. 58) acrescenta que o desconhecimento e a falta de entendimento por parte dos autores constituem obstáculo maior ao acesso aberto do que as próprias correntes contrárias ao tema, seja de outros autores, seja de editoras. Para Cohen et al (2013, p. 10) o principal aspecto de uma política institucional voltada para o acesso aberto é a educação para o tema. Nas palavras dos autores,

A chave para a advocacia eficaz para as políticas de acesso aberto é
a educação. Colegas de Departamentos, mesmo em Departamentos
da biblioteca, podem não ser tão familiarizados com a publicação de
acesso aberto quanto nós pensamos. Se eles não são totalmente
esclarecidos sobre os fatos, eles podem resistir ou rejeitar uma ação
formal relacionada ao acesso aberto. (tradução nossa)

Em estudo desenvolvido na Universidade do Minho, em Portugal, Príncipe et al. (2012, p. 07) identificaram os três principais motivos que levam aos autores europeus a não depositarem suas obras em repositórios institucionais. O primeiro seria o entendimento de que não existiria um repositório institucional ou temático adequado para tanto. O segundo, haveria o receio de violação dos direitos autorais.

${ }^{13}$ Disponível em: <http://www.budapestopenaccessinitiative.org/boai-10-translations/ portuguese-brazilian-translation>. Acesso em: 21 ago. 2015. 
Por fim, seria o desconhecimento sobre as políticas de acesso aberto. É importante notar, entretanto, que a universidade possui uma política para o depósito de pesquisas científicas no repositório da instituição - o RepositóriUM. Tal política resultou, certamente, da identificação de receio e de dúvidas referentes aos direitos autorais por parte dos pesquisadores, o que representava um grande inibidor de depósitos. A reação foi a criação do Serviço de Ajuda e Esclarecimento sobre Políticas de Copyright e Auto-Arquivo para os membros da Universidade, incluído na própria interface do RepositoriUM (RODRIGUES, 2013, p. 35).

Uma das conclusões obtidas do estudo realizado pela própria Universidade de Portugal (Príncipe et al., 2012, p. 8) é a seguinte

Para garantir um elevado nível de adesão e sucesso dessas políticas será necessário facilitar o cumprimento das políticas por parte dos investigadores (criando procedimentos e ferramentas amigáveis e que impliquem o menor trabalho possível), prosseguir com atividades regulares de sensibilização, informação e divulgação e implementar mecanismos de monitorização e alerta para o cumprimento, ou falta dele, das políticas definidas.

Friend (2013, p. 23) acrescenta que uma política de acesso aberto deve deixar claro que num contexto de livre acesso ao conteúdo das pesquisas a decisão dos autores a respeito de continuar ou não utilizando editoras para publicação de suas obras será um questão de custo e de conveniência ao invés de uma questão de necessidade. Sobre essa questão, Suber (2012, p. 87) ensina que políticas bemsucedidas são implantadas através de expectativas, educação, incentivos e assistência, não de coerção. Uma política de acesso aberto que possui o apoio dos próprios membros da Universidade possui maior legitimidade e não precisa ser imposta, já que haveria o apoio natural por parte dos autores, que são os interessados diretos. No caso dos Estados Unidos, as faculdades aderem ao acesso aberto por iniciativa própria, com o apoio de seus membros. Essa política é votada e aprovada por unanimidade. Assim, a universidade já possui uma autorização tácita para que as pesquisas científicas produzidas sejam depositadas em seu repositório (SUBER, 2012, p. 79-80).

Deve sempre ficar claro aos pesquisadores que a propriedade intelectual da obra é de seu autor, mesmo que publicada ou depositada em veículos de acesso 
aberto. Assim, ao tomar conhecimento que o destino de sua pesquisa ficará a cargo dele próprio, o autor apresenta menos resistência em buscar o acesso aberto para difundir sua produção científica. Tomaél e Silva (2007, p. 07) explicam que é de responsabilidade dos autores a submissão de suas obras e o grau de restrição ao acesso de seu conteúdo, de forma a garantir sua propriedade sobre o conteúdo produzido.

As políticas das universidades podem se apresentar como de incentivo ou como mandatória (mandate) ${ }^{14}$ (SUBER, 2012, p. 78). As primeiras podem ser adotadas em publicações tanto na via verde, quanto na via dourada, visto que se referem a esclarecimentos, sugestões e convencimento para que os autores depositem suas obras em repositórios institucionais ou as publiquem em periódico de acesso aberto. As mandatórias, no entanto, como políticas mais incisivas - isto é, que determinam a ação do autor na publicação ou depósito de obras - não podem ocorrer na via dourada, já que envolve o relacionamento do autor com editoras alheias à instituição.

Com o intuito de registrar as políticas institucionais que promovem o acesso aberto à literatura científica a rede EPrints.org, desenvolvida pela Universidade de Southampton no Reino Unido, financiada pelo Joint Information Systems Committee (JISC) criou um diretório internacional de pesquisa de registros de políticas de Acesso Aberto chamado Registry of Open Access Repository Mandates and Policies (ROARMAP). A finalidade é a disponibilização de um registro internacional pesquisável com o objetivo de mapear a quantidade de políticas mandatórias de acesso aberto adotadas por universidades, instituições de pesquisa e financiadores

${ }^{14}$ O próprio Suber (2012, p. 88), que chama essa política mais impositiva de "Open Access Mandate", procura deixar claro que possui ressalvas com relação ao uso da palavra "mandate", que daria uma impressão de que a instituição obrigaria o autor a disponibilizar sua obra em meios de acesso aberto. Essa não seria a ideia por trás dessa política, visto que não é possível obrigar o autor a tomar qualquer providência com relação ao seu trabalho. Na verdade, o objetivo de políticas como essa seria o de tornar o acesso aberto mais atrativo aos autores, mas em momento algum imporia qualquer tipo de comportamento indesejado aos acadêmicos. 
de pesquisa que exijam ou solicitem aos seus pesquisadores a disponibilização de seus trabalhos em repositório de acesso aberto.

A figura 8 ilustra a quantidade de políticas registradas no ROARMAP por ano, por trimestre e por tipo de instituição. Ademais, é possível analisar o aumento da quantidade de políticas registradas desde 2005.

Figura 8 - Quantidade de políticas registradas no ROARMAP

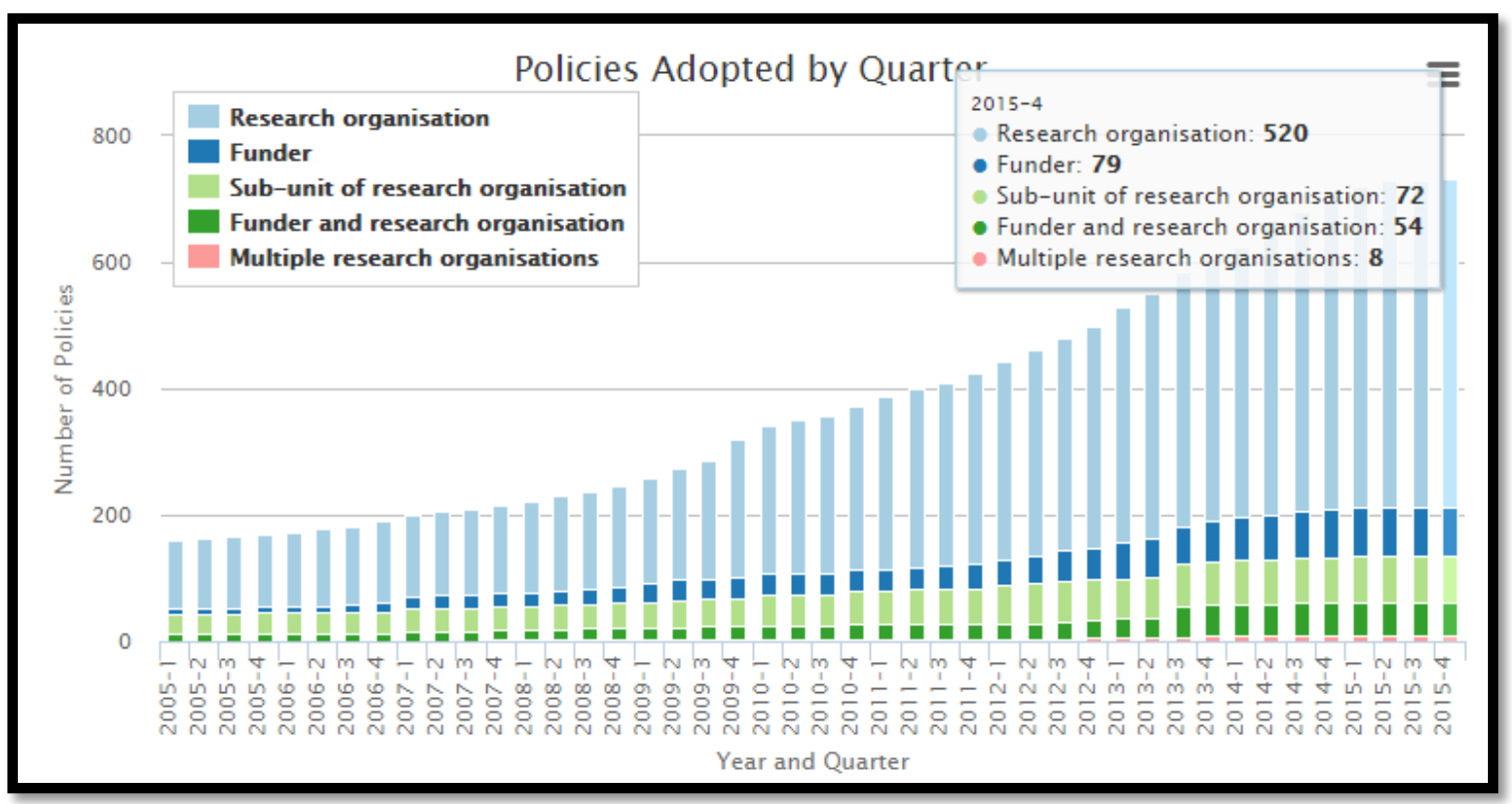

Fonte: ROARMAP (2015). Disponível em: <http://roarmap.eprints.org/>. Acesso em: 20 ago. 2015.

Em março de 2015, em estudo realizado ${ }^{15}$ pela Open Access Policy Alignment Strategies for European Union Research (PASTEUR4OA) ${ }^{16}$ contabilizaram-se 663 políticas registradas no ROARMAP. Destas, 60\% são políticas de Acesso Aberto europeias. Aproximadamente dois terços são políticas

${ }^{15}$ Disponível em: <http://pasteur4oa.eu/sites/pasteur4oa/ files/deliverables/ PASTEUR4OA\% 20Work\% 20Package\%203\%20Report\%20final\%2010\%20March\%202015.pdf>.Acesso em: 20 ago. 2015.

${ }^{16}$ PASTEUR4OA é um projeto que visa a apoiar a recomendação da Comissão Europeia aos Estados-Membros de Julho de $\mathbf{2 0 1 2}$ a fim de desenvolver e implementar políticas que garantam o Acesso Aberto a todas as pesquisas com financiamento público na União Europeia. Além disso, a PASTEUR4OA auxilia e reforça as estratégias de acesso aberto e políticas a nível nacional com o intuito de facilitar a sua coordenação entre todos os Estados-Membros. Disponível em:< http://www.pasteur4oa.eu/>. Acesso em: 25 ago. 2015. 
institucionais e cerca de 10\% são políticas de instituições financiadoras de pesquisa. Mais de metade são mandatórias, requerendo alguma ação para além de uma simples recomendação. Importante observar que mais de $60 \%$ dessas políticas mandatórias são européias, conforme ilustra a figura 9.

Embora o ROARMAP demonstre o sucesso da iniciativa do acesso aberto por meio do crescimento do registro de políticas, os números na América do Sul ainda são tímidos se comparados à quantidade de universidades na região. No caso do Brasil, um dos motivos, além dos que já mencionados anteriormente, pode ser o impasse da legislação brasileira de direitos autorais e sua relação com os atos administrativos que regulam as políticas de informação institucional.

Figura 9 - Número de políticas de acesso aberto no mundo (mandatória e nãomandatória)

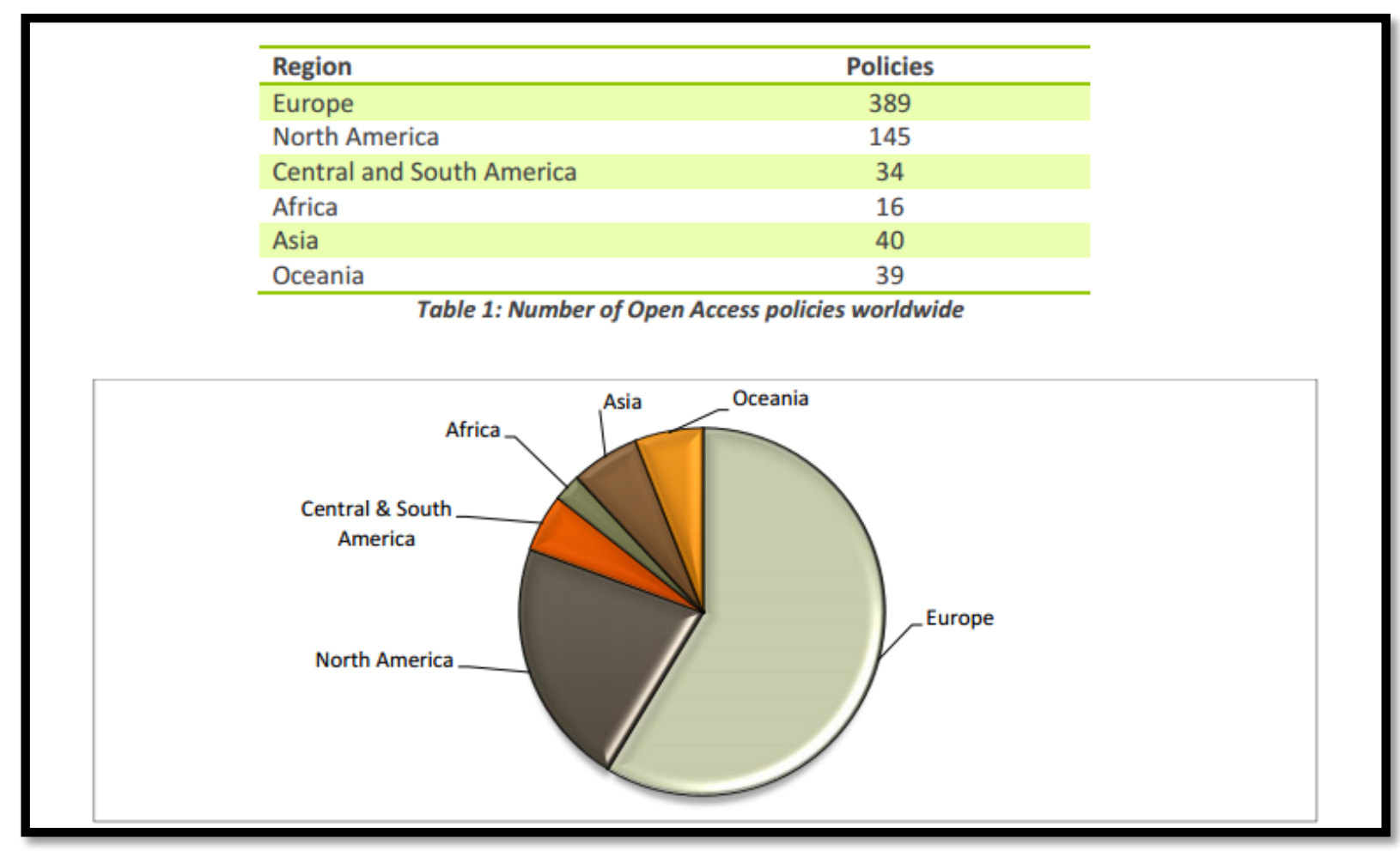

Fonte: PASTEUR4OA (2015, p. 17). Disponível em: <http://pasteur4oa.eu/sites/pasteur4oa/ files/deliverables/PASTEUR4OA\%20Work\%20Package\%203\%20Report\%20final\%2 010\%20March\%202015.pdf >. Acesso em: 10 ago. 2015. 
A seção 2.5.4 trata das políticas institucionais à luz do direito administrativo brasileiro. O propósito é esclarecer a relação entre política institucional publicada por meio de um ato administrativo e o ordenamento jurídico pátrio.

\subsubsection{Políticas institucionais à luz do direito administrativo: 0 ato administrativo}

$\mathrm{O}$ ato administrativo revela-se o mais clássico dos temas do Direito Administrativo. Para muitos autores, o ato administrativo foi um dos elementos de caracterização do Estado de Direito, se comparado ao Estado Absoluto ou ao Estado de Polícia, no tocante à maneira de atuação das autoridades públicas. (MEDAUAR, 2012, p. 12). A expressão ato administrativo surge, pela primeira vez, no conceito introduzido por Merlin (1812 apud Silva et al, 2006, p. 277) como " uma decisão de autoridade administrativa ou uma ação, um fato da administração que tenha relação com suas funções". Em sentindo amplo, Mello (2004, p. 352) propõe que $o$ ato administrativo é a

\footnotetext{
declaração do Estado (ou de quem Ihe faça as vezes - como, por exemplo um concessionário de serviço público), no exercício de prerrogativas públicas, manifestada durante providências jurídicas complementares da lei à título de lhe dar cumprimento, e sujeitas controle de legitimidade por órgão jurisdicional.
}

Por sua vez, Di Pietro (2010, p.196) define o ato administrativo como a "declaração do Estado ou de quem o represente, que produz efeitos jurídicos imediatos, com a observância da lei, sob regime jurídico público e sujeita a controle pelo Poder Judiciário". (Grifo nosso) O conceito de ato administrativo trazido por Di Pietro menciona o Princípio da Legalidade, o qual advém de concepções estrangeiras e, portanto, faz necessário destacar a concepção adotada pelo ordenamento jurídico pátrio para uma posterior análise.

Hoje, no direito público brasileiro, existem duas correntes sobre o tema. A primeira defende a vigência da concepção clássica, com algumas considerações, e afirma que a Administração deve limitar-se a executar a lei, mas, nos casos de supremacia especial, admite-se a possibilidade de regulamentos expressamente ou implicitamente autorizados. A segunda corrente defende a admissibilidade irrestrita 
dos regulamentos autorizados. Essa última é a concepção alemã, e é corrente minoritária na doutrina brasileira pelos motivos expostos a seguir.

A Constituição de 1988 adota, no art. 50, II, o princípio da legalidade e restringe, no art. 84, IV, os decretos e regulamentos à fiel execução das leis. Martins (2008, p. 83) explica que os defensores da concepção alemã argumentam que ao se exigir expressa autorização legislativa para que a disciplina se dê por regulamento, afastada estaria qualquer ofensa aos dispositivos mencionados. No entanto, o autor afirma, ainda, que os defensores dessa corrente esqueceram-se da previsão constitucional da lei delegada prevista no art. 68. Ou seja,

a autorização legislativa para que a matéria seja disciplinada em regulamento viola frontalmente a exigência de que o exercício de ponderações em abstrato pelo Executivo - ressalvadas as medidas provisórias (restritas aos casos de relevância e urgência) - se dê pela lei delegada.

Com isso, o autor conclui que é inadmissível qualquer aproximação com a doutrina francesa que prevê os regulamentos autônomos e autorizados no art. 37 de sua Constituição, pois no Brasil esses regulamentos são vedados pelo sistema jurídico. (MARTINS, 2008, p. 83).

Mas mesmo dentre os defensores da doutrina clássica prevalece, hoje, a admissão de exceção ao impedimento dos regulamentos autorizados. Quando o administrado se insere numa relação específica com a Administração, diversa da que ela tem com a generalidade das pessoas. A doutrina majoritária sustenta que nessas hipóteses excepcionais é possível a instituição de direitos e obrigações, num plano abstrato, pelos regulamentos. Martins (2008, p. 84) expõe o exemplo da cobrança de multas em bibliotecas públicas

um exemplo escolar é o das bibliotecas públicas: a doutrina admite a imposição, por portaria, decreto ou outro veículo introdutor de norma abstrata, de multa pela não-devolução, no prazo fixado, do livro retirado pelo usuário. Trata-se, no caso, indiscutivelmente, de obrigação imposta por esse veículo normativo, e não pela lei. Observe-se que a multa é admitida ainda que na lei não haja "expressa" autorização para a sua instituição. 
Nesse exemplo o autor afirma que há um consenso sobre a necessidade de sancionar o usuário de uma biblioteca que não devolve o livro. Na ausência de lei que prevê essa sanção, surge uma "lacuna normativa inadmissível". E, como a sanção não pode ser fixada para cada ato de empréstimo e por ser uma condição indispensável para a manutenção da biblioteca, a doutrina, neste caso, admite a fixação da sanção por meio de ato administrativo regulamentado pelo poder Executivo.

Apesar de aceita essa solução por parte da doutrina, aqueles que discordam afirmam que regulamentos expressa e implicitamente autorizados são inconstitucionais uma vez que o sistema prevê a edição de medida provisória para os casos de "lacuna normativa inadmissível". E, se ainda assim, o legislador se omitir, o Poder Judiciário pode se valer da "troca de sujeito" para que outro agente (estado ou município) discipline a matéria por meio de edição de medidas provisórias com base no princípio da simetria. Entretanto, Martins (2008, p. 85) conclui ao dizer que por força do Princípio da Necessidade, "o sistema jurídico pode até acolher provisoriamente a solução fixada pelo Executivo no regulamento, mas este, à luz da Constituição de 1988, será sempre uma anomalia de flagrante inconstitucionalidade."

Os atos administrativos gerais e abstratos equiparam-se materialmente as leis de acordo com Almeida (2012). Porém, "formalmente são atos de inferior hierarquia em relação às leis, devendo, portanto, fundamentar sua validade no que dispõem os atos que formalmente sejam leis". O autor cita, ainda, a Declaração de Direitos de Massashussets, de 1780, art. 30 ao defender que o Estado de Direito trata-se do "governo de leis, não de homens". Assim sendo, Almeida (2012) conclui que no contexto da legalidade própria do Estado de Direito, os atos administrativos normativos "atendem ao princípio democrático, ao subordinarem-se às leis que formalmente derivam da vontade dos representantes do povo, e promovem, no plano infralegal, a existência de mais um escalão de tratamento normativo geral e abstrato". Portanto, os atos administrativos normativos materialmente equiparam-se às leis, mas subordinam-se às leis formais, pois tem sua validade fundamentada nas leis. 
Outro aspecto que vale a pena ressaltar diz respeito à função administrativa da Administração Pública essa discussão será vinculada mais adiante à discussão do estado da arte das políticas de direito autoral das universidades federais. A função administrativa

consiste na apuração da medida constitucional da exigência de cumprimento de determinados fins, tendo em vista as circunstâncias do acaso e a atividade legislativa até então exercida; bem como a fixação de acordo com a medida apurada, dos meios necessários para realização desses fins". (ALMEIDA, 2012)

De acordo com o princípio da Separação dos Poderes, é vedado à Administração Pública, salvo no exercício da função legislativa (que se dá pela edição de medidas provisória e de leis delegadas), fixar o peso dos princípios em abstrato. Ou seja, a Administração está vinculada à observância da ponderação efetuada pelo legislador. A Administração, na ponderação que efetuar, deverá atentar para a diferença de peso previamente fixada pelo constituinte (ponderação constitucional) e pelo legislador (ponderação legal).

A discussão acerca do ato administrativo se mostrou necessária em razão do fato de todas as dezenove políticas de repositórios institucionais de universidades federais brasileiras registradas no Registry of Open Access Repository (ROAR) terem sido instituídas por meio de Resolução ou Portaria. Para Di Pietro (2010, p. 236) "resolução e portaria são formas de que se revestem os atos, gerais ou individuais, emanados de autoridades outras que não o Chefe do Executivo".

De fato, as políticas de Rl's tem como um de seus objetivos exigir o acesso além de garantir o depósito da pesquisa patrocinada pelo Estado. Estão, portanto, condicionadas à Legislação de Direitos Autorais. Essa discussão cresce à medida que Universidades se utilizam de atos normativos - instrumento autorizado pelo Direito Administrativo - para regulamentar as questões de direitos autorais pertinentes à disponibilização da produção científica gerada com patrocínio público. Isso ocorre porque os atos administrativos não podem contrariar as leis por se subordinarem à Constituição e à legislação infraconstitucional. 
A Lei de Direitos Autorais determina em seu art. 28 que "cabe ao autor o direito exclusivo de utilizar, fruir e dispor da obra literária, artística ou científica." Com isso, a norma brasileira acaba por tornar tímidas as políticas de acesso aberto adotadas pelas Universidades.

Ortellado (2008, p. 193) enfatiza a necessidade de as instituições brasileiras adotarem políticas de arquivamento compulsório, em especial os principais financiadores (CAPES e CNPq), as universidades ou mesmo o governo, por meio da aprovação do Projeto de Lei n. 1120/2007 (hoje, n. 387/2011). O autor defende, ainda, que "uma proposta como essa, se implementada, resolveria imediatamente o problema do acesso à informação científica na sua dimensão mundial".

\subsubsection{Projeto de Lei 387/2011: a reforma que não acontece}

No Senado Federal está em trâmite o Projeto de Lei $n^{\circ} 387 / 2011$, de autoria do então Senador Rodrigo Rollemberg, que dispõe sobre o processo de registro e disseminação da produção técnico-científica pelas instituições de educação superior, bem como pelas unidades de pesquisa no Brasil, além de outras providências. $O$ referido Projeto de Lei já foi apresentado pelo mesmo parlamentar no ano de 2007, oportunidade em que ocupava a função de Deputado Federal, e, sob o número PL 1.120/2007. O projeto foi arquivado pela Mesa da Câmara dos Deputados por ultrapassar a legislatura em que fora apresentado, sem aprovação daquela casa legislativa. Dessa forma, na legislatura seguinte o parlamentar, já na função de Senador, apresentou novamente a proposta para nova tramitação legislativa.

O projeto original é composto de três artigos. O artigo $1^{\circ}$, dividido em onze parágrafos, contém a essência do projeto, sendo que seu caput prevê a obrigação de que as instituições públicas de ensino superior devem criar repositórios institucionais eletrônicos de acesso aberto. Nestes, deverá ser depositada toda a produção científica dos cursos de pós-graduação stricto sensu, além da produção científica resultante das pesquisas realizadas com o financiamento governamental, seja federal, estadual, distrital ou municipal. 
Os parágrafos do artigo $1^{\circ}$ estabelecem o funcionamento dos referidos repositórios, bem como responsabilidades institucionais para sua disponibilização ao público. Tais repositórios deverão, ainda, ser compatíveis com padrões internacionais de interoperabilidade, visando eventual integração a repositórios estrangeiros, cuja responsabilidade de gestão será delegada a órgão competente a ser designado por ato da União. O texto da proposta prevê, também, o depósito imediato da produção científica, considerando o marco temporal para tal obrigação o momento de sua aprovação de publicação por revista científica, ou o momento de aprovação pela respectiva instituição. Está previsto que os metadados devem ser depositados em caso de impedimento de depósito total de produção científica que eventualmente esteja amparada por contrato propriedade intelectual, invenção ou modelos patenteáveis, limitação esta que durará apenas enquanto a restrição estiver em vigor. Além disso, as instituições de pesquisa e entidades financiadoras ficam obrigadas a considerar, para análise e apreciação da produção científica, a quantidade de trabalhos publicados em periódicos com revisão por pares (peer review) que também foram depositados nos repositórios institucionais.

Já o artigo $2^{\circ}$ determina a organização de um colegiado de alto nível, representado pela comunidade acadêmica que participa processo de produção do conhecimento científico, para a proposição de uma política nacional de acesso aberto à informação científica. Por fim, o artigo $3^{\circ}$ determina um prazo de 90 (noventa) após sua publicação para que a referida Lei entre em vigor.

O Projeto de Lei no $387 / 2011$ foi distribuído à Comissão de Ciência, Tecnologia, Inovação, Comunicação e Informática (CCT) e à Comissão de Educação, Cultura e Esporte (CE), ambas do Senado Federal, cabendo a esta última a decisão terminativa. O Senador Cristóvam Buarque foi designado relator na CCT, manifestando-se por sua aprovação com as emendas apresentadas. No dia 28 de maio de 2013, a Comissão aprovou o relatório.

Dentre as emendas apresentadas e aprovadas na CCT, está uma redação nova ao artigo $1^{\circ}$ incluindo instituições de ensino ou de pesquisa privadas que venham a receber financiamento público, está também uma alteração no artigo $2^{\circ}$, 
que a partir de então inclui conceitos para "apoio financeiro", "Instituição Científica e Tecnológica (ICT)", "pesquisador" e "produção técnico-científica". A emenda que apresenta alteração mais substancial é a quarta, que inclui mais três artigos no PL. O novo art. $3^{\text {}}$ define princípios e objetivos para orientar o desenvolvimento e a operacionalização dos repositórios institucionais. Já o novo artigo $4^{\underline{0}}$ prevê que a produção de conhecimento financiada pela União, Estados, Distrito Federal e Municípios deverá necessariamente ser depositada em repositório institucional eletrônico de acesso aberto. Além disso, em seus parágrafos, normatiza a criação, operação e funcionamento de tais repositórios pelas ICTs. O artigo $5^{0}$ criado discorre sobre a integração dos repositórios institucionais das ICTs e sobre a disposição por órgão federal quanto aos critérios de interoperabilidade e quanto à orientação e à assistência técnica prestada aos ICTs para a criação de seus repositórios institucionais. A última emenda apresentada altera de 90 (noventa) para 180 (cento e oitenta) dias o prazo para a entrada em vigor da Lei.

Encaminhado à Comissão de Constituição e Justiça (CCJ), e designado o Senador Álvaro Dias como relator da proposta na CCJ, no dia 14 de novembro de 2013 foi apresentado o relatório opinando pela rejeição da matéria por ser, em tese, inconstitucional e injurídico. Os argumentos do relator para considerar a proposta como eivada de injuridicidade e inconstitucionalidade dizem respeito à nãoobservação da autonomia das universidades e das instituições de pesquisa para a definição de seus planos, programas e projetos de pesquisa científica, consoante a Lei de Diretrizes e Bases da Educação - LBD (Lei no 9.394/96). Referem-se, ainda, à violação da competência privativa do Presidente da República de organizar o funcionamento dos órgãos e instituições da administração pública e de iniciar o processo legislativo para sua própria organização e funcionamento quando resultarem aumento de despesa ou a criação/extinção de órgãos públicos (art. 61 e 84, Constituição Federal). Além disso, entendeu o relator que a regulamentação da proposta para a democratização da produção científica, objeto do referido PL, não deveria ser concretizada em lei autônoma, tendo em vista o que dispõem a Lei $n^{\circ}$ 10.793/04 e a Lei no 12.527/11, que, em tese, já regulamentam a matéria ora tratada. Assim, eventual proposta de alteração do que já está previsto nos normativos mencionados deveria ser realizada por projeto de lei que altera direta e 
nominalmente tais dispositivos legais. O PL aguarda votação pela $\mathrm{CCJ}$ desde o dia 03 de abril de 2014 até a data de conclusão deste trabalho. 


\section{METODOLOGIA}

O presente estudo fundamenta-se nas noções essenciais às discussões sobre o direito autoral no contexto do acesso aberto. Para isso, foram delineados procedimentos metodológicos que têm por base a abordagem qualitativa. Adota, ainda, as orientações de Kvale (1996) para análise dos textos tanto da literatura quando das entrevistas realizadas, assim como os dados obtidos dos sites dos repositórios. Embora o autor defina um conjunto de procedimentos relacionados com a análise de textos de entrevistas, entendeu-se que as mesmas orientações metodológicas são úteis à análise de textos da literatura e dos sites.

O presente capítulo está dividido em duas seções. A primeira constitui o referencial teórico adotado para o estudo, a partir da análise da literatura. São abordados os conceitos que constituem a base teórica para o tema estudado e que norteiam a condução do estudo. A segunda apresenta o plano ou desenho da pesquisa propriamente dita, descrevendo os procedimentos metodológicos.

\subsection{Referencial teórico}

São três as questões relevantes discutidas sobre o tema deste estudo. Primeiro, a comunicação científica, discutida sucintamente como o contexto mais amplo em que se insere a discussão, incluindo o acesso aberto. Segundo, as legislações nacionais e internacionais sobre direitos do autor relacionadas ao acesso aberto à informação, como panorama mundial do estado da arte das políticas de direito autoral para o acesso aberto à literatura científica. Por fim, o direito autoral no contexto do acesso aberto, bem como a teoria da ACF adotada para o estudo do movimento do acesso aberto.

\subsubsection{Conceitos da pesquisa}

Considerando o problema estudado no presente trabalho, três conceitos são essenciais à abordagem teórica adotada, nomeadamente, repositório institucional, política de informação de acesso aberto, política de direito autoral. São, portanto, estes os conceitos que compõem o referencial teórico do estudo. 


\section{Repositórios Institucionais de acesso aberto}

Repositórios institucionais de acesso aberto neste estudo são definidos como "um conjunto de serviços que a universidade oferece aos membros de sua comunidade para gestão e disseminação de materiais criados pela universidade e membros de sua comunidade" (LYNCH, 2003, p. 226). De acordo com o foco do estudo, o objetivo é pontuar elementos de política de direito autoral para esse tipo de serviço.

\section{Política de informação para repositórios institucionais de acesso aberto}

O presente estudo utiliza os dois conceitos de política trazidos por Suber (2012, p.78) para qualificar políticas de informação para repositórios no contexto do acesso aberto:

- $\quad$ políticas de incentivo, que são meramente esclarecedoras;

- $\quad$ políticas mandatórias, incisivas e que buscam determinar a ação dos autores.

O objetivo, portanto, é analisar, sob essas duas óticas, as políticas brasileiras nas questões institucionais, legais e tecnológicas que se relacionam com os direitos autorais.

\section{Direito autoral}

O conceito de direito autoral adotado nesta pesquisa diz respeito ao direito que se baseia na definição francesa, adotada pelo Brasil. É definido pela teoria unionista que reconhece a "relação criativa entre o autor e o seu direito de utilizá-la economicamente", conforme definido por Souza (2003). É importante ressaltar que a análise, apesar de se valer, principalmente, dos direitos autorais patrimoniais (copyright), considera, também, os direitos morais do autor para definir as orientações e diretrizes da política de direito autoral para repositórios institucionais. 


\section{Relações entre os conceitos da pesquisa}

Os objetivos do presente estudo apontam não somente que resultados devem ser atingidos, mas, principalmente, qual o referencial teórico a ser construído. Nesse sentido, é importante descrever como os conceitos da pesquisa estão relacionados. O que a análise da literatura apontou permite propor que, para a elaboração de políticas de direito autoral para repositórios institucionais de acesso aberto, é necessário levar em conta duas questões. A primeira diz respeito às políticas públicas nacionais, incluindo as regulamentações sobre direito autoral. A segunda relaciona-se aos aspectos da comunicação científica no contexto do acesso aberto, particularmente as questões relacionadas com a via verde.

\subsection{Plano da pesquisa}

\subsubsection{Abordagem, método da pesquisa e instrumentos de coleta de dados}

Considerando-se que o assunto aqui tratado, apesar de explorado, constitui uma lacuna na questão dos direitos autorais, especialmente na Ciência da Informação, e no Brasil, decidiu-se por um desenho de pesquisa analítica descritiva, com elementos de pesquisa teórica em um primeiro momento, e de pesquisa aplicada em um segundo. O estudo se baseia, inicialmente, na análise da literatura identificada como recente e relevante sobre os temas necessários à abordagem apresentada. Em seguida, utiliza, por meio de análise documental, as informações constantes das políticas dos repositórios de universidades brasileiras registradas no ROARMAP. Este, portanto serviu como base amostral para esta fase do estudo, Posteriormente, identifica a percepção e as experiências de atores do sistema de comunicação científica, por meio de entrevistas semi-estruturadas em profundidade com gestores de repositórios sobre a questão do direito autoral no contexto do acesso aberto. Os dados obtidos visaram à identificação de elementos estruturantes para elaboração de políticas de direito autoral para repositórios institucionais de acesso aberto.

Para a análise da literatura o estudo adotou o método de pesquisa bibliográfica. Para a análise das políticas dos repositórios institucionais das 
universidades brasileiras, a análise documental. Para as entrevistas com especialistas, o estudo de múltiplos casos, envolvendo uma univerisdade brasileira, uma americana e uma portuguesa, selecionadas intencionalmente, por constituírem exemplos de iniciativas bem sucedidas nesses países.

Desse modo, a investigação propriamente dita envolveu seis etapas. A primeira compreendeu a identificação de autores relevantes na literatura recente sobre comunicação científica e sobre direito autoral e políticas públicas, embora a análise tenha envolvido questões históricas do Direito. A segunda etapa consistiu da leitura, interpretação e análise comparativa do conteúdo dessa literatura. A terceira envolveu identificação, após levantamento no ROARMAP, das políticas de acesso aberto adotadas pelas universidades brasileiras. A quarta etapa consistiu na identificação das percepções e experiências de gestores de repositórios e de um especialista, a respeito do direito autoral no âmbito de repositórios institucionais de acesso aberto. A quinta etapa compreende a condensação, a categorização e a interpretação dos textos resultantes das etapas anteriores. Finalmente, a sexta etapa compreendeu a identificação de elementos necessários e indispensáveis à elaboração de política de direito autoral para repositórios institucionais de universidades brasileiras, no contexto do acesso aberto.

Sobre as entrevistas, vale a pena destacar o que observa Creswell (2010, p. 213,), a respeito da vantagem em permitir que o ambiente em que se realiza a entrevista face-a-face poder ser observado. Isso, por certo, contribui para o aprofundamento do entendimento das questões abordadas e do contexto. Todas as entrevistas foram gravadas em áudio e transcritas para a análise do conteúdo.

\subsubsection{Universo e amostragem}

O tamanho do corpus da pesquisa se restringiu ao conteúdo das entrevistas realizadas nos três casos estudados, ao conteúdo das políticas dos repositórios das universidades brasileiras identificadas no ROARMAP e ao conteúdo da literatura relevante (não exaustiva) selecionada para discussão teórica do tema. Procurou-se, desse modo, evitar a criação de "porões de dados", ou seja, materiais coletados, mas nunca analisados (BAUER; GASKELL, 2002). 
O universo para cumprir o primeiro objetivo específico, que focou na descrição das questões que fundamentam a discussão sobre o direito autoral no contexto do acesso aberto, foi pautado pela literatura científica e legal, recente e relevante sobre o tema. Para o segundo objetivo, cujo escopo era identificar políticas de informação para repositórios digitais de acesso aberto, o universo compôs-se de três estudos de caso e de todas as políticas institucionais de acesso aberto das universidades brasileiras registradas no ROARMAP (11 políticas). No caso das entrevistas, os casos selecionados para estudo levaram em conta a relevância das instituições envolvidas nas iniciativas de acesso aberto. No caso da universidade portuguesa, sua importância é notória entre os profissionais da área, em nível mundial, pelas contribuições e avanços que tem apresentado ao longo dos últimos 10 anos. A universidade dos Estados Unidos apresenta uma política que, embora compulsória, mostra-se também democrática e legítima, o que chamou a atenção, pois pareceu confuso na literatura. Já a universidade brasileira é pioneira nessas questões no país, tendo colaborado com iniciativas em várias outras universidades do brasileiras. Para o terceiro objetivo, que visou a identificar elementos necessários à elaboração de política de direito autoral para repositórios digitais de acesso aberto, utilizou-se a reunião do universo e da amostra do primeiro e do segundo objetivos.

\subsubsection{Técnicas de análise dos dados}

Para todos os objetivos foram desenhada as mesmas técnicas de análise de dados, quais sejam, a condensação, a categorização e a interpretação. Essa técnica é pautada pela "categorização de significado, condensação de significado, estruturação de sentido por meio de narrativas, interpretação de significado, e métodos ad hoc para a geração de significado" (KVALE, 1996, p.187, tradução nossa). As orientações do autor foram adotadas para todo o corpus da pesquisa, por este se constituir de textos, tal como ocorre nas transcrições de entrevistas.

Kvale (1996, p.188) afirma que a condensação de significado envolve a redução de longas sentenças em formulações sucintas em que a frase é reduzida a palavras com maiores significados. Já a categorização de significado implica em codificar a entrevista ou os documentos em categorias, permitindo transformar textos 
extensos em tabelas ou figuras, o que facilita a análise. A interpretação de significado vai além de uma estruturação do significado, visto que um mesmo conteúdo pode ser analisado de diversas formas, de acordo com o ponto de vista de quem faz a análise. Com isso, o autor revela a "hermenêutica da suspeita", ou seja, é necessário estruturar os dados para que o interpretador veja além do que foi diretamente expresso no texto.

Para ilustrar o plano da pesquisa, o quadro 1 resume seus elementos essenciais, nomeadamente, objetivos específicos, fontes de dados, técnicas de pesquisa, instrumentos de coleta de dados, técnicas de análise de dados e universo/amostra. O objetivo do quadro é mostrar as questões metodológicas da pesquisa, facilitando seu entendimento. 
Quadro 1 - Resumo da metodologia da pesquisa

\begin{tabular}{|c|c|c|c|c|c|}
\hline Objetivos especificos & Fonte & Método & $\begin{array}{l}\text { Instrumento de coleta } \\
\text { de dados }\end{array}$ & $\begin{array}{c}\text { Técnica de análise de } \\
\text { dados }\end{array}$ & $\begin{array}{l}\text { Universo/ } \\
\text { Amostra }\end{array}$ \\
\hline $\begin{array}{l}\text { 1. Descrever questôes que } \\
\text { fundamentam a } \\
\text { discussão sobre o direito } \\
\text { autoral no contexto do } \\
\text { acesso aberto à literatura } \\
\text { científica; }\end{array}$ & $\begin{array}{l}\text { Textos de publicações } \\
\text { científicas e legais }\end{array}$ & $\begin{array}{l}\text { Pesquisa } \\
\text { bibliográfica e } \\
\text { documental }\end{array}$ & $\begin{array}{l}\text { Buscas por palavras- } \\
\text { chave em bases de } \\
\text { dados digitais e em } \\
\text { catálogos de } \\
\text { bibliotecas }\end{array}$ & $\begin{array}{l}\text { Condensação, } \\
\text { categorização e } \\
\text { interpretação, de } \\
\text { acordo com Kvale } \\
\text { (1996). }\end{array}$ & $\begin{array}{l}\text { Literatura relevante } \\
\text { e recente; } \\
\text { Legislação nacional } \\
\text { e internacional }\end{array}$ \\
\hline $\begin{array}{l}\text { 2. Analisar elementos de } \\
\text { políticas de informação, } \\
\text { com relação aos direitos } \\
\text { autorais, para repositórios } \\
\text { digitais de acesso aberto; }\end{array}$ & $\begin{array}{l}\text { Textos de publicações } \\
\text { legais (relatórios, guias e } \\
\text { documentos oficiais) } \\
\text { Textos de políticas } \\
\text { institucionais de informação } \\
\text { registradas no ROAR; } \\
\text { Gestores de repositórios } \\
\text { institucionais de } \\
\text { universidades estrangeiras } \\
\text { e brasileiras. }\end{array}$ & $\begin{array}{l}\text { Pesquisa } \\
\text { documental; } \\
\text { Estudo de múltiplos } \\
\text { casos. }\end{array}$ & $\begin{array}{l}\text { Buscas por palavras- } \\
\text { chave em bases de } \\
\text { dados digitais e em } \\
\text { catálogos de } \\
\text { bibliotecas } \\
\text { Análise do conteúdo } \\
\text { de sites de } \\
\text { repositórios; } \\
\text { Entrevistas } \\
\text { semiestruturadas e em } \\
\text { profundidade, face-a- } \\
\text { face, nos locais de } \\
\text { trabalho, com base em } \\
\text { roteiro }\end{array}$ & $\begin{array}{l}\text { Condensação, } \\
\text { categorização e } \\
\text { interpretaçẫo, de } \\
\text { acordo com Kvale, } \\
\text { (1996). }\end{array}$ & $\begin{array}{l}\text { Políticas } \\
\text { institucionais de } \\
\text { informação } \\
\text { registradas no } \\
\text { ROAR } \\
\text { Gestores dos } \\
\text { repositórios } \\
\text { institucionais de } \\
\text { universidades no } \\
\text { Brasil; nos Estados } \\
\text { Unidos e em } \\
\text { Portugal. }\end{array}$ \\
\hline $\begin{array}{l}\text { 3. Identificar elementos } \\
\text { necessários à } \\
\text { elaboração de políticas } \\
\text { efetivas de direito autoral } \\
\text { para repositórios digitais } \\
\text { de acesso aberto. }\end{array}$ & $\begin{array}{l}\text { Textos de publicações } \\
\text { científicas e legais; } \\
\text { Políticas institucionais de } \\
\text { informação registradas no } \\
\text { ROAR; Textos das } \\
\text { entrevistas. }\end{array}$ & $\begin{array}{l}\text { Pesquisa } \\
\text { bibliográfica e } \\
\text { documental } \\
\text { Estudo de múltiplos } \\
\text { casos. }\end{array}$ & $\begin{array}{l}\text { Buscas por palavras- } \\
\text { chave em bases de } \\
\text { dados digitais e em } \\
\text { catálogos de } \\
\text { bibliotecas } \\
\text { Entrevistas } \\
\text { semiestruturadas e em } \\
\text { profundidade, face-a- } \\
\text { face, nos locais de } \\
\text { trabalho, com base em } \\
\text { roteiro }\end{array}$ & $\begin{array}{l}\text { Condensação, } \\
\text { categorização e } \\
\text { interpretação, de } \\
\text { acordo com Kvale } \\
\text { (1996). }\end{array}$ & $\begin{array}{l}\text { Literatura e } \\
\text { legislações } \\
\text { nacionais e } \\
\text { internacionais; } \\
\text { Políticas } \\
\text { institucionais de } \\
\text { informação } \\
\text { registradas no } \\
\text { ROAR; Gestores } \\
\text { dos repositórios } \\
\text { institucionais de } \\
\text { universidades no } \\
\text { Brasil; nos Estados } \\
\text { Unidos e em } \\
\text { Portugal. }\end{array}$ \\
\hline
\end{tabular}

Fonte: autora (2015). 


\section{ANÁLISE E DISCUSSÃO DOS RESULTADOS}

\subsection{Introdução}

O objetivo da presente pesquisa é, basicamente, apresentar elementos estruturantes necessários para uma política de informação para repositórios digitais científicos, centrada na questão dos direitos autorais no acesso aberto. Trata-se de pesquisa teórica, no sentido em que se fundamenta, em grande parte, na discussão do que está registrado na literatura especializada e nos sites de repositórios institucionais de 11 universidades brasileiras cujas políticas estão registradas no ROARMAP. Adicionalmente, e para efeito de comparação com os resultados da literatura e das políticas dos repositórios, foram realizadas entrevistas com especialistas no tema da pesquisa.

Consequentemente, este capítulo de análise e discussão está organizado em três seções principais. Na primeira parte, apresentam-se os dados obtidos por meio da análise da literatura. Na segunda parte, são apresentados os resultados obtidos por meio das entrevistas em profundidade (in-depth interview), em que se analisam as políticas mandatórias adotadas ou não por três universidades: uma americana, uma brasileira e uma européia (Portugal), justapostas a conceitos identificados na literatura. $\mathrm{Na}$ terceira parte apresentam-se os resultados obtidos nas políticas institucionais de repositórios de 11 universidades brasileiras, também norteadas por conceitos à luz da literatura. Quando possível ou necessário, são apresentados comentários baseados em teorias ou na experiência da pesquisadora.

\subsection{Questões teóricas e legais}

A análise da literatura, composta tanto de textos teóricos quanto legais, revelou questões essenciais para a fundamentação e conceituação dos elementos necessários ao atendimento dos objetivos propostos para esta pesquisa. É importante notar que o contexto em que são estudadas essas questões é o do ensino superior, no sentido em que as instituições de ensino superior exercem papel fundamental na produção e na disponibilização de conteúdo científico. Neste 
trabalho, portanto, o foco é a informação científica produzida, quase essencialmente, em universidades e com recursos do setor público (governamentais), a despeito da participação (às vezes relevante) do setor privado. Isso porque, particularmente em países mais desenvolvidos, há conscientização, por parte de instituições privadas, sobre a informação científica como bem público e de interesse social. O grande questionamento, aqui, alude ao direito de autor e ao direito à informação

\subsubsection{A comunicação científica no acesso aberto e o direito autoral}

Hurd (2004, p. 14) inovou com a apresentação de um modelo que focou na inclusão digital nas etapas do processo de comunicação científica. O modelo ilustra um ambiente colaborativo e interativo que facilita a troca de dados ainda que por grandes distâncias. Acrescenta, no entanto, inovações introduzidas pelo movimento do acesso aberto, notadamente aquelas relacionadas com o depósito do "manuscrito" (e-print) em diferentes locais digitais. Adicionalmente, a autora chama a atenção para novos papeis exercidos pelos principais atores do processo de comunicação científica. Portanto, percebe-se que diversas questões relacionadas aos repositórios institucionais de acesso aberto levam à apresentação de elementos novos que surgem no contexto da comunicação científica. É o caso do direito autoral, especialmente no que diz respeito a mudanças introduzidas pelo acesso aberto.

De fato, a análise da literatura sobre o tema revela a necessidade de inclusão do direito autoral em etapas do modelo de comunicação científica, conforme ilustrado na figura 10. Uma adaptação do modelo de Hurd, com base nesses resultados, requer a inclusão de três elementos de direitos autorais a serem observados de acordo com a etapa correspondente do processo de comunicação científica no contexto do acesso aberto.

O primeiro relaciona-se com o direito ao ineditismo, que configura a vontade do autor de disseminar sua obra. Está relacionado, portanto, com o depósito do eprint em todo tipo de canal escolhido pelo autor, tais como seu website, o repositório de sua instituição, anais de conferências, dentre outros. 
O segundo elemento (negociação entre autor e editor) trata de dois aspectos. O primeiro diz respeito ao tipo de licença de uso a ser utilizado quando da negociação com o editor (direito patrimonial). O segundo trata do direito nãoexclusivo de reprodução, isto é, o autor tem o direito de decidir conferir ou não exclusividade de reprodução à editora a que submeteu seu artigo (direito patrimonial). Esses direitos permitem ao autor o depósito do seu trabalho em outros meios digitais, como já destacado no modelo de Hurd. È importante notar que os direitos autorais não são transferidos ao editor. São, na verdade, licenciados por meio de licença pública, como, por exemplo, a creative commons ${ }^{17}$. Metaforicamente, seria o caso da propriedade de um imóvel, o qual pode ser vendido (transfere-se a propriedade) ou alugado (concede-se o direito de uso, somente). Finalmente, vale a pena ressaltar a questão da negociação ocorre diferentemente, dependendo da divisão do conhecimento, ou mesmo da disciplina. Em áreas das Ciências Sociais e Humanas e das Artes e Humanidades, em que novos valores foram introduzidos no ethos dessas disciplinas pelo acesso aberto, a negociação introduz mudanças estruturais no próprio processo. Isso porque requer que etapas como depósito em diferentes canais ocorram posteriormente à negociação, o que não parece ser o caso de disciplinas como a Física, por exemplo.

O último elemento de direitos autorais incluído no modelo de comunicação científica de Hurd é o que considera o direito à citação do autor, que o sistema do copyright não previa até a assinatura da Convenção de Berna. Esse é um direito personalíssimo e, portanto, moral, uma vez que o autor não pode abrir mão dele. Esse elemento está justamente na etapa que garante ao autor a citação na literatura impressa e digital (na web). Além de ser um dos mais importantes para o direito de autor é também o que garante que o autor seja reconhecido. Mais que isso, possibilita o estudo de impacto da sua produção científica.

Por fim, os atores apresentados por Hurd, com o intuito de definir seus novos papeis no sistema de comunicação científica, passam a representar, de fato,

\footnotetext{
${ }^{17}$ A literatura demonstrou que a licença mais utilizada e adequada para a manutenção dos direitos autorais patrimoniais com o autor é a Creative Commons.
} 
potenciais coalizões, como será visto no próximo resultado da literatura. Destaca-se, em relação a este aspecto, a importância das coalizões, cujos resultados mais inportantes estão relacionados com duas questões. A primeira é o apoio a autores no momento da negociação com editores (o caso do Sparc, por exemplo). A segunda é o depósito em repositórios institucionais, visto que uma política institucional de acesso aberto bem sucedida resulta do trabalho inicial de coalizões fortes que influenciam as políticas públicas. Estas, por sua vez, dão origem a leis que fundamentam a política institucional.

Em suma, as questões relacionadas ao direito autoral no contexto do acesso aberto introduzem mudanças significativas no processo de comunicação científica. Isso porque requerem novos atores, novas etapas no processo e, dependendo da divisão so conhecimento nova estrutura do próprio processo. 
Figura 10 - Modelo de Comunicação Científica de Hurd e o direito autoral

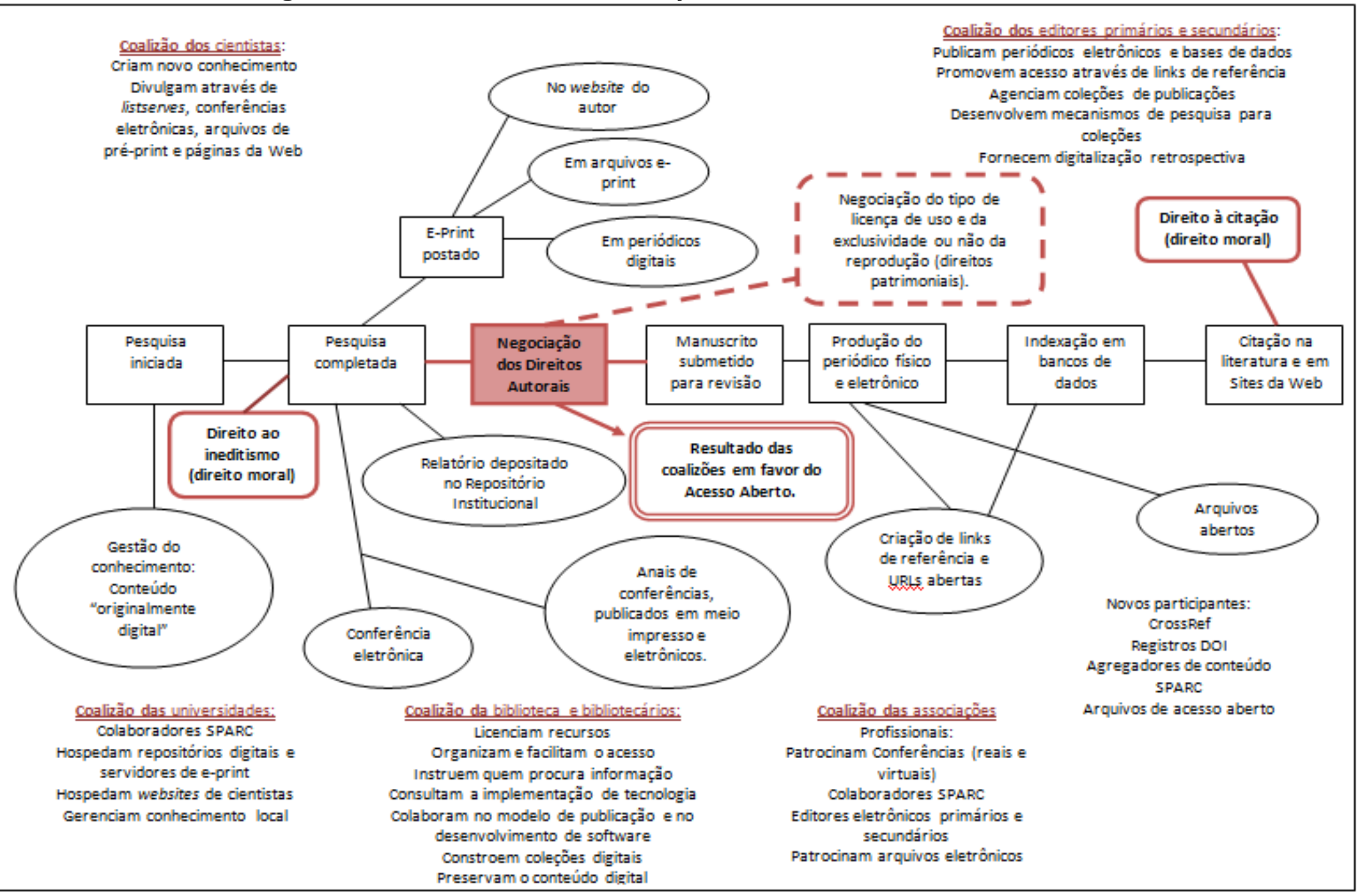

Fonte: Traduzido e adaptado de Hurd (2004). 


\subsubsection{Formação de política pública no contexto do acesso aberto}

A análise da literatura permitiu identificar o modelo de Advocacy Coalition Framework (ACF), proposto por Sabatier; Weible (2005, p.167) como adequado para elaboração ou mudança de uma política pública no contexto do acesso aberto. Isso porque, conforme orienta o autor, deve seguir ao menos quatro premissas.

A primeira compreende o entendimento de que o processo de mudança da política pública e a aprendizagem orientada nele requerem uma perspectiva de tempo de uma década ou mais. A segunda premissa estabelece que a melhor maneira de se pensar a mudança política nesse período de tempo é por meio do foco em um subsistema de política (no caso o movimento do acesso aberto), o qual compreende a interação de atores de diferentes instituições que seguem e influenciam decisões governamentais em uma área política. Como terceira premissa há os subsistemas de política incluídos na dimensão intergovernamental. Ou seja, os atores devem se envolver em todos os níveis do governo, ou, no mínimo, na política institucional. Por fim, a quarta premissa assegura que as políticas públicas (ou programas) podem ser conceituadas da mesma forma que os sistemas de crença, isto é, como um conjunto de prioridades de valores e suposições causais sobre como realizá-los.

A ACF, portanto, trata os subsistemas de política como o conjunto de coalizões imprescindíveis para formação de uma política pública. Ou seja, a ausência de coalizão de advocacy pelo acesso aberto e, consequentemente, de uma política de informação que privilegie o uso justo da obra intelectual atrasa o desenvolvimento científico de uma nação. É importante ressaltar que países que possuem coalizões fortes em prol da Iniciativa do Acesso Aberto, como os Estados Unidos, por exemplo, promovem movimentos capazes de liderar a reforma ou criação de ordenamento jurídico que apóie políticas institucionais de acesso aberto principalmente na questão de direitos autorais. 


\subsubsection{Limitação ao ordenamento jurídico brasileiro e formação de política de direito autoral no contexto do acesso aberto, à luz da teoria da ACF}

No Brasil, as políticas institucionais de informação das universidades têm natureza jurídica de ato administrativo normativo, conforme demonstrado na literatura e nos resultados dos dados levantados a partir da análise das políticas dos repositórios de universidades. A literatura, conforme Almeida, Di Pietro e Martins (2012; 2010 e 2008) afirma que os atos administrativos se subordinam à lei, que, por sua vez, se submetem à Constituição. Segundo Kelsen (1962, p. 255), um sistema jurídico "não é um complexo de normas em vigor, umas junto às outras, senão uma pirâmide ou hierarquia de normas que são superpostas ou subordinadas umas às outras, superiores ou inferiores".

Portanto, a literatura demonstra que os atos administrativos normativos devem atender ao princípio democrático, ao subordinarem-se às leis que formalmente derivam da vontade dos representantes do povo, e promovem, no plano infralegal, a existência do ato normativo geral e abstrato. A figura 11 ilustra o processo de elaboração de uma política institucional de acesso aberto. O processo está dividido em três níveis, nomeadamente, etapas do processo, atores e papéis de atuação dos atores. As etapas são a política pública, a lei, a minuta do ato administrativo e o ato administrativo propriamente dito. Os atores dividem-se nas coalizões de advocacy, nos representantes do povo (corpo legislativo), no gestor do repositório institucional e no reitor (gestor da instituição de ensino ou pesquisa). Os papeis referem-se às atuações de cada ator nas etapas do processo e estão, resumidamente, distribuídos nas ações de influenciar, votar, redigir e publicar.

O processo se inicia na formação de uma política pública em prol do acesso aberto à literatura científica. Essa etapa tem como autor as coalizões, que, por sua vez, exercem o papel de responsáveis por influenciar, por meio da advocacy, a adoção de programas de governo em favor do Acesso Aberto à literatura científica. Em seguida, ocorre a votação do Projeto de Lei por representantes do povo influenciados pelo subsistema de política formado por coalizões de acesso aberto, que cria um cenário favorável à Iniciativa, na medida em que revoga ou reforma a 
atual Legislação de Direitos Autorais. Com o ordenamento jurídico vantajoso para o desenvolvimento do acesso aberto e favorável para o uso justo da obra intelectual, o gestor do repositório redige a minuta da política de informação institucional para repositório institucional de acesso aberto à literatura científica. Finalmente, a política é publicada pelo reitor (gestor da instituição de ensino ou pesquisa) por meio de um ato administrativo (portaria ou resolução) que respeita à lei, sem o risco de ser declarada como flagrante de inconstitucionalidade. A formalização da Iniciativa do Acesso Aberto por meio da política passa a oferecer segurança jurídica aos atores envolvidos diretamente (autor, gestor do repositório e usuário) e fortalece as coalizões dentro da instituição.

A ilustração do processo infere que, baseado nos resultados da literatura, a inversão das etapas do processo causa uma insegurança jurídica, uma vez que atos administrativos não podem contrariar a lei. Esta, por sua vez, resulta do subsistema dominante para a criação de uma política pública. Portanto, a reforma normativa dos direitos autorais depende da formação de coalizões em prol do acesso aberto que garantam a transformação do status quo de uma política pública que restringe o acesso ao conhecimento para uma política pública que defende a importância das limitações aos direitos autorais para o desenvolvimento nacional. 
Figura 11 - Processo de formação de política institucional de acesso aberto no contexto do direito autoral à luz da ACF.

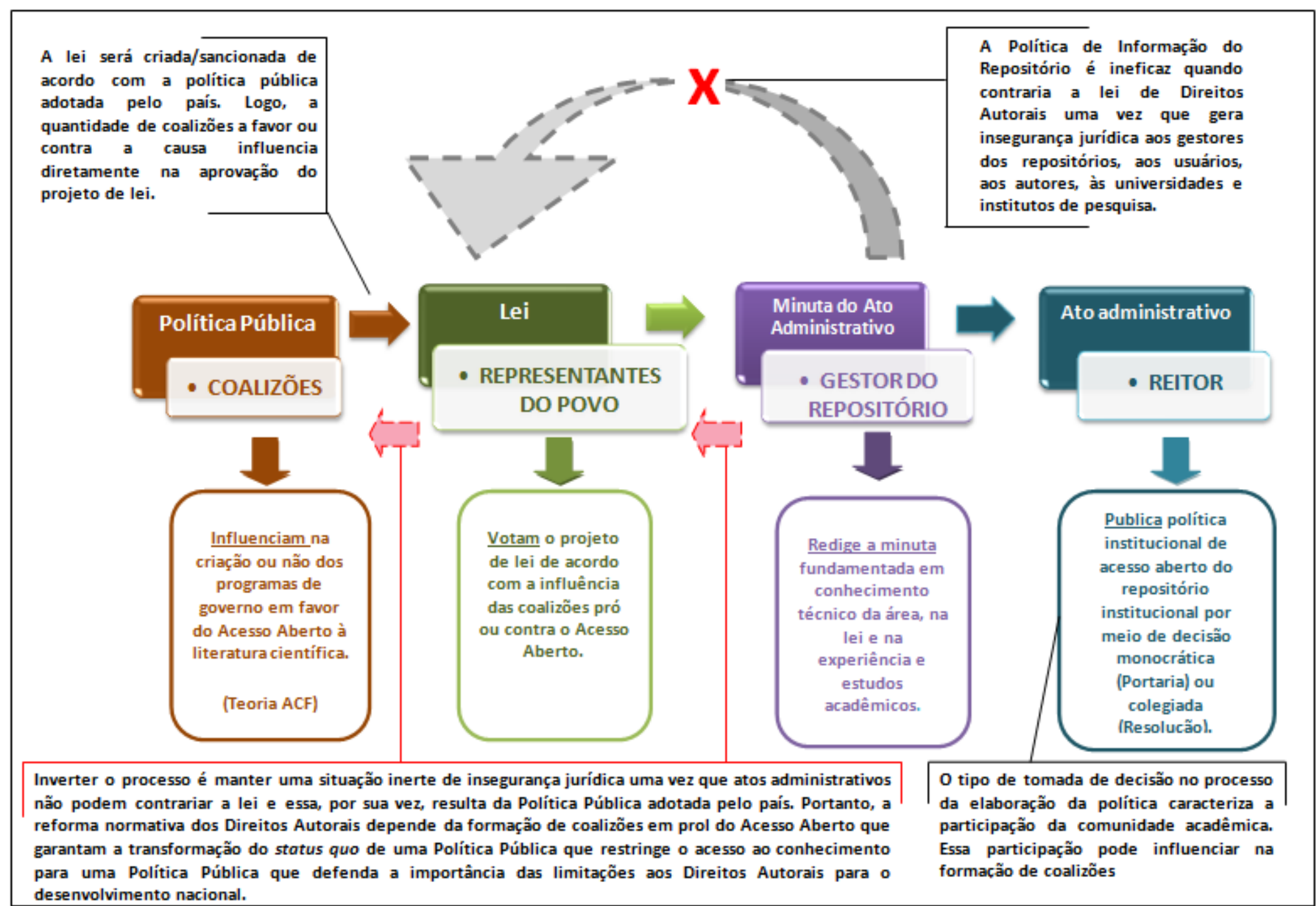

Fonte: a autora (2015). 


\subsection{Percepções e experiências de especialistas}

No decorrer das entrevistas, cujo roteiro derivou da análise da literatura e dos sites de repositórios, foi possível identificar cinco questões que norteiam a extração de elementos estruturantes para a proposição de uma política de direitos autorais para repositórios institucionais de acesso aberto. A primeira refere-se à negociação para a proposição da política. A segunda diz respeito à participação dos docentes na aprovação da política. A terceira consiste na reação da comunidade acadêmica ao instituto do depósito compulsório. A quarta relaciona-se com o suporte oferecido ao autor pela universidade, com relação às questões de direitos autorais. Por fim, há os fatores que contribuem para o sucesso da política de direitos autorais.

A apresentação dos resultados compreende a posição das universidades em relação a cada questão, de acordo com o seu ambiente geográfico e político (Portugal, Estados Unidos e Brasil), os pontos convergentes e divergentes entre elas e, finalmente, a análise.

\section{Questão 1 - Negociação para a proposição da política}

Universidade européia (Portugal): a política foi definida em 2004, um ano após a abertura do repositório. Tendo como inspiração a política da Queensland University, foi elaborada pela equipe do repositório e apresentada ao reitor, que, além de aprová-la, sugeriu a inclusão de incentivos financeiros. Tornou-se efetiva, porém o decréscimo de incentivos financeiros afetou diretamente a quantidade de documentos depositados. A política sofreu revisão em 2010 e o depósito tornou-se obrigatório em 2011, independente de incentivos financeiros.

Universidade americana: a primeira aprovação da política de repositórios aconteceu em 2008, na Faculdade de Direito. O processo de aprovação demorou cerca de dois anos, pois priorizava o esclarecimento do acesso aberto para todos os envolvidos diretos na aprovação. A universidade considera a questão do esclarecimento extremamente importante, pois o conhecimento sobre a causa torna o processo de negociação e implantação mais democrático e, portanto, mais legítimo. Todas as faculdades já têm sua própria política, com exceção da faculdade de medicina, a caminho da aprovação no momento da entrevista. 
Universidade brasileira: a proposta de criação do repositório institucional surgiu em 2004. Em 2009, foram propostas duas políticas: uma sobre repositório e outra sobre depósito compulsório, tendo as duas sido encaminhadas ao Conselho de Ensino, Pesquisa e Extensão - CEPE, que deu parecer favorável apenas para a política do repositório.

\section{Quadro 2 - Negociação para elaboração da política}

\begin{tabular}{|lll|}
\hline \multicolumn{2}{|c|}{ Pontos comuns } & \multicolumn{1}{c|}{ Pontos divergentes } \\
\hline - $\begin{array}{l}\text { Reconhecimento pelos gestores dos } \\
\text { repositórios institucionais sobre a }\end{array}$ & As negociações sobre estratégias de \\
implantação do repositório; & O processo de votação para \\
importância da política para o seu & & aprovação da política. \\
desenvolvimento;
\end{tabular}

Fonte: a autora (2015).

\section{Considerações}

A negociação é fator fundamental para a implantação e, principalmente, manutenção do depósito dos trabalhos científicos em repositório institucional de universidades. Além disso, o esclarecimento acerca do acesso aberto pelas partes envolvidas neste processo reflete diretamente na tomada de decisão para a aprovação ou não da política de direitos autorais. A decisão democrática é tida, para algumas universidades, como condição sine qua non para a detenção de legitimidade na política e, com isso, a criação de cultura de conhecimento científico como bem comum. Entretanto, há, também, o entendimento de que uma decisão monocrática é suficiente para a implementação da política. Ratificando esses argumentos, Tomael e Silva (2007, p.5) afirmam que

Para a definição de uma política para a implantação de um repositório institucional, em que se tomam decisões sobre os serviços a serem oferecidos, é essencial a participação de um grupo com distintas competências e influência na instituição.

Sobre o crescimento dos repositórios, em Portugal percebeu-se um decréscimo no depósito, mas é provável que se deva ao fato de que no primeiro ano de política o repositório teve a inclusão do "passivo" e, portanto, o número de depósitos foi muito elevado. Assim, os depósitos no repositório em Portugal, tiveram, 
nos anos subseqüentes, decréscimo. Já nos Estados Unidos, a cada ano é registrado um crescimento na quantidade de depósito, e esse crescimento, apesar de tímido, é gradual. No caso brasileiro, embora o repositório tenha sido criado em 2004, somente cerca de cinco anos depois é que o depósito começou a ser significativo, após trabalho de sensibilização dos pesquisadores. Desde então, há crescimento constante e gradual - embora lento - dos depósitos.

\section{Questão 2 - Participação dos docentes na aprovação da política}

Universidade européia (Portugal): a formulação da política não foi alvo de discussão pública, sendo elaborada internamente, no Setor de Documentação. A primeira versão foi apresentada para toda a academia, mas com o caráter meramente informativo. A segunda versão montou uma ação nomeada "RoadShow", e apresentou a política para todas as escolas e unidades orgânicas com o objetivo de explicar suas ações e implicações, além de sensibilizar os autores pesquisadores para a iniciativa.

Universidade americana: a política foi formulada pelo Escritório de Comunicação Científica e votada por membros de cada faculdade, não sendo imposta pelos gerentes máximos da instituição. Para o início ou manutenção da política é designado um agente focal, que conhece a legislação de direitas autorias, gestão da informação e por ser ligado à faculdade, também detém conhecimento sobre as peculiaridades daquela área do conhecimento. Tem o objetivo de manter ações continuadas para que o conhecimento do acesso aberto se torne cultural dentro da universidade.

Universidade brasileira: apesar de ter sido proposta por uma docente, não há a participação maciça dos docentes na construção da política, que foi elaborada pelo gestor do repositório com a participação de docentes da área de Ciência da Informação, apenas. A ausência de um Comitê específico indicado para a elaboração da política afeta a tomada de decisão de pontos controversos, como o direito autoral. 
Quadro 3: Participação dos docentes na aprovação da política

\begin{tabular}{|c|c|}
\hline Pontos comuns & Pontos divergentes \\
\hline - Não há. & $\begin{array}{l}\text { - Processo de aprovação: por meio de } \\
\text { voto unitário e voto censitário } \\
\text { (representativo) } \\
\text { - Políticas de divulgação (ações } \\
\text { continuadas e ausência delas) }\end{array}$ \\
\hline
\end{tabular}

Fonte: a autora (2015).

\section{Considerações}

A participação dos docentes na elaboração das políticas foi percebida pelas Universidades brasileira e europeia como uma vertente secundária. Sendo assim, essas universidades não vislumbraram como fator essencial a participação dos docentes haja vista que consideram como importante e eficiente a política em si, independentemente da forma como se deu sua criação. Por um lado, a participação dos docentes na criação da política pode ser vista como um elemento de dificuldade devido ao desconhecimento dos autores pesquisadores sobre questões de direito autoral. Por outro, a decisão democrática legitima a Iniciativa de Acesso Aberto na instituição e, consequentemente, estimula a criação de uma cultura de acesso aberto ao conhecimento. Essa cultura se apresenta como fundamental para o desenvolvimento da Política Nacional de Informação Científica do país. Portanto, a criação de uma política de acesso aberto institucional desenvolve o repositório institucional, mas a criação de uma cultura de acesso aberto prospera na criação de uma Política Nacional de informação científica capaz de criar programas, legislações e campanhas em favor do acesso aberto à comunicação científica.

\section{Questão 3: Reação da comunidade acadêmica com relação ao depósito compulsório}

Universidade européia (Portugal): não houve nenhuma manifestação contrária, mas sim muitas dúvidas por parte da comunidade. Antes de a política se tornar pública, foram convocadas reuniões magnas onde o reitor apresentou o assunto; não sendo conhecido se houve resistência no cumprimento da política. 
Universidade americana: a equipe responsável pelo repositório repassa aos autores informações relevantes sobre as vantagens do depósito do trabalho científico e sobre a manutenção dos direitos autorais patrimoniais e que o depósito não interfere na transferência de seus direitos. Nunca tratam o depósito como obrigatório e tampouco aplicam sanções, pois se trata de uma iniciativa democrática

Universidade brasileira: a política foi publicada, mas não gerou nenhuma repercussão, pois ainda não houve um processo de conscientização da política, não sendo possível mensurar a reação da comunidade. Normalmente, quando determinadas ações são divulgadas, é habitual que os docentes e discentes busquem informações mais aprofundadas. Como a política não foi amplamente divulgada, não há meios de avaliar as diferenças e o impacto com relação ao depósito compulsório.

Quadro 4: Reação da comunidade acadêmica

\begin{tabular}{l} 
Pontos comuns $\quad$ Pontos divergentes \\
\hline
\end{tabular}

- Todas as políticas são mandatórias,

- Não foi possível identificar, uma vez até mesmo nos Estados Unidos, onde que no Brasil a reação da comunidade ainda não foi avaliada é considerada democrática

Fonte: a autora (2015).

\section{Considerações}

A universidade europeia trabalhou bastante na publicidade e disseminação da informação referente ao depósito de trabalhos acadêmicos no seu repositório institucional. Apesar de a política ter sido imposta de forma monocrática, ou seja, pela a administração da universidade, a quantidade de depósitos informada na entrevista e publicada na literatura demonstra o sucesso das suas ações. Importante ressaltar que políticas semelhantes adotadas por universidades de países próximos territorialmente e culturalmente devem influenciar na adesão da política visto que levam segurança por meio de exemplos práticos.

Já a Universidade americana preza pelo ato democrático. Logo, sua política, como já mencionado, foi legitimada por meio do voto da comunidade acadêmica. 
Esse discurso, trazido por seus gestores, tende a elevar esse tipo de estratégia perante os autores americanos. Isso porque, apesar de a negociação da aprovação da política ter sido ser distinta entre Portugal e Estados Unidos, o depósito no repositório institucional descrito nas políticas da universidade americana integra o mesmo texto utilizado nas políticas de depósito compulsório das européia e brasileira.

A universidade brasileira publicou sua política após uma decisão da administração. Entretanto, ainda não teve como mensurar a aceitação de seus membros, devido à ausência de ações ad hoc que disseminem o conhecimento acerca da Iniciativa de Acesso Aberto e os Direitos Autorais.

Nesse contexto, então, faz-se a distinção entre o tipo de negociação (monocrática ou democrática) e tipo de depósito (compulsório ou não compulsório). São classificações distintas, mas que, combinadas, definem a estratégia de implementação e manutenção da política institucional de acesso aberto do repositório institucional.

\section{Questão 4: Suportes oferecidos ao autor pela universidade ou biblioteca da universidade com relação às questões de direitos autorais}

Universidade européia (Portugal): surgiram muitas dúvidas em relação ao copyright. O depósito é obrigatório, mas o tipo de acesso é variável. Se os autores tiverem algum impedimento para depositar (contrato com terceiros - editoras) ainda podem fazer o depósito. Portanto, a maior dificuldade está relacionada com as questões de direito autoral. A universidade criou um website sobre direitos de autor que serve como apoio no esclarecimento de dúvidas.

Universidade americana: não é oferecido apoio jurídico efetivo, mas existe um apoio em relação a questionamentos pontuais e, quando o autor solicita, é feito um acompanhamento nas negociações com editoras. Existe ainda um projeto, em vias de ser lançado, "Socorristas em direito autoral" - fazendo uma analogia com a emergência médica - já que os membros da universidade possuem emergências também, pois as editoras por vezes, determinam prazos de um ou dois dias para os contratos serem assinados; este projeto será realizado por meio de escritório central alocado pela biblioteca. 
Universidade brasileira: a biblioteca oferece todo o apoio possível e a maioria das dúvidas se concentra na questão das licenças públicas. Normalmente o autor quer depositar um trabalho que já foi publicado em revistas científicas comerciais, sem saber que já não detém a titularidade dos direitos daquele trabalho. A biblioteca o orienta nesse sentido, mas não tem o poder de capacitar para decisões futuras. Mesmo a participação de um especialista da área de direitos autorais sendo ideal é inviável, pois a criação do Comitê Gestor não previu a participação desse profissional.

\section{Quadro 5: Suporte oferecido pela universidade}

\begin{tabular}{|c|c|}
\hline Pontos comuns & Pontos divergentes \\
\hline $\begin{array}{l}\text { - Desconhecimento por parte dos } \\
\text { autores com relação às questões de } \\
\text { direitos autorais; } \\
\text { - Reconhecimento da importância do } \\
\text { apoio da universidade aos seus } \\
\text { membros; } \\
\text { Efetivo apoio por meio de ações } \\
\text { pontuais ou de comunicação }\end{array}$ & - Ausência de equipe capacitada \\
\hline
\end{tabular}

Fonte: a autora (2015).

\section{Considerações}

O apoio da universidade com relação às questões de direitos autorais tem se apresentado como fundamental para o sucesso da Iniciativa de Acesso Aberto nos repositórios institucionais. Dentre as formas de o apoio que a universidade pode oferecer estão as campanhas educativas, incentivos financeiros e a assistência/orientação jurídica.

O desconhecimento do autor a respeito dos seus direitos aparenta ser uma grave ameaça ao depósito da sua produção intelectual nos repositórios institucionais. Isso porque a falta de clareza sobre o assunto tende a gerar insegurança jurídica nos autores. Por isso, Portugal e Estados Unidos buscaram se antecipar com o propósito de educar os seus docentes e pesquisadores nas questões de direitos autorais. 
As entrevistas apontaram que existem pelo menos dois tipos de educação dada aos autores pelas instituições: a educação coletiva e a educação pontual ou ad hoc. A educação coletiva tem o fim de atingir o máximo de membros e é realizada por meio de campanhas, notícias, eventos, assembleias e reuniões. Já a educação ad hoc é aquela que tem a intenção de esclarecer uma questão pontual de um caso concreto mediante uma assistência jurídica especializada.

As universidades européia e americana não só demonstraram preocupação com o assunto como também planejaram e executaram ações comprometidas a solucionar ou, pelo menos, amenizar a falta de esclarecimento dos autores. A Universidade brasileira, apesar de entender e reconhecer a importância do tema, ainda não tem condições para executar ações que envolvam a educação "ad hoc".

Esse ponto se mostrou relevante para a mudança ou criação de cultura, uma vez que é a partir do conhecimento do autor sobre os direitos autorais que haverá a possibilidade ou não do depósito da sua obra em um repositório institucional de acesso aberto.

\section{Questão 5: Fatores que contribuem para o sucesso da política de direitos autorais}

Universidade européia (Portugal): incentivo orçamentário estatal no início, o que contribuiu para o crescimento da quantidade de depósitos feitos no repositório; ações informativas que geram conhecimento e esclarecem dúvidas; comunicação e investimento em ações que discutem o tema, e aumentam a visibilidade dada aos trabalhos depositados no repositório.

Universidade americana: o tipo de negociação utilizada para implantar a política de maneira que se crie uma cultura e não uma regra (negociação democrática); comunicação interna para a divulgação do acesso aberto, para cativar os interessados no assunto e conquistar apoiadores e tornar possível a prática da política; educação sobre questões autorais e a participação ativa da biblioteca.

Universidade brasileira: um especialista na área de direitos autorais, para analisar as demandas, criar estratégias de comunicação e levar segurança para a equipe no momento da tomada de decisão; uma política efetiva e didática que aborde as questões de direitos autorais; política de recompensa e não de penalidade, para 
auxiliar na criação de uma cultura e criar o hábito do compartilhamento científico; elaboração de um manual, ou instrumentos educativos, para auxiliar e esclarecer sobre a temática do acesso aberto.

\section{Quadro 6: Fatores que contribuem para o sucesso da política}

\begin{tabular}{|c|c|}
\hline - Pontos comuns & - Pontos divergentes \\
\hline $\begin{array}{l}\text { - Implantação ou criação de uma } \\
\text { cultura de acesso aberto à } \\
\text { comunicação científica; } \\
\text { - Necessidade de ações educativas } \\
\text { sobre questões de direitos autorais; } \\
\text { - Divulgação/ comunicação de } \\
\text { instrumentos capazes de esclarecer } \\
\text { conceitos e fluxos de atividades. }\end{array}$ & $\begin{array}{l}\text { - Incentivo estatal; } \\
\text { - } \quad \text { Negociação democrática; }\end{array}$ \\
\hline
\end{tabular}

Fonte: a autora (2015).

\section{Considerações}

Os gestores dos repositórios institucionais das três universidades compartilham quase as mesmas opiniões acerca dos fatores que contribuem para o sucesso da política de direitos autorais. Percebe-se que as práticas descritas nem sempre estão relacionadas com as questões de direitos autorais. Isso porque essa confusão entre o que está e o que não está relacionado com a política de direitos autorais dos repositórios institucionais de acesso aberto deixaram de ser relevantes no momento em foi percebido que o acesso aberto está intrinsecamente relacionado ao "poder" e ao "não poder" no momento do depósito e, principalmente, no momento da disponibilização daquele conteúdo.

A forma de negociação foi apontada pela universidade americana como importante para conscientização dos autores e pesquisadores sobre a iniciativa do acesso aberto. Isso porque a inclusão do membro nessa tomada de decisão por meio do voto favorece sua inclusão no processo e, possivelmente, na criação de uma cultura. 
A falta de autonomia dos autores, gerada pelo desconhecimento com relação aos seus direitos, é tida como uma das maiores ameaças para o movimento do acesso aberto, já que se sentem intimidados pelos editores nesta situação. Certamente por isso os gestores foram unânimes e, muitas vezes, repetitivos ao inserir a educação como fator de sucesso para o repositório institucional de acesso aberto.

A sanção não foi bem vista como um incentivador pelos gestores das universidades estudadas, possivelmente pela cultura da instituição ou pelo receio de ter um afastamento do autor ao invés de uma aproximação.

Além desses fatores, a atividade da biblioteca também foi mencionada e aqui cabe uma citação da entrevista realizada nos Estados Unidos

[...] outro papel principal dos bibliotecários no movimento do acesso aberto é que eles estão melhores informados sobre acesso aberto do que qualquer outro grupo. Se falarmos de grupos como classes, então diria que estão melhores informados do que qualquer outro grupo, e como classe estão melhores informados do que os demais membros da universidade, melhores informados do que editores, melhores informados do que gestores de fundações, melhores informados do que os legisladores. Então eles podem informar aos demais membros da universidade, eles podem informar aos administradores sobre o que é acesso aberto e sobre o que não é. Eles podem ajudar a corrigir erros que foram espalhados por editores.

Nota-se que o bibliotecário é, atualmente, o profissional mais envolvido com o tema e, por isso, sua importância para o sucesso da Iniciativa do Acesso Aberto. Porém, é necessário que tenha noção de direitos autorais e conte com um especialista no assunto na sua equipe para que o auxilie nas tomadas de decisões e esclareça as dúvidas dos autores.

O apoio da instituição com relação às ações educativas, esclarecimentos pontuais e assistência na negociação entre autores e editoras também foi reconhecido fator como fundamental para o sucesso, além de serem consideradas como parte de uma educação continuada.

É possível auferir das entrevistas, também, que os gestores conhecem os fatores que influenciam no sucesso da política de direito autoral, mas que o próprio 
gestor do repositório ainda não domina o direito de autor, apesar de reconhecer a sua importância.

\subsection{Políticas dos repositórios}

Os documentos utilizados na pesquisa foram as políticas institucionais dos repositórios institucionais de universidades brasileiras registradas no ROARMAP e publicadas em veículo oficial. A análise seguiu a metodologia adotada na pesquisa, portanto, a categorização das políticas foi feita a partir da condensação dos textos completos de cada política. Buscou-se verificar a existência de pontos comuns e divergentes sobre dezoito categorias, listadas a seguir. A categorização e a interpretação tiveram o objetivo de traçar uma comparação com os resultados obtidos nas entrevistas.

\section{Data de publicação}

A partir da publicação de cada política é possível traçar uma linha cronológica (figura 12). Observa-se que todas as universidades basearam os textos de suas políticas na Declaração de Berlin.

Figura 12 - Linha cronológica de publicação das políticas institucionais de informação de repositórios digitais das universidades brasileiras

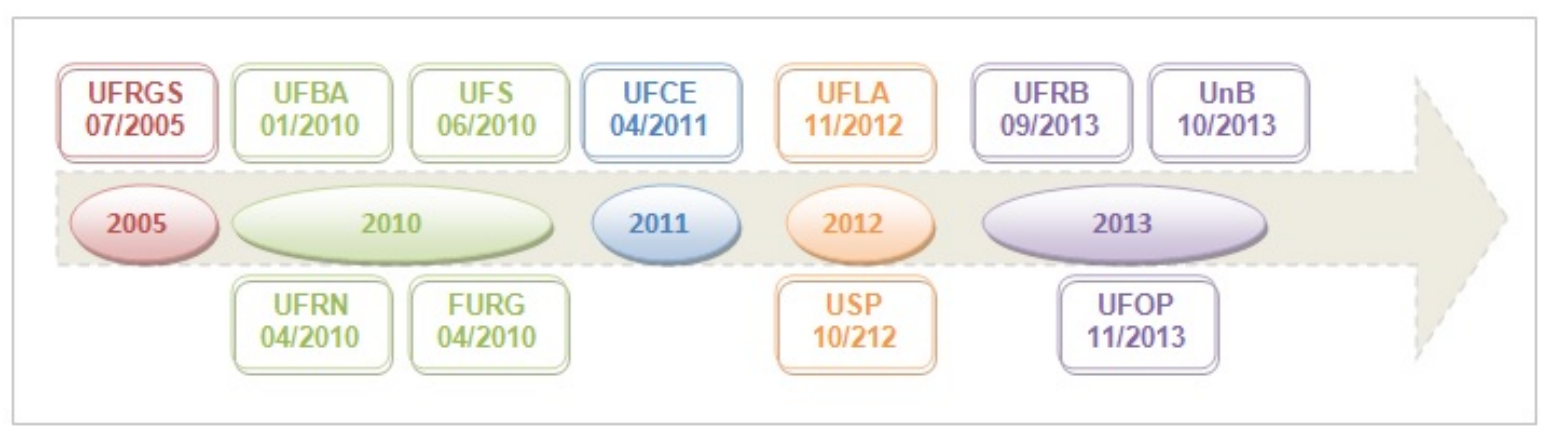

Fonte: a autora (2015).

\section{Tipo de ato administrativo utilizado para a publicação}

Com exceção da UFBA e UFRB, que publicaram suas políticas de informação institucional por meio de uma portaria, todas as universidades utilizaram a resolução para estabelecer sua política de informação. É pertinente considerar que as publicações por resolução são decisões advindas do colegiado da universidade, podendo-se supor que houve a participação dos docentes na elaboração da política 
de cada universidade, ainda que não seja possível estimar se foi uma participação maciça ou não.

\section{Identificação do documento}

UnB, UFRN, UFOP e UFLA nomeiam o documento de Política de Informação Institucional. A UFCE nomeia de Política Institucional de Informação Técnicocientífica. A UFS, de Política de Acesso Livre à Informação Científica. A UFBA e UFRB, de Política do Repositório Institucional. A FURG, de Política institucional de Informação. A USP e a UFRGS não identificam o documento.

\section{Finalidades do RI}

Com exceção da UFRN, que não contextualizou a finalidade do RI, todas as universidades definiram as finalidades de seus repositórios como a preservação de sua memória institucional e ampliação do acesso à literatura científica na universidade. UnB, USP, UFLA, UFOP, UFRB, UFBA e UFCE ainda visam a potencializar o intercâmbio entre a universidade e outras instituições

\section{Definição de obra intelectual}

A UnB, a UFRN e a UFCE definiram obra intelectual como os resultados consolidados e publicados em veículos de comunicação científica, revisados por pares. A UFCE define, ainda, os documentos que são considerados como tal: artigos publicados em periódicos científicos, teses e dissertações, livros e capítulos de livros, trabalhos apresentados em eventos científicos e acadêmicos e produção cultural oriunda de trabalhos acadêmicos e científicos. A FURG e a UFRB consideram como obra intelectual toda e qualquer produção técnica-científica revisada por pares. As demais universidades não apresentam a definição em suas políticas.

\section{Competência atribuída à biblioteca}

Com exceção da UFRN, da UFLA, da UFBA e da FURG, todas as universidades atribuíram alguma responsabilidade às bibliotecas. $\mathrm{Na}$ UnB, na UFOP e na UFS, a biblioteca tem o poder de implantar, desenvolver e manter os repositórios institucionais no âmbito da universidade. Na UFCE a biblioteca faz parte 
do comitê gestor para a implantação e manutenção do repositório. Na UFRGS e na UFRB a biblioteca é responsável por receber todos os trabalhos acadêmicos produzidos no âmbito da universidade. Na USP existem as atribuições do Conselho Supervisor do Sistema Integrado de Bibliotecas, que ficam a cargo de estabelecer e validar as normas para coleta, tratamento e preservação da produção intelectual gerada na universidade. Mais que isso, são definidos os tipos de documentos para o depósito e as atribuições da biblioteca, registrada a produção intelectual, editada, revisada e validada a produção intelectual auto-arquivada pelo autor e atualizados permanentemente os registros da produção intelectual.

\section{Tipo de acesso à informação}

Todas as universidades concedem como livre o acesso ao repositório institucional, tanto no contexto nacional como internacional. Porém, UFRGS e UFS determinam que a disponibilização do conteúdo seja feita mediante autorização do autor. Já a USP estabelece que o acesso poderá ser aberto, embargado, restrito para uso nos computadores da universidade, ou restrito completamente. O depósito tem apenas fins de gestão e governança da produção.

\section{Autorização para a publicação}

A UFRGS estabelece que o termo de autorização deva ser preenchido pelo autor, acompanhado dos documentos em formato impresso e eletrônico, em conformidade com a LDA. Na UFCE o autor deve garantir à universidade o direito de preservar e distribuir o trabalho por meio do repositório institucional, mediante as condições estabelecidas no termo de autorização assinado pelo mesmo. A UFS determina que o autor assine o termo de consentimento para a realização do depósito, que concede permissão para depositar, distribuir e preservar o material depositado. Por fim, a UFRN estipula que a assinatura do termo de autorização será eletrônica após o registro no RI. As outras universidades não apresentaram texto específico para a autorização.

\section{Interoperabilidade do sistema}

UFRGS e UFLA não apresentam cláusulas que tratam da interoperabilidade do sistema. As demais universidades apresentam textos bem similares, e afirmam 
que o sistema do repositório deverá ter capacidade de integração com sistemas nacionais e internacionais, além de observar o uso de padrões e protocolos de integração. USP ainda estabelece que deva ser assegurada a integração do sistema com os sistemas corporativos da universidade.

\section{Software}

Apenas UnB e USP informaram como funcionará o repositório. A primeira tem sua plataforma desenvolvida em software livre, em consonância com os princípios do acesso aberto. Já a segunda utiliza o banco de dados "Deadalus".

\section{Orientação contratual}

Na UFS, na UnB, na USP, na UFRB, na UFBA e na UFOP a orientação é que os autores publiquem seus trabalhos em periódicos científicos de acesso aberto, ou que especifiquem nos contratos a autorização para o depósito em repositórios de acesso aberto. Na UFS, na UFBA e na UFRN é pedido que o autor deposite uma cópia original do trabalho (pré-prints) quando houver a impossibilidade de realização do depósito devido ao contrato mantido pelo autor com a revista onde o trabalho foi publicado.

\section{Embargos}

Na UFCE, na USP, na UFRN, na UFBA e na UFOP o depósito pode ser imediato quando não houver impedimentos junto à revista científica, caso contrário, o depósito deve ser feito em até seis meses da data de publicação do artigo. $\mathrm{Na}$ UnB, essas orientações também devem ser seguidas, salvo quando o contrato com a editora exigir um tempo maior, caso em que o depósito deve ser feito no mês subseqüente ao fim do prazo estipulado no contrato. Na USP o depósito fica embargado por tempo limitado no contrato assinado pelo autor e pela editora. Importante destacar que na política da FURG não está previsto cláusulas de embargo.

\section{Isenções e desobrigações do depósito no repositório institucional}

As universidades UFCE, UFS, UFLA, UnB e UFOP desobrigam o depósito de livros ou capítulos de livros que tenham fins comerciais, obras negociadas com 
restrições contratuais relativas aos direitos autorais, artigos publicados em revistas científicas que impedem o depósito do trabalho em repositórios de acesso aberto (direito patrimonial exclusivo) e documentos cujo conteúdo seja resultado de pesquisas passíveis de serem patenteadas. A UnB e a UFOP ainda estabelecem que somente serão distribuídos, eletronicamente pelo repositório, documentos que a autorização tenha sido concedida pelo detentor dos direito patrimoniais da obra. Não há previsão de isenções na política da FURG e da USP.

\section{Depósito compulsório}

Na UFRGS toda tese, dissertação ou trabalho de conclusão de graduação ou especialização produzido no âmbito da universidade deverá ser entregue à biblioteca em formato impresso e eletrônico acompanhado do termo de autorização assinado. Na UFCE, na UFS, na UnB, na UFRN e na UFOP devem ser depositados todos os documentos que não se enquadram nas isenções/ desobrigações, e que foram publicados em periódicos científicos revisados por pares ou avaliados por especialistas. Na USP ficou estabelecido que docentes, técnico-administrativos, alunos e pós-doutorandos devem depositar o conteúdo integral de seus trabalhos na medida em que forem publicados ou editados. O depósito da FURG será formado por toda a produção intelectual de autoria ou co-autoria de servidores da universidade

\section{Responsabilidade pelo depósito mediado ou autodepósito}

Na UFCE, na UFRN, na USP, na UFOP, na UFBA e na UnB a biblioteca pode efetuar o depósito da obra mediante autorização do autor, seja por entrada de documento ou importando os dados de outro repositório. Na USP o autor também pode inserir o conteúdo através do auto arquivamento.

\section{Responsabilidade pela gestão da política}

A UnB designou um Comitê Gestor. A UFRN e a UFCE designaram uma comissão, formada por representantes da Pró-reitoria de pesquisa, da biblioteca, da comunicação e da informática (as duas universidades apresentam a mesma composição). A USP criou o Conselho Supervisor do Sistema Integrado de Bibliotecas e a UFS dividiu as tarefas entre biblioteca, pró-reitoria de pesquisa e 
centro de processamento de dados. A UFBA designou um grupo gestor, mas não especificou quais áreas o comporão. A UFRB estabeleceu que a competência seja de duas coordenações: informação e documentação e tecnologia da informação. $O$ comitê gestor da FURG é composto apenas por servidores de pró-reitorias e informática, não havendo a presença nem participação da biblioteca. Não foi possível identificar as responsabilidades pelo acompanhamento da gestão da política nas outras universidades.

\section{Ações para o cumprimento da política}

UFRN, UFOP, UFBA, UFRB e UFCE estabelecerão mecanismos de estímulos, bem como ações de integração que possibilitem evitar a duplicação de esforços. As demais universidades não informaram as medidas a serem tomadas nesse ponto.

\section{Vacatio legis}

Todas as políticas entram em vigor na data de sua publicação.

\subsection{Modelo conceitual resultante da pesquisa}

O estudo permitiu a proposição de modelo conceitual (figura 13) que embute teoria que estabelece que a formulação da política de direito autoral e sua inserção na política de acesso aberto para repositórios institucionais requerem levar em conta três dimensões essenciais. Tais dimensões visam ao melhor entendimento da questão específica do direito autoral nesse contexto. Mais que isso, contribuem para identificação dos elementos essenciais à estruturação da política.

A dimensão legal trata dos pontos referentes ao termo de autorização, o tipo de acesso, o embargo, o depósito compulsório e a desobrigação de depósito e a disponibilização do conteúdo. A dimensão institucional envolve três elementos da política de informação de repositórios institucionais de acesso aberto, nomeadamente, finalidade do repositório institucional, conceito de produção científica, e competências dos setores envolvidos na elaboração e acompanhamento da política. A dimensão tecnológica está relacionada com a interoperabilidade, os software utilizados e suas respectivas licenças. As três dimensões, portanto, compõem os aspectos necessários à formulação da política de direito autoral 
embutida na política de informação para os repositórios institucionais de acesso aberto de universidades.

Observe-se que as dimensões não estão isoladas, mas interferem umas nas outras, criando uma zona de convergência de onde se extraem as questões de direitos autorais. Trata-se de ações estratégicas que levam a uma proposta de elementos estruturantes necessários à elaboração de política de direito autoral para repositórios institucionais de acesso aberto.

São três os elementos etruturantes. O primeiro diz respeito à política pública de acesso aberto, resultante do trabalho de coalizões que fortalecem a questão da advocacy (grupos bem estruturados para defesa do acesso aberto). Tal política, por sua vez, influencia a elaboração da lei de direito autoral. O segundo refere-se à própria política institucional de direitos autorais, a qual compreende alternativas de negociação à luz do direito administrativo e da legislação vigente entre a instituição, os autores e os editores. Finalmente, o terceiro elemento relaciona-se com a educação (conscientização) dos pesquisadores, na forma de incentivos, campanhas e assessoria, visando à sensibilização destes sobre as questões de acesso aberto.

Como pesquisa qualitativa, o modelo conceitual da pesquisa foi construído a partir dos dados extraídos do que diz a literatura, os sites dos repositórios e as percepções e experiências de especialistas. Permitem, assim, que sua proposição tenha sido feita a posteriori, como indicam Glaser e Strauss (1967), ao tratarem da assim chamada Teoria Fundamentada (Grounded Theory). Nesse sentido, ressaltase o que afirmam Strauss e Corbin (1990, p. 23)

Uma Teoria Fundamentada é aquela derivada indutivamente do
estudo do fenômeno que representa. Isto é, ele é descoberto,
desenvolvido e provisoriamente verificado por meio de sistemática
coleta e análise de dados. Portanto, a coleta de dados, análise e
teoria possuem relação recíproca entre si. Não se começa com uma
teoria para prová-la. Começa-se com uma área de estudo em que se
permite a emersão do que é relevante.

Embora a Teoria Fundamentada não tenha se constituído na metodologia determinante do presente estudo, seus princípios se aplicam no modo como foi conduzido o aproveitamento dos resultados obtidos. 
Figura 13 - Modelo conceitual resultante da pesquisa

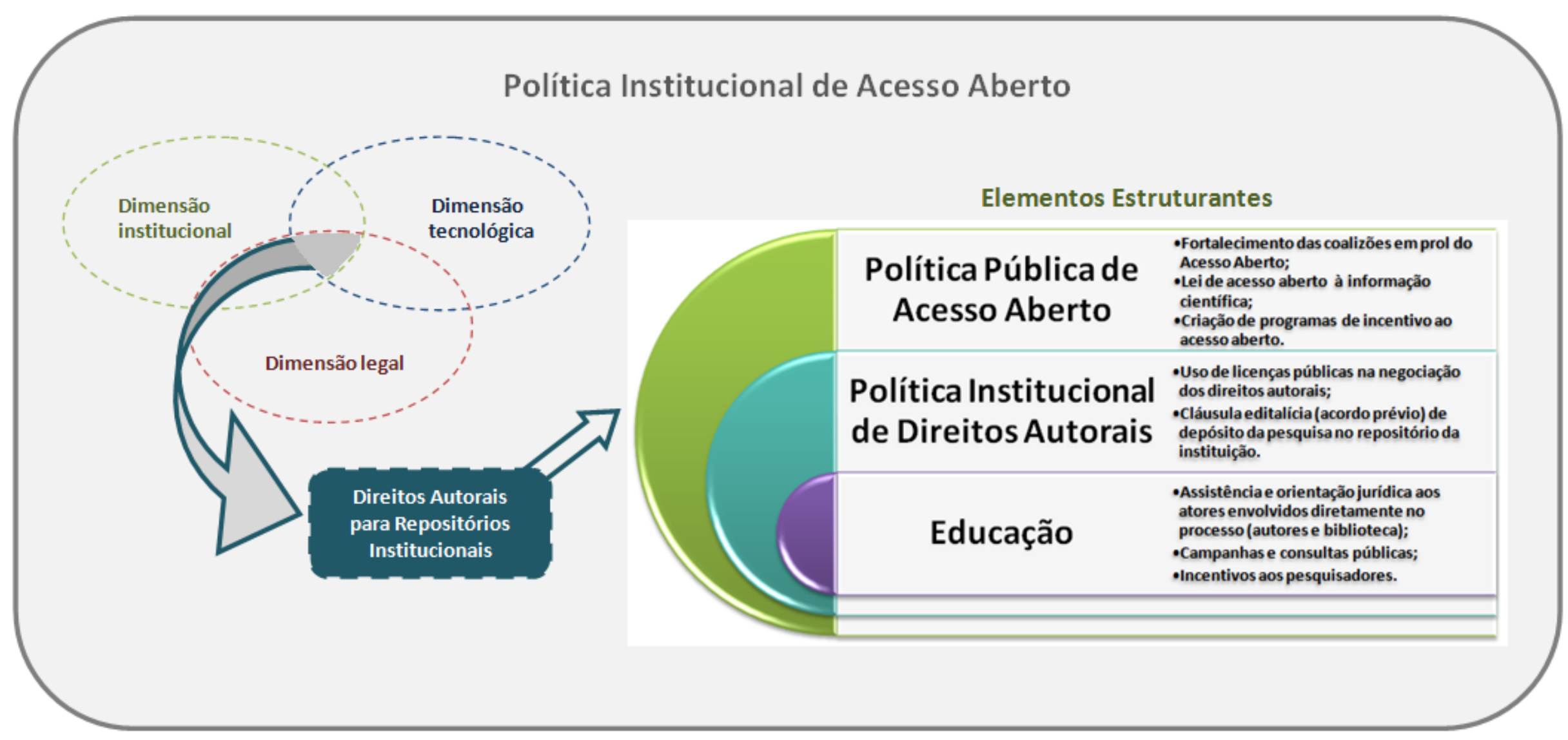

Fonte: a autora (2015) 


\section{CONCLUSÃO}

\subsection{Introdução}

Este capítulo apresenta, a partir dos resultados obtidos no presente estudo, as principais concusões deles derivadas. Tais conclusões estão apresentadas com base nos objetivos da pesquisa. Primeiramente, uma concusão geral, seguida das conclusões relacionadas a cada objetivo específico proposto.

\subsection{Elementos estruturantes para políticas institucionais de direito autoral}

O objetivo geral do presente estudo foi apresentar, com base na análise da literatura, das políticas de repositórios de acesso aberto de universidades brasileiras e das percepções e experiências de gestores de repositórios de três países e de um especialista, elementos estruturantes necessários à formulação de políticas de direito autoral para repositórios de acesso aberto de universidades. Os resultados obtidos permitem concluir que são necessários três elementos apropriados à estruturação de políticas de direito autoral para repositórios institucionais de acesso aberto, nomeadamente, políticas públicas, políticas institucionais e educação. Mais que isso, tanto a literatura quanto os documentos analisados e as entrevistas mostraram que as questões de direito autoral fazem parte das políticas institucionais de acesso aberto e compreendem os aspectos legal, tecnológico e institucional.

\subsection{Questões relevantes da fundamentação teórica}

As questões relevantes à fundamentação teórica sobre direito autoral no contexto do acesso aberto envolvem tanto mudanças no processo de comunicação científica quanto o surgimento de novos paradigmas do direito autoral.

\subsubsection{Processo de comunicação científica}

No que concerne a mudanças no processo de comunicação científica, é possível concluir, com base nos resultados da pesquisa, que:

- nos dias atuais e daqui por diante, não é possível ilustrar o processo de comunicação científica sem levar em conta questões do direito autoral;

- em razão da filosofia do acesso aberto, entende-se que direitos autorais não se transferem/cedem: são licenciados para uso; 
- a depender de diferenças disciplinares, a inserção da etapa de negociação dos direitos autorais pode requerer mudança estrutural no processo de comunicação científica;

- a questão do direito autoral requer mudanças nos atores do processo de comunicação científica, que deixam de ser indivíduos ou instituições, passando a se constituírem em colalizões.

\subsubsection{Direito autoral}

Quanto às questões do direito autoral, é possível concluir:

- diferentemente do sistema comercial (copyright) adotado nos Estados Unidos, o sistema de direito autoral brasileiro é o unionista (droit d'auteur), adotado pela maioria dos países Europa;

- embora signatário da convenção de Berna, a legislação vigente no Brasil contraria a questão do uso justo (fair use) da obra;

- o ato administrativo que regulamenta a política institucional de acesso aberto deve resultar de minuta elaborada por gestores de repositórios, os quais devem elaborar as minutas levando em conta a legislação de direitos autorais do país, que deve resultar de uma política pública produzida a partir da formação de coalizões que a influenciam;

- a inversão do processo de elaboração da política institucional de acesso aberto causa situação de flagrante anomalia constitucional;

- licenças públicas de direitos autorais constituem opção de negociação desses direitos entre autores e seu público, sem intermediários (novos paradigmas do direito autoral);

- a ausência de coalizões impede a reforma da legislação de direitos autorais no Brasil;

- a ausência de política pública de acesso aberto no Brasil impede a elaboração de políticas institucionais efetivas.

\subsection{Políticas institucionais de acesso aberto}

Os resultados obtidos das análises das entrevistas e dos sites dos repositórios permitem derivar as conclusões a seguir, com base nas categorias identificadas.

\subsubsection{Negociação na elaboração das políticas}

A negociação entre todos os atores envolvidos para elaboração da política institucional de acesso aberto: 
- constitui fator fundamental para sua implementação;

- facilita a tomada de decisão em razão do esclarecimento das partes envolvidas;

- aufere-lhe legitimidade.

\subsubsection{Participação dos docentes na elaboração da política}

A participação dos docentes das universidades na elaboração da política de acesso aberto:

- dificulta a criação da política, caso desconheçam as questões do acesso aberto e dos direitos autorais;

- estimula cultura de acesso aberto, caso conheçam as questões do acesso aberto e dos direitos autorais;

- depende da educação (conscientização) dos pesquisadores da universidade, pois constitui fator fundamental para o êxito da política institucional de acesso aberto.

\subsubsection{Reação da comunidade acadêmica ao depósito compulsório}

A reação da comunidade acadêmica ao depósito compulsório depende do tipo de negociação adotado. Isso quer dizer que:

- a negociação do depósito compulsório pode ser monocrática ou democrática;

- a estratégia adotada influencia a reação favorável ou não ao depósito compulsório;

- a negociação democrátia influencia favoravelmente o depósito compulsório.

\subsubsection{Apoio aos autores}

O sucesso das iniciativas com repositórios institucionais depende fundamentalmente do apoio oferecido pela universidade e suas bibliotecas aos autores, porque:

- a conscientização para sensibilização dos autores pode ser realizada ad hoc o coletivamente;

- tanto a conscientização ad hoc quanto a coletiva são efetivas no apoio ao autor para depósito de seus trabalhos nos repositórios de suas instituições; 
- a inclusão de especialista em direitos autorais nas equipes dos repositórios constitui fator de sucesso na assistência jurídica a autores;

\subsubsection{Contexto brasileiro}

No contexto brasileiro, os resultados obtidos por meio da análise dos sites dos repositórios permitiram concluir que:

Todas as políticas institucionais de acesso aberto são publicadas por meio de portaria ou resolução assinadas pelo reitor;

- a maioria se fundmenta em decisão democrática;

- a maioria obriga o depósito, mas desobriga nos casos de contratos restritivos já realilzados, mostrando-se ineficazes;

- há flagrante inconstitucionalidade nas políticas que não desobrigam o depósito;

- a biblioteca é o principal órgão gestor dos repositórios institucionais das universidades brasileiras;

- a maioria das universidades brasileiras comete equívoco relevante ao nomear as políticas como "de informação";

\subsection{Elementos necessários à política}

No que concerne aos elementos necessários à política de direito autoral, os resultados obtidos por meio da análise da literatura, dos sites dos repositórios e das entrevistas, permitem concluir que:

- diferentemente do que se identifica nas políticas dos repositórios institucionais de universidades brasileiras, a política de direitos autorais não se restringe às questões legais, mas incluem, necessariamente, questões institucionais e tecnológicas;

- é necessário que a política de direito autoral das universidades fundamente-se em política pública, em política institucional e na educação dos autores.

\subsection{Contribuições do estudo}

O presente estudo permite destacar, como previsto em sua justificativa inicial, que sua conclusão mostra dois tipos de contribuição. A primeira, de ordem teórica, 
diz respeito à discussão sobre questões de direito autoral no contexto da comunicação científica e do acesso aberto. Considerando-se que tal discussão não tem sido aprofundada na Ciência da Informação, as discussão tal como apresentada no estudo, contribui para o avanço do conhecimento a respeito dessa questão, que tem se mostrado como a mais relevante nessas discussões. A segunda, de ordem prática, refere-se a, pelo menos, dois aspectos. O primeiro, diz respeito às discussões sobre a legislação brasileira e a condução das políticas públicas no país, com destaque para a necessidade de coalizões fortes que contribuam para o sucesso das ações. O segundo diz respeito às orientações e diretrizes úteis a gestores de repositórios institucionais de universidades brasileiras. É importante notar que as conclusões do estudo no contexto das universidades podem, mutatis mutantis, ser aplicadas no contexto de institutos de pesquisa.

\subsection{Sugestões para futuros estudos}

Os resultados obtidos no presente estudo, embora se restrinjam ao contexto brasileiro, podem ser expandidos para países cuja realidade, ordenamento jurídico ou outro fator se assemelhem à realidade brasileira. Adicionalmente, sugere-se a aplicação do modelo modificado de Hurd (2004) a divisões do conhecimento em que as diferenças disciplinares apontam para diferenças em relação ao depósito em repositórios e necessidade de negociação dos direitos autorais. 
ABRAÃO, Eliane Yachouh. Direitos de autor e direitos conexos. São Paulo: Editora do Brasil, 2002.

ACEMOGLU, Daron; ROBISON, James. Porque as nações fracassam: a origem do poder, da prosperidade e da pobreza. Rio de Janeiro: Elsevier, 2012.

AFONSO, Otávio. Direito autoral: conceitos essenciais. Barueri: Manole, 2009.

ALMEIDA, Marcelo Cavalcanti. Auditoria: um curso moderno e completo. 7.ed. São Paulo: Atlas, 2010.

ARAÚJO, Edmir Netto de Araújo. Proteção judicial do direito de autor. São Paulo: LTr, 1999.

ARAÚJO, Edmir Netto de Araújo. Proteção judicial do direito de autor. 2. ed. São Paulo: LTr, 2004.

ARAYA, Elizabeth Roxana Mass; VIDOTTI, Silvana Aparecida Borsetti Gregorio. Direito autoral e tecnologias de informação e comunicação no contexto da produção, uso e disseminação de informação: um olhar para as Licenças Creative Commons. Inf. \& Soc.:Est., João Pessoa, v.19, n.3, p. 39-51, set./dez. 2009.

ARNOLD, Morris et al. Patent, trademark and copyright. v.19. Washington, DC: Bureau of National Affairs, 1995.

ASCENSÃO, José de Oliveira. O direito de autor como direito da cultura. In OMPI. Um novo mundo de Direito de Autor? Congresso Ibero-Americano de Direito de Autor e Direitos Conexos, 2. Anais. Tomo II. Lisboa: OMPI/Cosmos, 1994.

ASCENSÃO, J. O. Direito autoral. 2. ed., ref. e ampl. Rio de Janeiro: Renovar, 1997.

AVANCINI, Helenara Braga. Perspectivas atuais do direito da propriedade intellectual. Porto Alegre: PUCRS, 2009. 236 p.

BALBACHEVSKY, Elizabeth. A pós-graduação no Brasil: novos desafios para uma política bem sucedida. In: BROCK, Colin; SCHWARTZMAN, Simon (Eds). Os desafios da educação no Brasil. Rio de Janeiro: Nova Fronteira, 2005. p. 275-304. Disponível em: <http://www.schwartzman.org.br/simon/desafios/9posgrado.pdf>. Acesso em: 28 jul. 2015.

BARBOSA, Denis Borges. A estrutura legal internacional dos direitos autorais. Palestra no Seminário de Propriedade Intelectual e Economia da Cultura que foi realizado em setembro de 2010 no Centro Cultural da Justiça Federal. Disponível em: < http://www.denisbarbosa.addr.com/ arquivos/200/propriedade /direito internacional_autoral.pdf>. Acesso em: 05 set. 2015.

BASSO, Maristela. O direito internacional da propriedade intelectual. Porto Alegre: Livraria do Advogado, 2000. 
BAUER, Martin; GASKELL, George (org.). Pesquisa qualitativa com texto, imagem e som. Petrópolis: Vozes, 2002.

BITTAR, Carlos Alberto. Direito de Autor. 3.ed. rev. ampl. e atual. Rio de Janeiro: Forense, 2001. p.12.

BITTAR, Carlos Alberto. Contornos atuais do direito do autor. Rio de Janeiro: Revista dos Tribunais, 1992.

BOBBIO, N. Política. In: BOBBIO, N.; MATEUCCI, N.; PASQUINO,G. Dicionário de Política. 12. ed. Brasília: Editora da UNB, 2002. v. 2.

BONAFONT, L.C. Redes de políticas públicas. Madri: Centro de investigaciones Sociológicas, 2004.

BRANCO, Sérgio; Britto, Walter. O que é creative commons? Novos modelos de direito autoral em um mundo mais criativo. Rio de Janeiro: FGV, 2013. 176 p.

BRASIL. Constituição da República Federativa do Brasil (1891). Disponível em: <http://www.planalto.gov.br/ccivil_03/constituicao/Constituicao91.htm>. Acesso em 18 set. 2010.

BRASIL. Constituição da República Federativa do Brasil (1988). Disponível em: < http://www.planalto.gov.br/ccivil 03/Constituicao/Constituicao.htm>. Acesso em 23 set. 2015

BRASIL. Lei 496 de agosto de 1898. Disponível em: <http://www.planalto.gov.br/ccivil_03/leis/l9610.htm>. Acesso em: 15 dez. 2013.

BRASIL. Lei $\mathbf{9 . 6 1 0}$ de fevereiro de 1998. Disponível em: <http://www.planalto.gov.br/ccivil_03/leis/l9610.htm>. Acesso em: 15 dez. 2013.

CABRAL, Plínio. As limitações ao direito autoral na Lei no 9.610. Revista da ABPI, São Paulo, n.37, nov./dez. 1998.

CABRAL, Plínio. Direito autoral: dúvidas e controvérsias. São Paulo: Habra, 2000. p.41-42.

CABRAL, Plínio. A nova lei de direitos autorais: comentários. 4. ed. São Paulo: Harbra, 2003.

COHEN, Madeline et. al. Speaking as one: supporting open access with departamental resolutions. Journal of librarianship and scholarly communication, Oregon, v.2, n.1, set. 2013.

CROW, Raym. The Case for Institutional Repositories: a SPARC position paper. Washington: $\quad$ SPARC, 2002. 27 p. Disponível em: < http://www.sparc.arl.org/sites/default/files/media files/instrepo.pdf>. Acesso em: 18 out. 2015.

CUNHA FILHO, Francisco Humberto. Direitos culturais como direitos fundamentais no ordenamento jurídico. Brasília: Brasília Jurídica, 2000, p. 92. 
DI PIETRO, Maria Sylvia Zanella. Direito Administrativo. 23 ed. São Paulo: Atlas, 2010.

DIAS, Maurício Cozer. Utilização musical e direito autoral. Campinas: Bookseller, 2000.

DUARTE, Eliane Cordeiro de Vasconcellos Garcia; PEREIRA, Edmeire Cristina. Direito autoral: perguntas e respostas. Curitiba, IFPR, 2009.

EBOLI, José Carlos de Camargo. Pequeno mosaico do direito autoral. São Paulo: Irmãos Vitole, 2007.

ESTADOS UNIDOS DA AMÉRICA. Copyright 1976 Act. Disponível em: <http://copyright.gov/title17/> Acesso em: 29 de mar. de 2015.

FRAGOSO, João Henrique da Rocha. Direito autoral: da antiguidade à internet. São Paulo: Quartier Latin, 2009.

FRIEND,Frederick. From toll access to Open Access: the concept and evolution of new models for research communication. In: RODRIGUES, Eloy; SWAN, Alma; BAPTISTA, Ana Alice (ed.). Uma década de acesso aberto da UMinho e no mundo. Braga: Publito, 2013.

GANDELMAN, Henrique. De Gutenberg à internet: direitos autorais na era digital. 4.ed. ampl. e atual. Rio de Janeiro: Record, 2001. p.32.

GARVEY, W. D., GRIFFITH, B. C. Communication and information process within scientific disciplines, empirical findings for psychology. In: GARVEY, W. D. Communication: the essence of science; facilitating information among librarians, scientists, engineers and students. Oxford: Pergamon, 1979. 332 p.

GARVEY, W. D; GRIFFITH, B. C. Scientific communication as a social system. Science, v.157, p. 1011-1016, 1967.

GIL, Gilberto. Disponível em: < http://www.agenciabrasil.gov.br/noticias /2006/12/12/ materia. 2006>.Acesso em: 15 set. 2010.

GLASER, Barney G; STRAUSS, Anselm L. The discovery of grounded theory: strategies for qualitative research. New York: Aldine de Gruyter, 1967.

HARNAD, Stevan. Fast-Forward on the green road to Open Access: the case against mixing up green and gold. Ariadne, n. 42 jan. 2005.

HURD,Julie M. Scientific communication: new roles and new players. Science \& Technology Libraries, v. 25, n. 1. 2004.

JOYCE, Craig et al. Copyright Law. 6. ed. LexisNexis. 2003.

KELSEN, Hans. Théorie Pure du Droit. 2.ed. Paris: [s.n], 1962.

KINGDON, J. Agendas, Alternatives and Public Policies. 2. ed. Longman Classics in Political Science. Boston: Longman, 2011. 
KVALE, S. Interviews: an introduction to qualitative research interviewing, Thousand Oaks. London: Sage, 1996.

LAMPREIA, Luiz Felipe Palmeia. Resultados da Rodada Uruguai: uma tentativa de síntese. Estudos avançados, São Paulo, v. 9, n.23, jan-abr. 1995.

LEITE, Eduardo Lycurgo. Direito de autor. Brasília: Brasília Jurídica, 2004.

LEITE, Fernando César Lima. Como gerenciar e ampliar a visibilidade da informação científica brasileira: repositórios institucionais de acesso aberto. Brasília: IBICT, 2009.

LEMOS, Ronaldo et al. Direitos autorais em reforma. Rio de Janeiro, FGV Direito Rio, 2011.

LEMOS, Ronaldo; BRANCO JÚNIOR, Sérgio Vieira. Copyleft , Software Livre e Creative Commons: nova feição dos direitos autorais e as obras colaborativas. 2007. Disponível em: <https://bibliotecadigital.fgv.br/ dspace/bitstream/handle/ 10438/2796/Copyleft Software Livre e CC A Nova\%20Feicao dos Direitos Autor ais e as Obras Colaborativas.pdf?sequence=1\&isAllowed=y> Acesso em: 10 out. 2015.

LESSIG, Lawrence. Cultura Livre: como a mídia usa a tecnologia e a lei para barrar a criação cultural e controlar a criatividade. Penguin Press HC. EUA. 2004.

LIMA, Clóvis Montenegro de; SANTINI, Rose Marie. Copyleft e licenças criativas de uso de informação na sociedade da informação. Ci. Inf., Brasília, v. 37, n. 1, p. 121128, abr. 2008. Disponível em:<http://www.scielo.br/scielo. php? script= sci_ arttext\&pid=S0100-19652008000100011\&lng=en\&nrm=iso>. Acesso em 17 out. 2015.

LYNCH, Clifford A. Institutional repositories: essential infrastructure for scholarship in the digital age, arl: a bimonthly report. Research Library Issues and actions from ARL, CNI, and SPARC, n. 226. 2003. Disponível em: <http://www.arl.org/newsltr/226/ir.html>. Acesso em 13 out. 2015.

MANSO, Eduardo J. Vieira. O que é direito autoral. São Paulo: Brasiliense, 1992. p.13. (Coleção Primeiros Passos, v.187).

MARTINS, Ricardo Marcondes. Efeitos e vícios do ato administrativo. São Paulo: Malheiros, 2008.

MEDAUAR, Odete. Direito administrativo moderno. 16.ed. rev. atual. e ampl. São Paulo: Revista dos Tribunais, 2012.

MELLO, Celso Antônio Bandeira de. Curso de direito administrativo. 17. ed. São Paulo: Malheiros, 2004. p. 352.

MENEZES, Elisangela Dias. Curso de direito autoral. São Paulo: Del Rey, 2007. 
MONIZ, Pedro de Paranaguá; CERDEIRA, Pablo de Camargo. Copyleft e software livre: uma opção pela razão: eficiências tecnológica, econômica e social. Revista da ABPI, n. 70, p. 65-69, maio/jun. 2004.

NORRIS, Michael; OPPENHHEIM, Charles; ROWLAND, Fytton. The citation advantage of open-access articles. Journal of the American Society for Information Science and Technology. v. 59, n. 12, p. 1963-1972, out. 2008.

OLIVEIRA, Ana Carolina Borges. Diferenças e semelhanças entre os sistemas da civil law e da common law. Constituição, Economia e Desenvolvimento: Revista da Academia Brasileira de Direito Constitucional. Curitiba, v. 6, n. 10, jan./jun. 2014, p. 43-68.

OLIVEIRA, Tânia Chalhun de. Acesso aberto à informação científica no Brasil: um estudo das universidades públicas do estado do Rio de Janeiro. 2011. 77 f. Relatório final (Pós-doutorado em Comunicação Científica) - MCTI/IBICT, Rio de Janeiro, 2011.

ORTELLADO, Pablo. As políticas nacionais de acesso aberto à comunicação científica. Liinc em Revista, Rio de Janeiro, v.4, n.2, set. 2008, p. 186-195. Disponível em: http://www.brapci.inf.br/ repositorio/2010/06/pdf eeae490ef8 0010 886.pdf>. Acesso em: 28 mar. 2015.

PARANAGUÁ, Pedro; BRANCO, Sérgio. Direitos autorais. Rio de Janeiro: FGV, 2009.

PRÍNCIPE, Pedro; et al. Políticas e mandatos de Acesso Aberto: percepções dos investigadores. ACTAS, n.11, 2012.

REESE, R. Anthony. Innocent Infringement in U.S. Copyright Law: a history. In: Columbia Journal of Law \& the Arts. 2007.

RODRIGUES, Eloy; SARAIVA, Ricardo. RepositóriUM: 10 anos de Acesso Aberto ao Conhecimento. In: RODRIGUES, Eloy; SWAN, Alma; BAPTISTA, Ana Alice (ed.). Uma década de acesso aberto da Uminho e no mundo. Braga: Publito, 2013.

ROHRMANN, carlos aberto. A proteção dos direitos autorais nos estados unidos em face da digitalização: o caso Napster. Revista da Faculdade de Direito Milton Campos, Belo Horizonte: vol. 8, 2001, p. 133-150.

SABATIER, P. A. An advocacy coalition framework of policy change and the role of policy-oriented learning therein. Policy Sciences, [S. I.], v. 21, 1988, p.129-168.

SABATIER, P. A; WEIBLE, C. M. The advocacy coalition framework: Innovations, and clarifications. In SABATIER, P.A.Theories of the Policy Process. 2. ed. Boulder: Westview Press, 2007. p. 189-220.

SANTOS, Manuela. Direito autoral na era digital: impactos, controvérsias e possíveis soluções. São Paulo: Saraiva, 2009.

SCHEUFEN, Marc. Copyright versus open access: on the organization and international political economy. Springer, 2014. 191 p. 
SECCHI, L. Políticas Públicas: Conceitos, esquemas, casos práticos. 2 ed. São Paulo: Cengage Learning. 2013.

SILVA, Almiro Couto et al. Notas sobre o conceito de ato administrativo. Rio de Janeiro: Lumen Juris, 2006. p. 277.

SILVA, Teresinha Elisabeth da; ALCARÁ, Adriana Rosecler. Acceso aberto a La informatión científica: politicas e iniciativas governamentales. Inf. Inf., Londrina, v.14, n.2, p.100-116, jul./dez. 2009.

SILVEIRA, Newton. A propriedade intelectual e a nova lei da propriedade industrial. São Paulo: Saraiva, 1996. p.14-15.

SOUTO, Patrícia Cristina Nascimento; OPPENHEIM, Charles. Direitos autorais e o movimento de acesso aberto: um equilíbrio que demanda novas atitudes. In: FERREIRA, Sueli Mara Soares Pinto; TARGINO, Maria das Graças (Orgs.). Mais sobre revistas científicas. São Paulo: Cengage Learning, 2008.

SOUZA, Carlos Fernando Mathias de. Direito autoral. 2. ed. rev. Brasília: Brasília Jurídica, 2003.

SOUZA, Celina. Políticas públicas: uma revisão de literatura. Sociologias, Porto Alegre, ano 8, nº 16, jul.-dez., 2006, p. 20-45.

STANDLER, Ronald B. Moral rights of authors in the USA. Abr. 2012. Disponível em; < http://www.rbs2.com/moral.pdf> Acesso em 10 set. 2015.

STRASSMANN, Paul A. The politics of information management: policy guidelines. Connecticut: Information Economics Press, 1994.

SUBER,Peter. Open Access. Cambridge: MIT Press, 2012.

TOMAÉL, Maria Inês; SILVA, Teresinha Elisabeth da. Repositórios institucionais: diretrizes para política de informação. In: ENCONTRO NACIONAL DE PESQUISA EM CIÊNCIA DA INFORMAÇÃO, 8, 2007, Salvador. Disponível em: $<$ http://www.enancib.ppgci.ufba.br/artigos/GT5--142.pdf>. Acesso em: 18 jan. 2015

TRIDENTE, Alessandra. Direito autoral: paradoxos e contribuições para a revisão da tecnologia jurídica no século XXI. Rio de Janeiro: Elsevier, 2009, p. 28.

WEIBLE, C.M; SABATIER, P.A. Coalitions, science, and belief change: Comparing adversarial and collaborative policy subsystems. The Policy Studies Journal, v.37, n. 2, 2009.

WEIBLE, Cristopher M.; SABATIER, Paul A. Comparing Policy Networks: Marine Protected Areas in California. The Policy Studies Journal, Malden, v. 33, n. 2, 2005, p. 181-201.

XIA, J. et al. A review of open access self-archiving mandate policies. Libraries and the Academy, v. 12, n. 1, jan. 2012, p. 85-102. 
ZAHARIADIS, N. The Multiple Streams Framework: Structure, limitations, prospects. In: SABATIER, P. (org.) Theories of the Policy Process. Boulder, CO, Westview Press, $2^{\mathrm{a}}$ ed., 2007, p. 65-92.

ZANINI, Leonardo Estevam de Assis. A proteção internacional do direito de autor e o embate entre os sistemas do copyright e do droit d'auteur. Rev. SJRJ, Rio de Janeiro, v. 18, n. 30, abr. 2011, p. 115-130. 


\section{APÊNDICE A - Roteiro das entrevistas}

1) Qual foi o trâmite/negociações realizadas para a proposição da Política?

2) Qual foi a participação dos docentes e discentes na elaboração e discussão da política e como isso influenciou na questão do povoamento do repositório institucional?

3) Qual tem sido a reação da comunidade acadêmica com relação à exigência do depósito compulsório? Qual foi o grau de aceitação dos membros?

4) Qual o tipo de suporte que a universidade/biblioteca oferece ao autor?

5) Quais são os fatores que contribuem ou não para o sucesso da política de direitos autorais? 


\section{APÊNDICE B - Instituições selecionadas no ROARMAP}

$\begin{array}{ll}\text { FURG } & \text { Fundação Universidade Federal do Rio Grande } \\ \text { UnB } & \text { Universidade de Brasília } \\ \text { USP } & \text { Universidade de São Paulo } \\ \text { UFBA } & \text { Universidade Federal da Bahia } \\ \text { UFCE } & \text { Universidade Federal do Ceará } \\ \text { UFLA } & \text { Universidade Federal de Lavras } \\ \text { UFOP } & \text { Universidade Federal de Ouro Preto } \\ \text { UFRB } & \text { Universidade Federal do Recôncavo da Bahia } \\ \text { UFRN } & \text { Universidade Federal do Rio Grande do Norte } \\ \text { UFRGS } & \text { Universidade Federal do Rio Grande do Sul } \\ \text { UFS } & \text { Universidade Federal de Sergipe }\end{array}$

